$\operatorname{lo}^{\infty}$

ARGONNE NATIONAL LABORATORY

P. O. Box 299

Lemont, Illinois

\title{
INTERFACIAL AREA IN LIQUID-LIQUID DISPERSIONS RELATED TO \\ FLUID MOTION IN MIXING VESSELS
}

by

Walton A. Rodger

Chemical Engineering Division

June, 1956

Submitted in Partial Fulfillment of the

Requirements for the Degree of Doctor of Philosophy

With Major Studies in Chemical Engineering

in the Graduate School of Illinois Institute of Technology

Operated by The University of Chicago

under

Contract $W-31-109-e n g-38$ 


\section{DISCLAIMER}

This report was prepared as an account of work sponsored by an agency of the United States Government. Neither the United States Government nor any agency Thereof, nor any of their employees, makes any warranty, express or implied, or assumes any legal liability or responsibility for the accuracy, completeness, or usefulness of any information, apparatus, product, or process disclosed, or represents that its use would not infringe privately owned rights. Reference herein to any specific commercial product, process, or service by trade name, trademark, manufacturer, or otherwise does not necessarily constitute or imply its endorsement, recommendation, or favoring by the United States Government or any agency thereof. The views and opinions of authors expressed herein do not necessarily state or reflect those of the United States Government or any agency thereof. 


\section{DISCLAIMER}

Portions of this document may be illegible in electronic image products. Images are produced from the best available original document. 
ACKNOWLEDGEMENT ...................... v

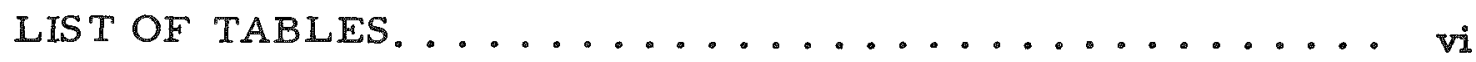

LIST OF ILLUSTRATIONS .................... vii

LIST OF NOMENCLATURE ................. ix

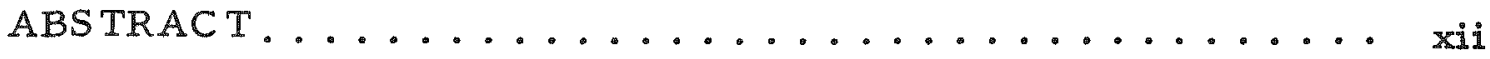

CHAPTER

I. INTRODUCTION ................... 1

Statement of Problem

Importance of the Investigation

Previous Work

II. EXPERIMENTAL EQUIPMENT ............ 6

Mixing Vessels

Impeller Drive

Light Source and Detector

III. MEASUREMENT OF INTERFACIAL AREA ......

Previous Work

Theory

Experimental

Correlation of Transmittance Data

Reproducibility of Data

IV. EXPERIMENTAL PROCEDURES ......... 35

Control of Contamination

Equilibration

Method of Obtaining Data

Measurement of Physical Properties

V. EXPERIMENTAL RESULTS............. 43

Systems Studied and Results

Correlation of Data 
The author would like to express his appreciation to numerous colleagues in the Chemical Engineering Division for their support and encouragement during the course of this work, in particular to:

Dr. S. Lawroski and Dr. J. H. Rushton for valuable counsel and criticism;

Virgil G. Trice, Jr. who is responsible for most of the work on the correlation of light transmission and interfacial area;

Lester F. Dorsey and Donald K. Fleming who aided in obtaining much of the data. 


\section{LIST OF TABLES}

1. Glass Bead Test for Accuracy and Precision of Photographic Method for Measuring

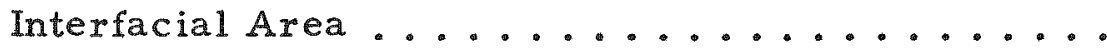

2. Physical Properties of Systems Studied ...........

3. Summary of Effects Predicted by Generalized Correlation of Data .............

4. Area and Settling Time Data Obtained in

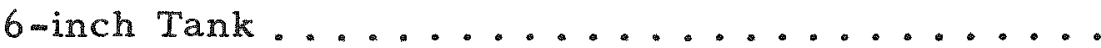

5. Area and Settling Time Data Obtained in 12 -inch Tank

6. Area and Settling Time Data Obtained in

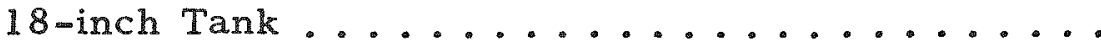

7. Light Transmittance Data Obtained in

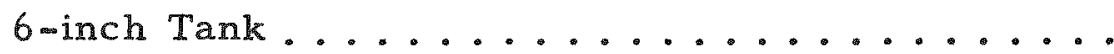

8. Light Transmittance Data Obtained in

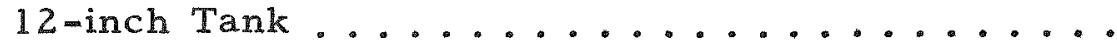

9. Light Transmittance Data Obtained in 18-inch Tank

10. Parameters Used in Correlation .............

11. Data Illustrative of Effect of Contamination on Settling Time and Interfacial Area ......... 


\section{LIST OF ILLUSTRA TIONS}

Figure

Page

1. Assembly Drawing of 6 -inch Mixing Vesse1 ........ 7

2. Turbine Dimensions .................... 8

3. Six-inch Experimental Mixing Vessel ........... 9

4. Schematic Diagram of Light Source ........... 12

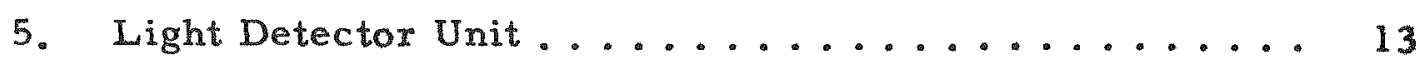

6. Wave Length Distribution of Filtered Light

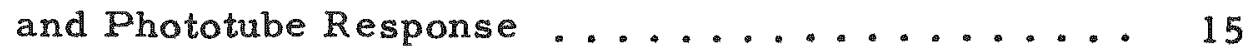

7. Circuit Diagram of Equipment Used to Measure

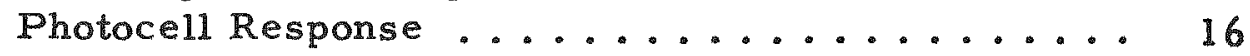

8. Photograph of Experimental Equipment .......... 17

9. Typical Photograph of Dispersion ............ 24

10. Comparison of Calculated Size Frequency of Dispersed Glass Beads with Measured

Values Obtained by Several Observers ........

11. Correlation (D) of Light Transmittance with

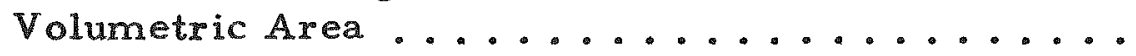

12. Correlation (B) of Light Transmittance with

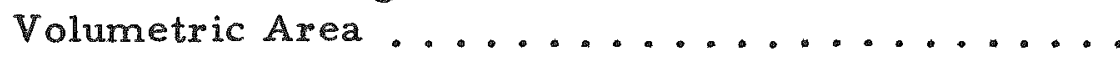

13. Scattering Factor, $\alpha$, as a Function of the

Relative Specific Refraction, $M$

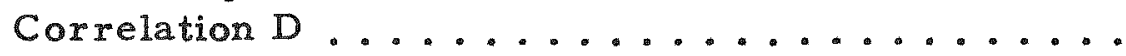

14. Scattering Factor, $\alpha$, as a Function of the

Relative Specific Refraction, $M$

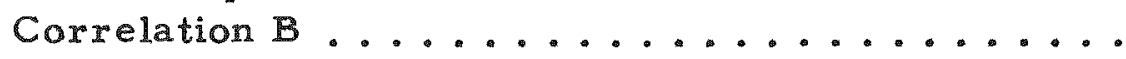

15. Illustration of Types of Coalescence............40

16. Equipment Used to Obtain Interfacial Tension ...... 42

17. Illustrative Presentation of Data, Da vs

Weber Number, System: Xylene-Water ......... 


\section{LIST OF ILLUSTRATIONS (Continued)}

Figure

Page

18. Variation of $\mathrm{D} / \mathrm{T}$ Dependence with Mean

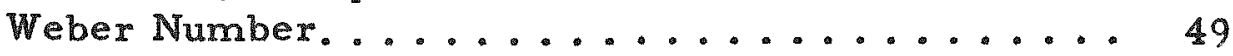

19. Illustrative Scale-up Data ................ 51

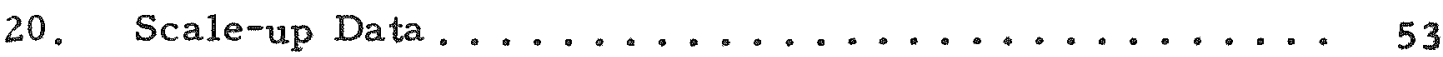

21. Generalized Correlation of Interfacial Area with Weber Number ................. 54

22. Simplified Correlation of Interfacial Area with Weber Number ................... 55

23. Photograph of $W / O$ Dispersion .............. 68 


\section{LIST OF NOMENCLATURE}

\begin{tabular}{|c|c|}
\hline$\frac{\text { Roman }}{\text { Capital Letters }}$ & \\
\hline A & Area through which jet flow of impeller is operative \\
\hline $\mathrm{D}$ & Impeller diameter \\
\hline$H$ & Head produced by impeller \\
\hline I & Emergent light intensity \\
\hline$I_{0}$ & Incident light intensity \\
\hline $\mathbf{K}$ & Proportionality constant \\
\hline $\mathbb{K}_{\mathrm{s}}$ & Scattering area coefficient \\
\hline $\mathbf{L}$ & Optical path length \\
\hline $\mathrm{M}$ & Relative specific refraction of drop (Lorentz Coefficient) \\
\hline $\mathbf{N}$ & Impeller speed \\
\hline $\mathbb{N}_{i}$ & Number of drops in interval \\
\hline$O / W$ & Oil-in=water \\
\hline Q & Volumetric flow produced by impeller \\
\hline S & Scattering cross section \\
\hline $\mathbf{T}$ & Tank diameter \\
\hline $\mathbf{T}_{0}$ & Reference tank diameter ( 6 inches) \\
\hline W & Width of impeller blade \\
\hline $\mathrm{W} / \mathrm{O}$ & Water-in-oil \\
\hline
\end{tabular}


LIST OF NOMENCLATURE (Continued)

Roman Lower

Case letters

a

Interfacial area per unit volume

d

Drop diameter

$\mathrm{d}_{\mathrm{i}}$

Drop diameter in interval, i

$d_{\text {sV }}$

Mean surface-volume or Sauter drop diameter

1

Volume fraction dispersed phase

g

Acceleration due to gravity

k

Exponent on $D / T$ ratio, a function of the Webex number

$\mathrm{m}$

Relative refractive index of drop to field phase

n

Number of drops per unit volume of total mixed phase

t

Settling time

to

Reference settling time ( 1 minute)

u

Linear velocity of flow produced by impeller 
LIST OF NOMENCLATURE (Continued)

Greek Letters

$\begin{array}{ll}\alpha_{\beta} \beta & \text { Optical parameters } \\ \Delta_{\rho} & \text { Density difference of phases } \\ \mu_{\mathrm{D}} & \text { Viscosity of dispersed phase } \\ \mu_{\mathrm{F}} & \text { Viscosity of continuous or field phase } \\ \nu_{\mathrm{D}} & \text { Kinematic viscosity of dispersed phase } \\ \nu_{\mathrm{F}} & \text { Kinematic viscosity of field phase } \\ \pi_{\mathrm{i}} & \text { Dimensionless group } \\ \rho_{\mathrm{D}} & \text { Density of dispersed phase } \\ \rho_{\mathrm{F}} & \text { Density of field phase } \\ \sigma_{i} & \text { Interfacial tension } \\ \phi & \text { Scale-up function }\end{array}$




\section{ABSTRACT}

In this investigation a study was made of interfacial area produced in liquid-liquid systems in baffled cylindrical mixing vessels by the action of turbine impellers.

The study was limited to consideration of $\mathrm{O} / \mathrm{W}$ dispersions. In all cases the liquid height was set equal to the vessel diameter and equal volumes of the two phases were used. The impellers used were six-blade flat-blade turbines.

Two methods of measuring interfacial area of $O / W$ dispersions are presented - one photographic and the other making use of a correlation between light transmittance and interfacial area. The interfacial area-light transmittance method is described and its precision and accuracy established. This correlation was used to make interfacial area determinations on 17 systems the physical properties of which covered a wide range. Data were obtained for all systems in a 6-inch vessel and for four systems in 12 - and 18-inch vessels also. A variety of impeller sizes and speeds were employed.

The data obtained were correlated empirically as a complex function of the Weber number. The average deviation of the correlation is shown to be equivalent to that of the light transmittance-area correlation. The predicted effects of geometric and physical variables are shown to be logical.

Observations on the inversion of $O / W$ to $w / O$ dispersions are made and the effect of this inversion on dispersion settling time noted. 
CHAPTER I

INTRODUCTION

Statement of Problem

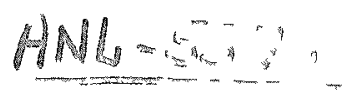

It is the object of this investigation to obtain a measure of the amount of interfacial area created between two immiscible liquids when they are brought into contact with one another by the action of an im peller in a mixing vessel. The problem is the outgrowth of an abortive attempt some three years ago to make a choice between possible solvents for a mixer-settler solvent extraction system based upon the settling time of dispersions. The simple experiments set up at that time served only to indicate the complexity of the problem and to kindle an interest in a more definitive approach to the problems of creation and destruction of interfacial area in liquid-liquid systems.

Accordingly there was set up at Argonne National Laboratory a three-part program:

1) to obtain accurate measurements of interfacial area,

2) to attempt to find a correlation of interfacial area and/or settling time with the physical properties of the system and with the size of the system and the input of energy into it, and

3) to use the information obtained in (1) and (2) to study mass transfer, separating the effects of film resistance and transfer area.

The first of these objectives has been met and a portion of the results published. $(35,36) \%$ This report deals with the first two phases of * Superscript numbers refer to bibliography at end of thesis. 
the problem. Work is well under way in the Chemical Engineering Division of Argonne National Laboratory on the third.

It became evident early in the study of this problem that there were so many possible variables that some simplification would be necessary if any degree of order were to be obtained in finite time. Consequently the second phase of the work has been confined to the following:

1) Dispersions were created in cylindrical mixing vessels and the liquid height was set equal to the vessel diameter.

2) The vessels had "standard baffles" and the impellers used were six-blade flat-blade turbines the dimensional ratios of which were those suggested by Rushton, et al.(28) Principles of dimensional similarity were observed through the investigation.

3) Equal volumes of each phase were used and the impeller was located centrally and at the interface of the two liquids.

4) All dispersions studied were oil-in-water $(O / W)$. Importance of the Investigation

Solvent extraction is a diffusional process and the amount of mass transferred per unit time is dependent upon the driving force, the resistance to transfer, and the effective interfacial area, a. The study of mass transfer in solvent extraction has been greatly hampered by the inability to measure the effective interfacial area except in a few very special cases (e.g. wetted wall columns, single drop experiments, two immiscible phases stirred gently so as not to disturb the interface). 
It has been customary, therefore, to lump together the effects of film resistance and interfacial area into a single term generally referred to as $\mathrm{ka}$ where a is the area per unit volume. The interaction of a multiplicity of variables upon this combined group is so complex that little headway has been made in obtaining generalized correlations of mass transfer based upon physical properties. The ability to measure interfacial areas under conditions of practical process significance is of importance because it will permit the independent study of the effects of area and resistance.

Direct measurement of area requires that equipment be built specifically to allow the measurements to be made. In many cases this is difficult or impossible. The work reported herein permits the direct estimation of interfacial area for one important process configuration over a wide range of physical properties and the useful range of energy inputs.

Previous Work

While there exists in the literature much information concerning stable or relatively stable emulsions, very little work has been done on temporary liquid-liquid dispersions of the type of interest in solvent extraction processes. Stable emulsions generally are characterized by a low volume fraction of dispersed phase and drop sizes of the order of $1 \mu_{0}(8)$ In these sizes the effect of electric charge on the particle or "zeta potential" is of importance. $(21,37)$ The effect of the zeta potential falls off rapidly with increasing size and it has been shown (25) that at 
droplet sizes of $50 \mu$ it is negligible. Since no drops less than $50 \mu$ were found in this investigation, the effect of zeta potential has been neglected and, in fact, data obtained on stable emulsions of small particle size are not considered pertinent in this work.

A recent publication by Langlois etal.(19) reports on work similar to that reported herein which has been going on independently at the University of California. The results of Langlois' work are compared with these in the Discussion of Data section. It is felt that Langlois' data are questionable for several reasons. The light probe used to measure interfacial area interfered too much with the mixing pattern in the tank and permitted local coalescence in the area where light transmission readings were taken. The photographs upon which the correlation was based are very poor and could not have yielded accurate data. The light transmission correlation used was of the form

$$
\frac{I_{0}}{I}=1+\beta a \text {. }
$$

This form cannot be supported upon any theoretical grounds. Rather some form of the Beer-Lambert relationship

$$
\ln \frac{\mathbb{I}_{0}}{I}=\alpha_{\mathrm{a}}
$$

would be expected and is, in fact, found in the work reported herein. Finally Langlois' light data had an average deviation of about 20 per cent. His attempts to correlate mixing data in a general form resulted in maximum deviations of as much as 300 per cent. 
Kessie, (15) in an investigation of dispersions caused by turbulence in pipes, showed a correlation of light transmission with inter facial area as an exponential function. The dispersions studied were about 2 per cent by volume oil in water. Dyes were added to the oil in quantity sufficient to make the oil droplets nearly completely opaque. A number of investigators $(6,31,33,34)$ have studied the breakup of liquid drops under defined conditions of flow. Much of this work has been in laminar flow and in all cases the effect of coalescence has been eliminated or at least minimized. Hinze(14) has presented an excellent analytical analysis of the hydrodynamic mechanisms of the splitting of liquid drops under a number of assumed flow fields.

Attempts to study the settling time or "break time" of liquidliquid dispersions were made by Bernstein, (2) Hernandez-Fragoso, (13) Flynn, (7) Oldshue, (22) and Christian.(4) Each of these studied the separation time of immiscible liquids in systems similar to that reported herein. All reported a phenomenon called "critical speed" being an impeller speed above which the break or separation time decreased markedly. Hernandez-Fragoso suggested the zeta potential as an explanation. Only Christian noted a phase inversion and he states that the phase inversion and break time were not coincident. His data appear to indicate otherwise, however. The phenomenon of "critical speed" was noted many times in the work reported herein and it was uniformly accompanied by an inversion of phases. 
The experimental equipment used in this investigation consisted of:

1) three mixing vessels, 6-, 12-, and 18-inches nominal diameter fitted with baffles and a variety of 6 -blade, flat-blade turbine impellers,

2) a controlled variable-speed drive for the impellers,

3) a light source and detector unit for the indirect measurement of interfacial area.

Mixing Vessels

The three mixing vessels were made of glass. An assembly drawing of the 6 -inch vessel is shown in Figure 1 . Brass flanges, teflon gaskets, and several tie rods were used to assemble the units. The 12and 18-inch vessels were similarly made.

The three vessels had inside diameters of $5-9 / 16,11-3 / 8$, and 17-3/8 inches respectively. Each had a set of four removable stainless steel baffles which extended above the expected liquid surface and were one-tenth the diameter of the vessel in width. Each vessel could be fitted with 6-blade, flat-blade turbines of various diameters, made of stainless steel. The relative dimensions of these impellers which follow the suggestions of Rushton et al., (28) are shown in Figure 2. These dimensions were chosen so that existing mixing power data could be used in conjunction with this work if desired. A picture of the assembled 6-inch vessel is shown in Figure 3. 

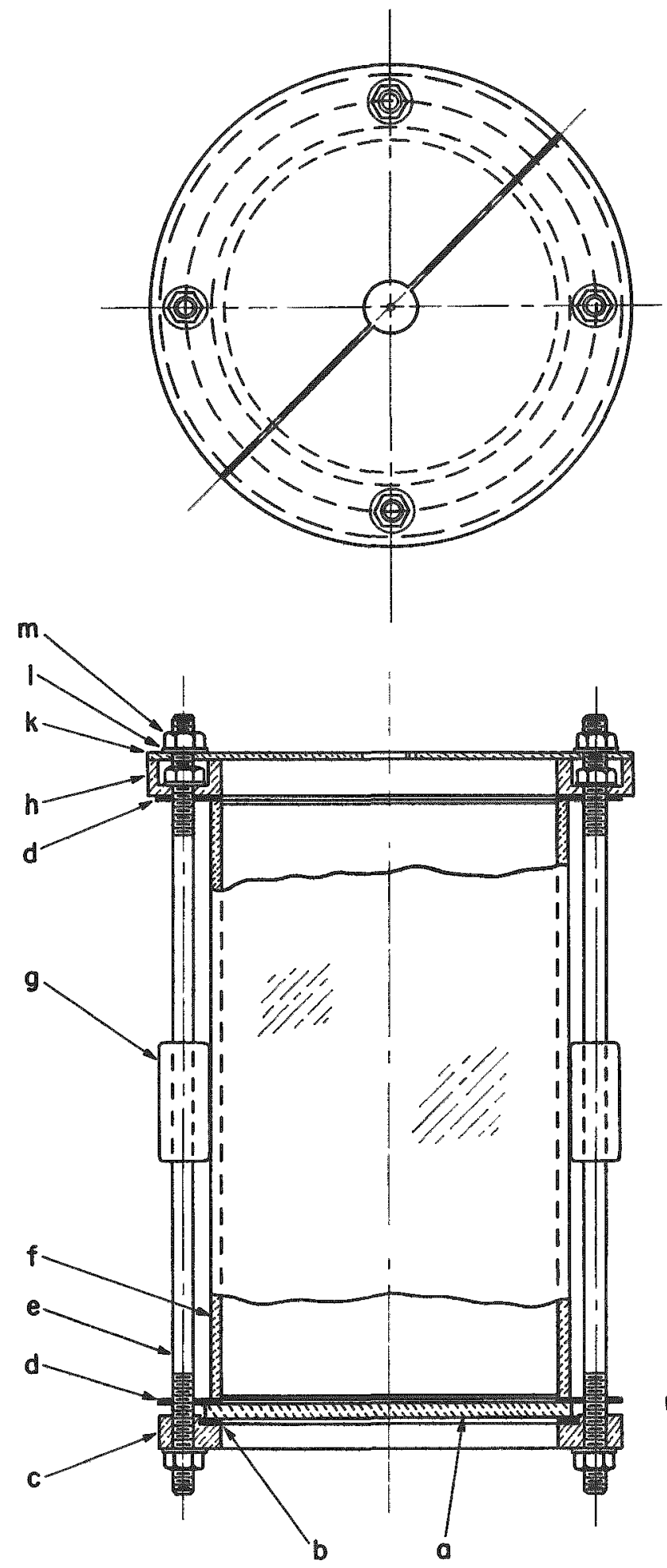

a. Water-white Plate Glass, $6 \frac{1}{8 \pm 1 / 32}$ inch OD by $1 / 4$ inch Thick

b. Neoprene Gasket, $6 \frac{1}{8}$ inch $O D$, $5 \%$ inch ID by $1 / 8$ inch Thick

c. Brass Flange

d. Tefion Gasket

e. 4 Steel Tierods $13^{1 / 4}$ inch Long by $3 / 8$ inch Diameter, Threoded Both Ends

f. Pyrex Cylinder 6 inch $O D$ by $3 / 16$ inch Minimum Wall by $101 / 8$ inch Long

g. Rubber Snubber

h. Brass Flange

k. Lucite Cover Plate

1. Lock Washers $3 / 8$ inch Std

m. Nuts, $3 / 8-16$ NC Hex Head

Fig. 1. Assembly Drawing of 6-inch Mixing Vessel 

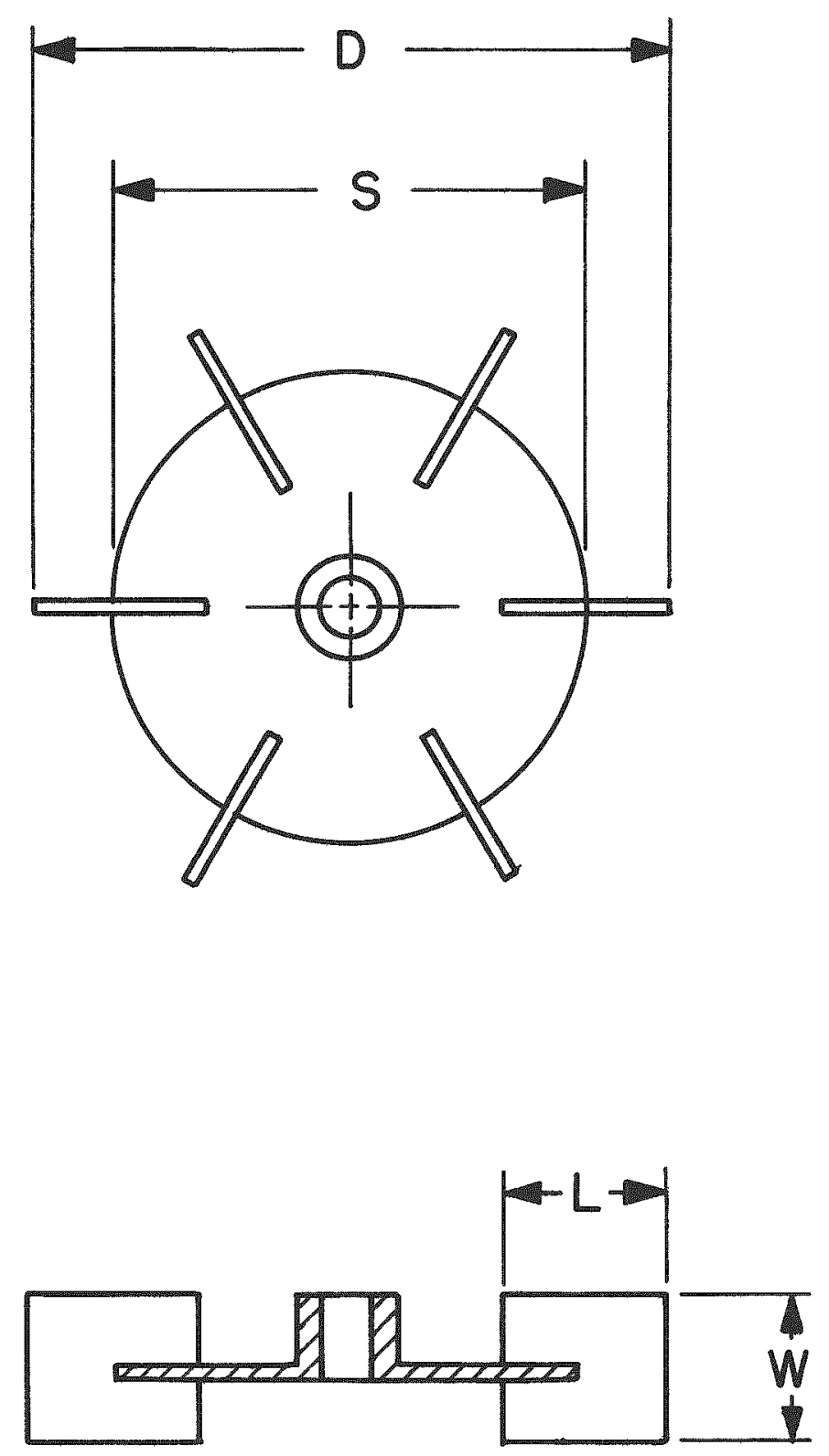

$D: S: L: W=20: 15: 5: 4$

Fig. 2. Turbine Dimensions 


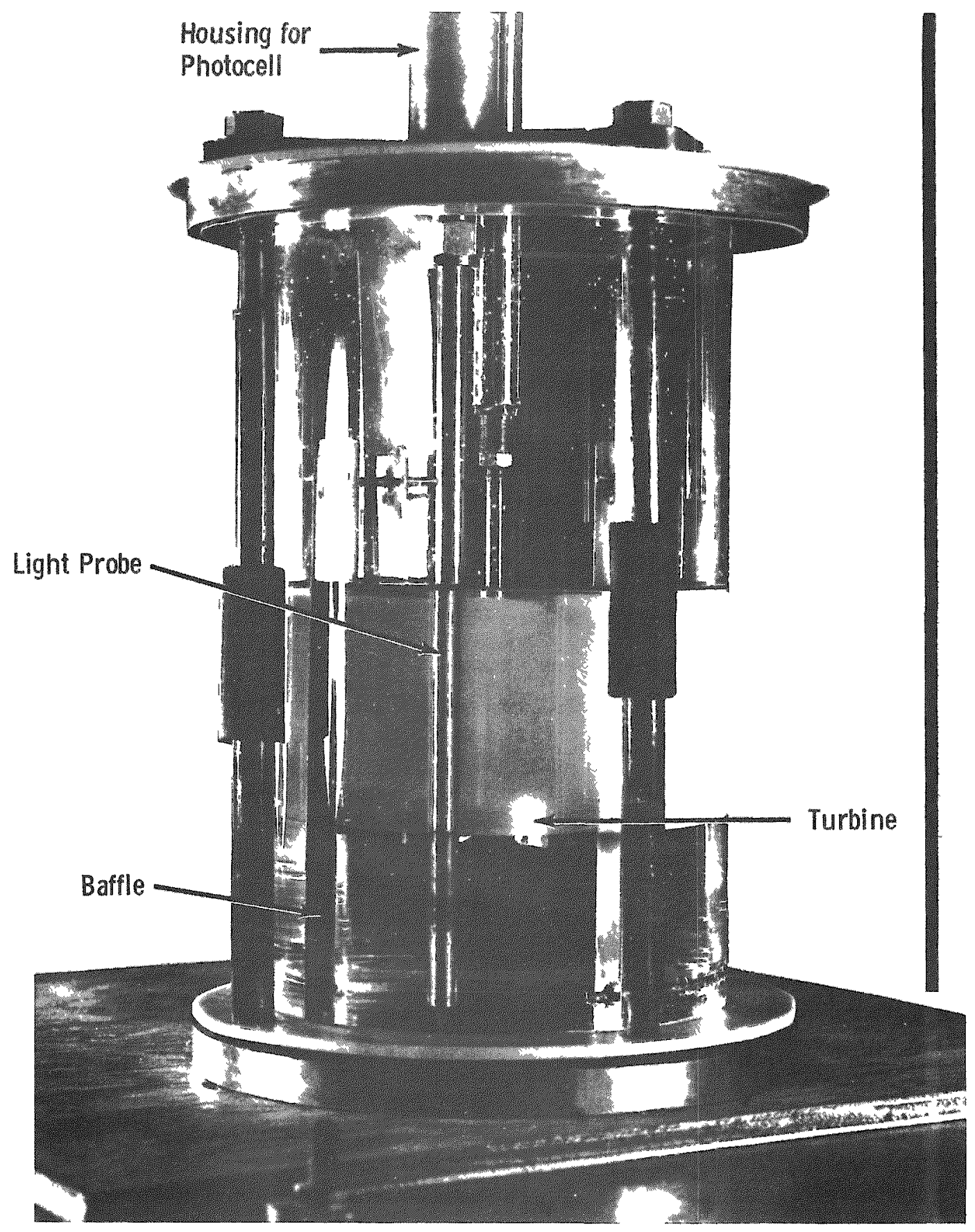

Light Source (not shown) is located below the vessel

Fig 3 Experimental Mixing Vessel 
The desired vessel was mounted on a platform affixed to the movable bed of a drill press. This permitted easy interchange and positioning of the impellers.

Impellex Drive

Mounted on a balcony above the mixing vessel was a $1 / 3 \mathrm{HP}$ motor with a drive shaft extending down into the vessel. The shaft speed was controlled by a General Electric Thy-Mo-Trol unit model number GEI-27470. The variable control resistance with which the unit was fitted was replaced with a set fixed resistances and a decade selector switch. This permitted the reproduction of eleven impeller speeds from 0.5 to $18 \mathrm{rps}$.

Light Source and Detector

The equipment required for light transmittance measurements consisted of three major components: a light source to provide a uniform, collimated beam; a sensitive light detector unit; and an electronic circuit to measure the amplified output of the detector unit. In the design of the equipment, ruggedness and reproducibility were of prime importance. Also of concern was the desire to mount as much of the equipment as possible external to the mixing vessel to minimize contamination of the liquids and interference of the normal flow pattexn.

Both the light source and detector were externally located. The light source was located below and the detector above the mixing vessel. A light pipe or probe extended down from the detector into the dispersion. The distance from the bottom of the vessel to the end of the light pipe determined the optical path. 
The light source used was a Universal Microscope Illuminator, No. 353, made by the American Optical Company and fitted with a sixvolt automobile bulb. During the course of the work improvements were made in the light source and detector. Therefore two correlations were required which are presented in the next chapter. For the first of these, Correlation $D$, the light leaving the microscope lamp was collimated by the use of an 18-mm aperture. The light was filtered through

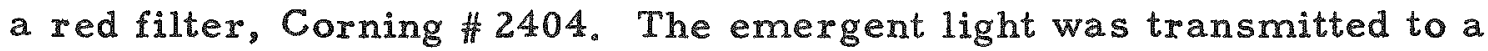
photocell by a glass sensing probe extending into the dispersion. The probe was a 30-cm, 3/8-inch diameter Pyrex 7740 platinum-coated glass rod polished on both ends. The liquid gap between the glass bottom of the vessel and the lower end of the probe (i.e. the light path, L) was adjustable. Data used in determining the light correlations were taken at values of $L$ of $1.0,1.5$, and $2.0 \mathrm{~cm}$. The data used in this work were taken at a light path of $1.5 \mathrm{~cm}$.

Later a collimating lens was added to the light source (see Figure 4) and an optical seal was made between the upper end of the glass sensing probe and the photocell using Dow Corning No. 200 silicone oil and a short section of black, 3/8-inch rubber tubing to cover the joint. This arrangement resulted in a somewhat more satisfactory correlation referred to herein as Correlation B (also see next chapter).

The detector unit is shown in Figure 5. It was found that more reproducible readings were obtained if the sides of the probe were protected from stray light by a platinum mirror finish. The mirror finish 


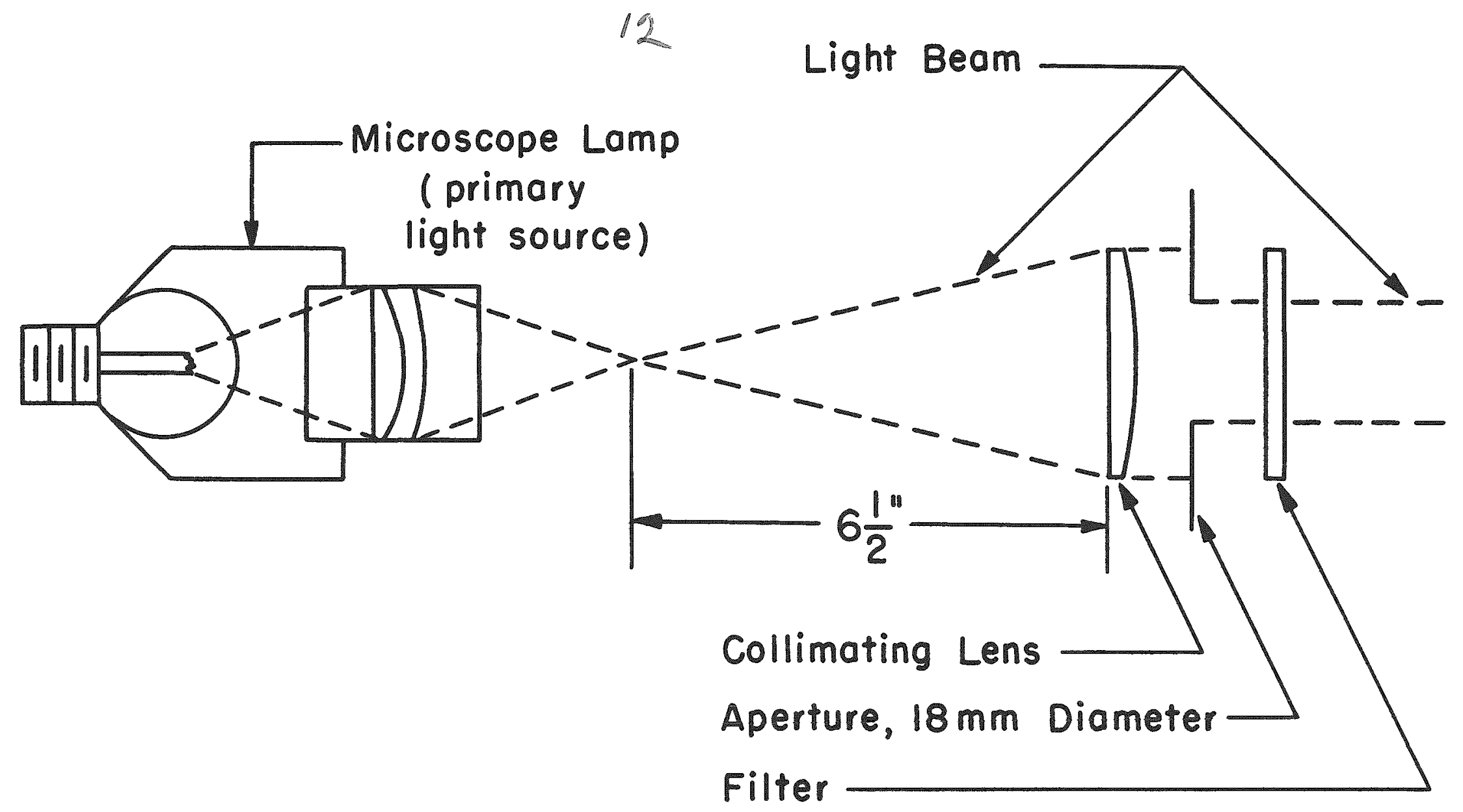

Fig. 4 Schematic Diagram of Light Source 

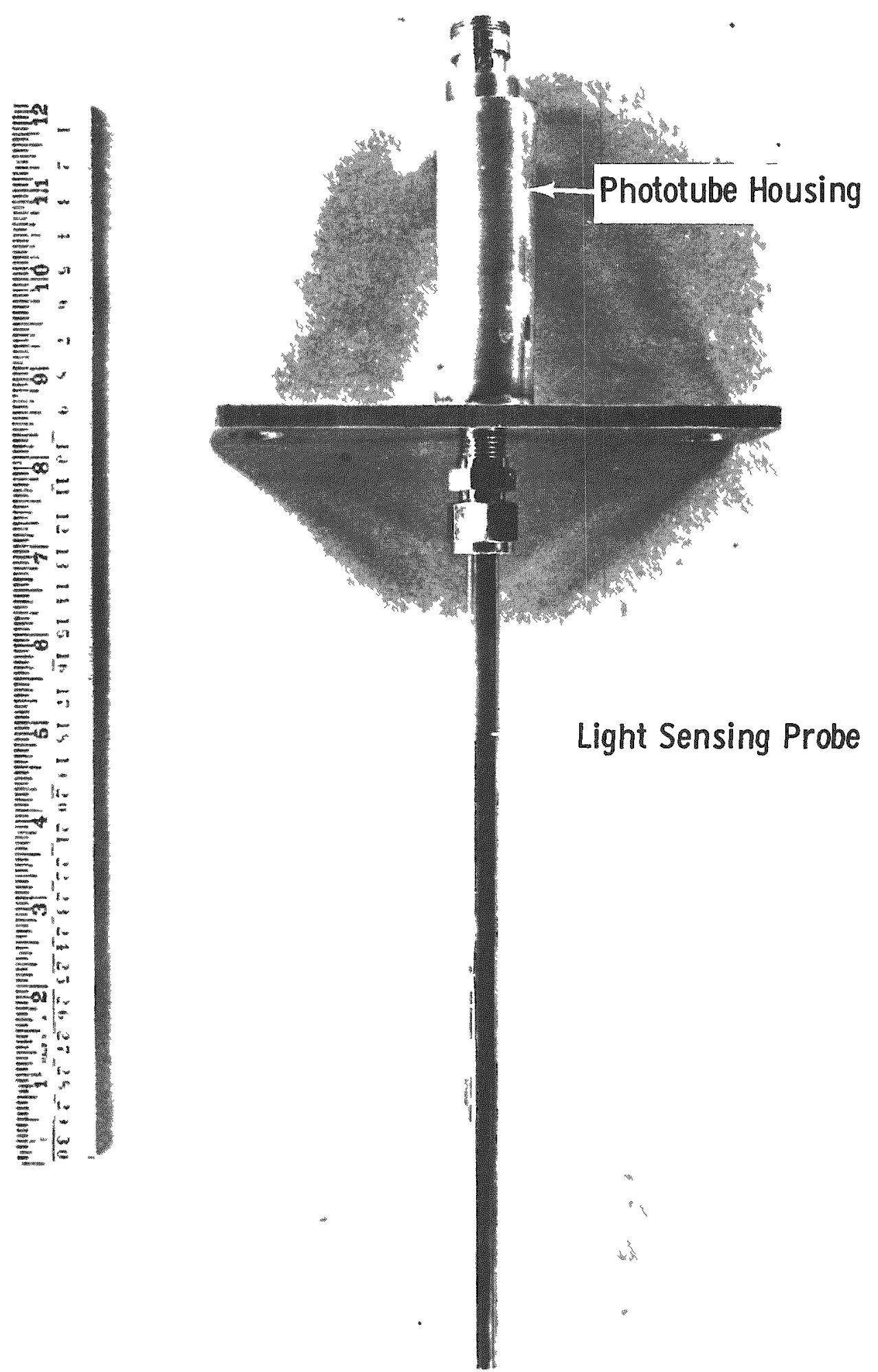

Fig. 5. Light Detector Unit 
was obtained by painting the cleaned rod with a thin coat of "Liquid Bright Platinum No. 05, Hanovia Chemical and Manufacturing Company, then heating to dull cherry red to produce the bright finish. The several probes made in this manner gave reproducible results. Overheating resulted in a dull finish which gave inconsistent readings.

An end-type photoelectric cell, RCA IP41, was used to give a better optical seal than that obtainable from side entrytypes. A vacuum tube was used in preference to a gas type, as the linearity of response was better. The IP4l tube, together with the red filter, responded in the near infra-red range as shown in Figure 6.

The output of the photocell was amplified and measured by balancing against a constant voltage with a calibrated helipot resistance. Since the photocell had a linear response, the resistance required was a measure of the light energy reaching the photocell and was used in calculations without conversion since ratios of light energy are involved. The circuit used is shown in Figure 7 .

A photograph of the entire equipment set up is shown in Figure 8. 


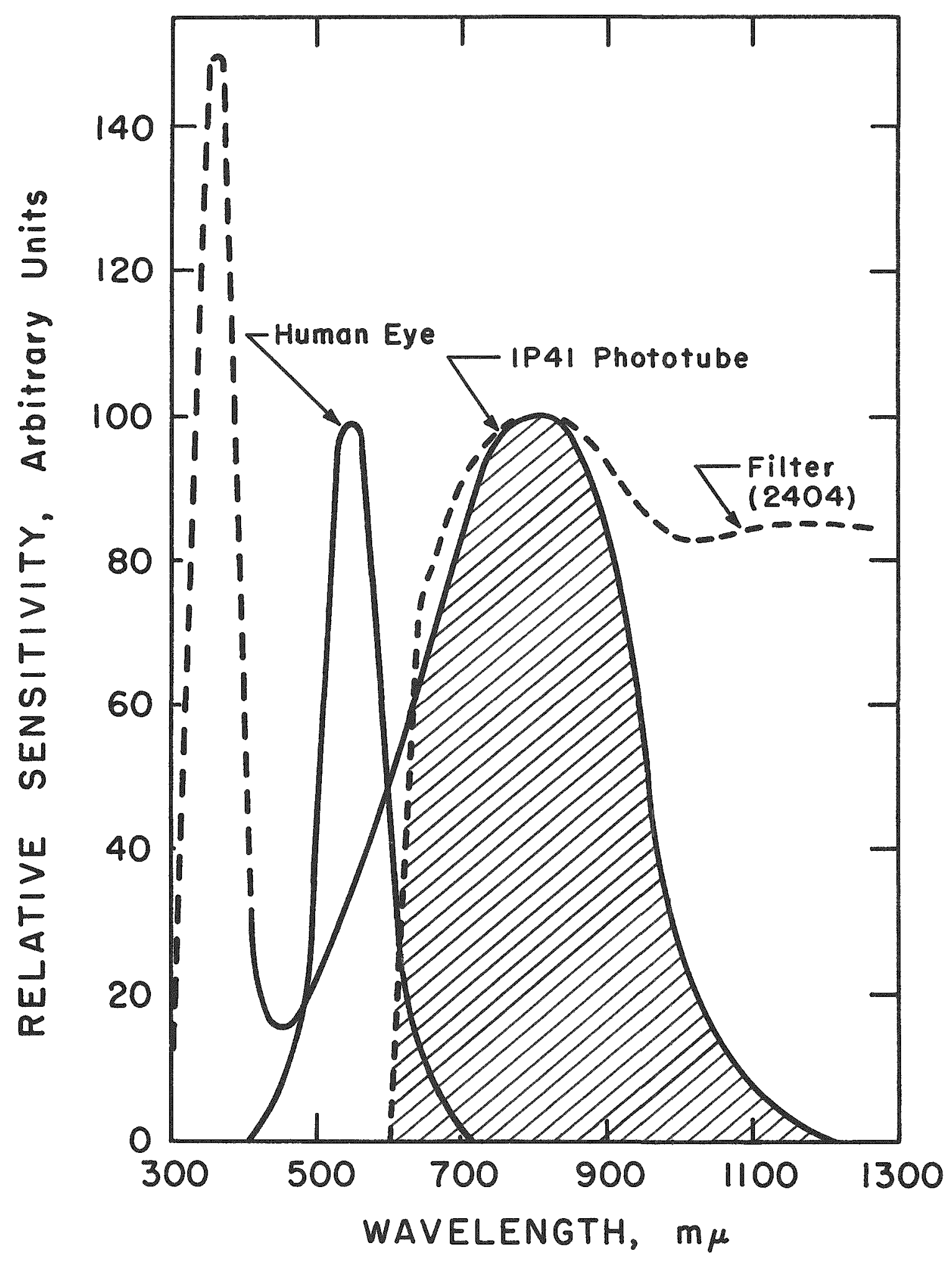

Fig. 6. Wavelength Distribution of Filtered Light and Phototube Response 


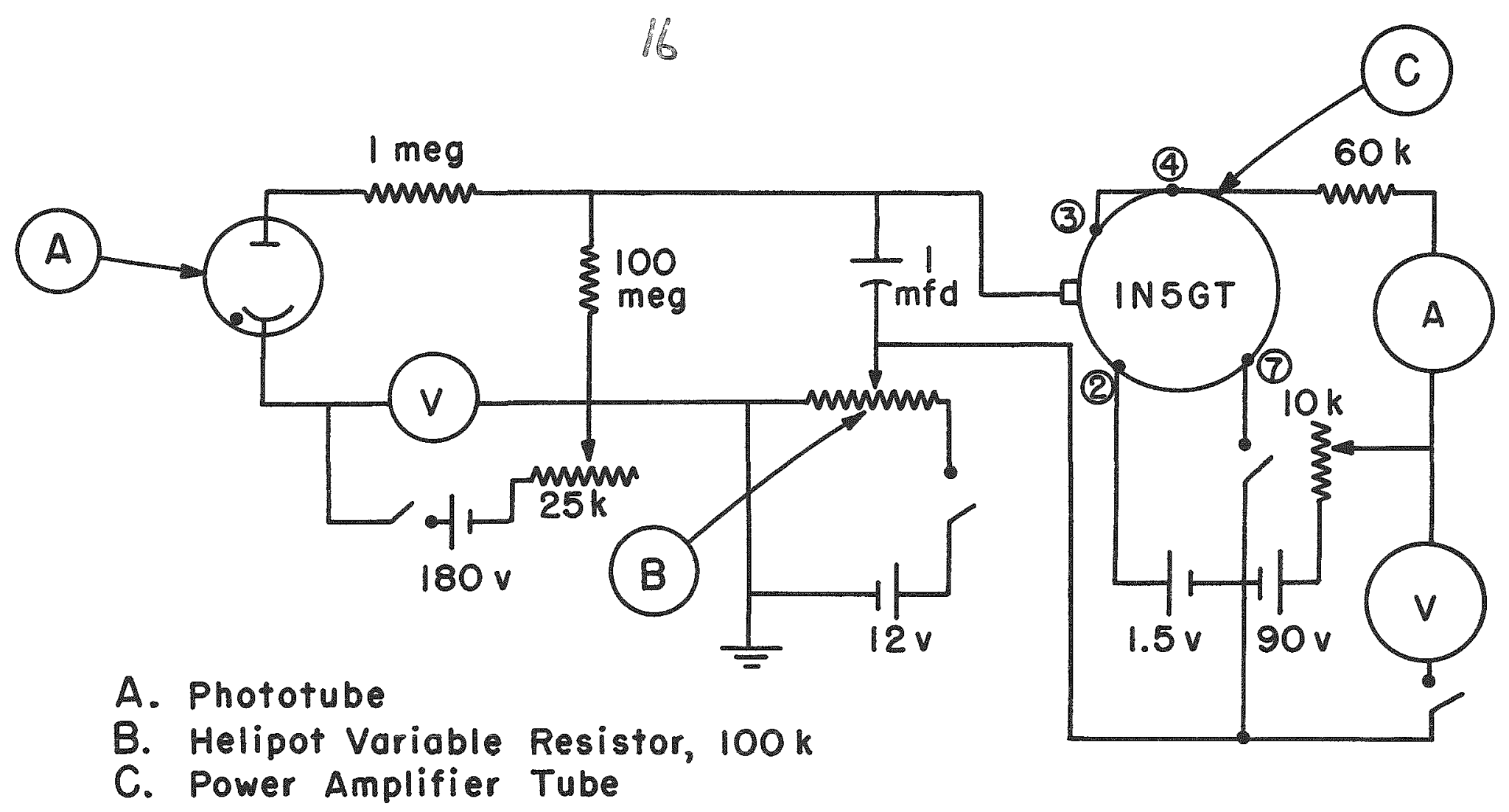

Fig. 7. Circuit Diagram of Equipment Used to Measure Photocell Response 


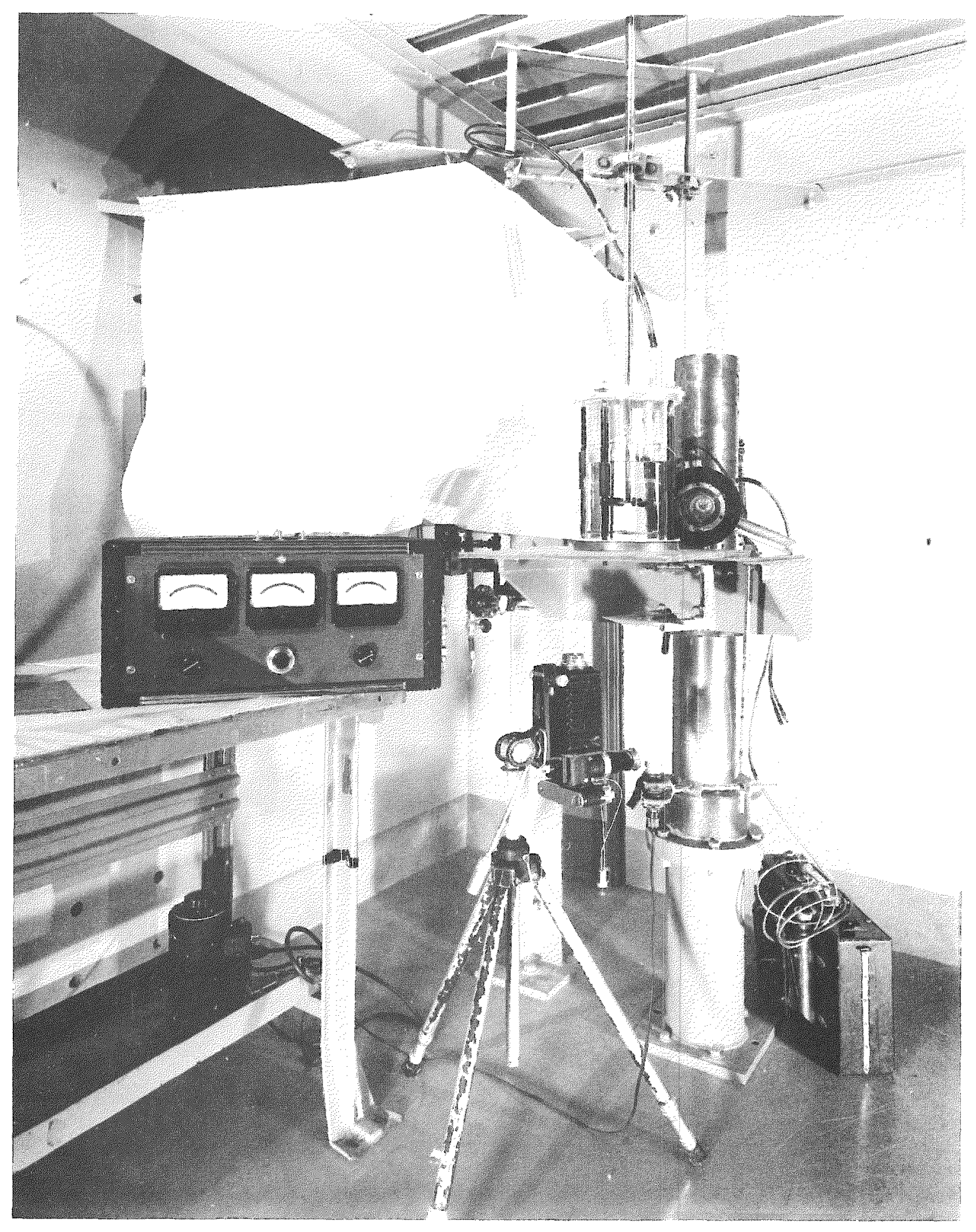

Fig. 8. Photograph of Experimental Equipment 


\section{CHAPTER III \\ MEASUREMENT OF INTERFACIAL AREA}

The interfacial area measurements herein reported were obtained in two ways: photographically and by the use of a correlation developed between interfacial area and light transmission. The results of this portion of the work have been published separately $(35,36)$ in detailed form. A summary of this work is given here.

Previous Work

Most of the interest in light scattering has been restricted to very dilute monodisperse* systems of small particles generally less than one micron in diameter. Mathematical treatments of concentrated polydisperse** systems are not available. In addition, there are few quantitative data available relative to liquid-liquid or gas-liquid dispersions.

In 1925 Stamm and Svedberg $(30)$ were interested in the relationship between the right-angle scattering of light and the size distribution of soap-stabilized benzene-water emulsions. They suggested a linear relationship between light transmittance and concentration for a given particle size. Clark and Blackman (5) investigated light transmittance as a measure of the interfacial area foams. On the basis of admittedly qualitative data, a linear relationship between light transmittance and volumetric area was suggested.

*Monodisperse in the sense that all particles in the dispersion are the same size.

** Polydisperse in the sense that a distribution of particle size is present. 
Recently, Langlois and co-workers $(19,20)$ published a correlation of light transmission with interfacial area for liquid-liquid systems. Their results were correlated empirically by a linear equation in the following form:

$$
\frac{I_{0}}{I}=1+\beta a
$$

where

$$
\begin{aligned}
& \frac{I_{0}}{I}=\text { the ratio of incident to emergent light intensity } \\
& a=\begin{array}{l}
\text { interfacial area per unit volume total mixed phases } \\
\text { (volumetric area) }
\end{array} \\
& \beta=\text { a constant characterizing a specific liquid pair. }
\end{aligned}
$$

This relationship was considered to be independent of the volume fraction dispersed phase. The constant, $\beta$, was given as a function of the relative refractive index of the dispersed phase.

The papers by Langlois et al, are of particular interest because they represent the first successful attempt to establish a quantitative relationship between light transmission and volumetric area. However, the reproducibility of results obtained with a given probe was poor and each probe required individual calibration. (18) Duplication of this work would be difficult.

It is apparent from the literature that the quantitative equations relating particle size and concentration to light transmittance are limited and cannot be applied to polydisperse systems of large spherical particles. The available empirical relationships for polydisperse 
systems do not demonstrate satisfactory accuracy and precision. In addition, it is difficult to reproduce the equipment design and each detector unit requires individual calibration.

Theory

The light transmitted through a polydisperse system of transparent isotropic spherical particles provides a measure of the interfacial area if it can be demonstrated that light transmission is a function of the total projected area. This means that it must be shown that the light transmission is a function of the mean surface-volume diameter or Sauter, $d s v$. Conversely, a correlation is not possible if the scattered light energy is sensitive to the particle size distribution. For a polym disperse system consisting of $\mathrm{N}_{i}$ particles of diameter $d_{i}$ in a given size interval:

$$
\mathrm{d}_{\mathrm{sV}}=\frac{\sum \mathrm{N}_{\mathrm{i}} \mathrm{d}_{\mathrm{i}}^{3}}{\sum \mathrm{N}_{\mathrm{i}} \mathrm{d}_{\mathrm{i}}^{2}}
$$

For a volume fraction of dispersed phase of $f$, the volumetric area is defined as follows:

$$
a=\frac{6 t}{d_{s V}}
$$

The factors which control light transmittance are embodied in the familiar extinction or Beer-Lambert relationship:

$$
\operatorname{SndL}=\frac{\mathrm{dI}}{\mathrm{I}}
$$

The scattering cross section, $S$, is the ratio of the light energy lost by scattering to the incident light energy per unit area and $n$ is the number 
of particles per unit volume. Integrating over the distance between light source and detector, $L$, as the incident light diminishes from $I_{0}$ to $I_{\text {, the }}$ conventional extinction equation is obtained:

$$
\ln \frac{I_{0}}{I}=S n L=K_{S} \frac{d^{2} \pi}{4} n L
$$

where

$$
K_{\mathrm{s}}=\frac{4 S}{d^{2} \pi}
$$

$d=$ particle diameter.

Calculations by several investigators $(3,9,11,16,29)$ indicate that the scattering area coefficient, $\mathrm{K}_{\mathrm{S}}$, is extremely sensitive to particle size near the wavelength of the incident light. However, the effect of particle diameter decreases with increasing particle size and $\mathrm{K}_{\mathbf{S}}$ is found to be relatively constant for particles larger than 50 microns. Other investigators, Bailey $(1)$ and Rose and French $(24)$ have verified this observation by purely experimental methods.

In this investigation the observed particle size distribution has generally been between 50 and 1000 microns and the scattering area coefficient may be considered as a constant with respect to particle diameter. Therefore, the drop diameter, $d$, may be defined as the mean surface-volume diameter, $d_{S v}$, and equation (5) may be written in terms of the interfacial area per unit volume of total mixed phases, a, and a scattering factor, $\alpha$ 。

$$
\ln \frac{I_{0}}{I}=\frac{K_{s}}{4} L a=\alpha L a
$$


For a given incident light wavelength the scattering factor, $\alpha$, should be a unique function of the relative refractive index of the liquid pair. In the basic relationship, equation (4), it is assumed that light once scattered from the path of the primary beam is lost. This is true only for very dilute dispersions. However, for the systems studied, light scattered from the primary beam may be returned to the original path by secondary scattering. Hence, multiple scattering is an important factor which must be considered. The effect of multiple scattering is a function of both the relative refractive index and the incident light beam diameter.

Other factors which may be considered to have a significant effect on the transmittance relationship are functions of the light source and detector geometry. For example, consider the problem of measuring the emergent light intensity, I. The incident light, I0, is a collimated beam. The emergent light, $I$, is defined as that portion of $I_{0}$ which passes unimpaired through $\mathrm{L} \mathrm{cm}$ of dispersion. This means that the emergent light is that portion of the incident light scattered in the forward direction parallel to the path of the primary beam. Gumprecht and Sliepcevich $(10)$ point out that it is technically impossible to obtain an exact measure of the emergent light. Any detector design will measure, in addition to light scattered in the forward direction, some of the light scattered at small angles from the path of the primary beam.

The basic transmission relationship (equation 7) may be modified to conform with these practical considerations: 


$$
\ln \frac{I_{0}}{I}=f\left(\alpha, a, L_{0}\right)
$$

Equation (8) shows that an exponential relationship exists between the light transmittance and some function of $\alpha, a$, and $L$. The exact nature of the function must be determined experimentally.

\section{Experimental}

Experimental techniques and equipment were developed to meas ure the interfacial area per unit volume of total mixed phases (volumetric area), and the light transmittance of the dispersion at a specified optical path. The volumetric area was determined photographically, and the light transmittance by photoelectric measurements.

Dispersions were created in the 5-9/16 inch diameter mixing vessel already described (see Figure 3).

The volumetric area which exists in a liquid-liquid system during mixing was determined from photographs of the dispersion. Photographs were taken through the base of the mixing vessel with a 35 -mm Leica camera fitted with an Ektar 5 -cm lens, reflex prism, and close range bellows using Kodak Plus-X film. Illumination was provided by a $0.0002-$ second Comet 100-watt-second strobe light mounted beside the vesse1. Light from the droplets reached the camera by reflection. Pictures with good drop resolution were obtained by over-exposing the film by one stop and double-developing the negative. Resolution was improved by photographing through a G filter. A typical photograph is shown in Figure 9. 


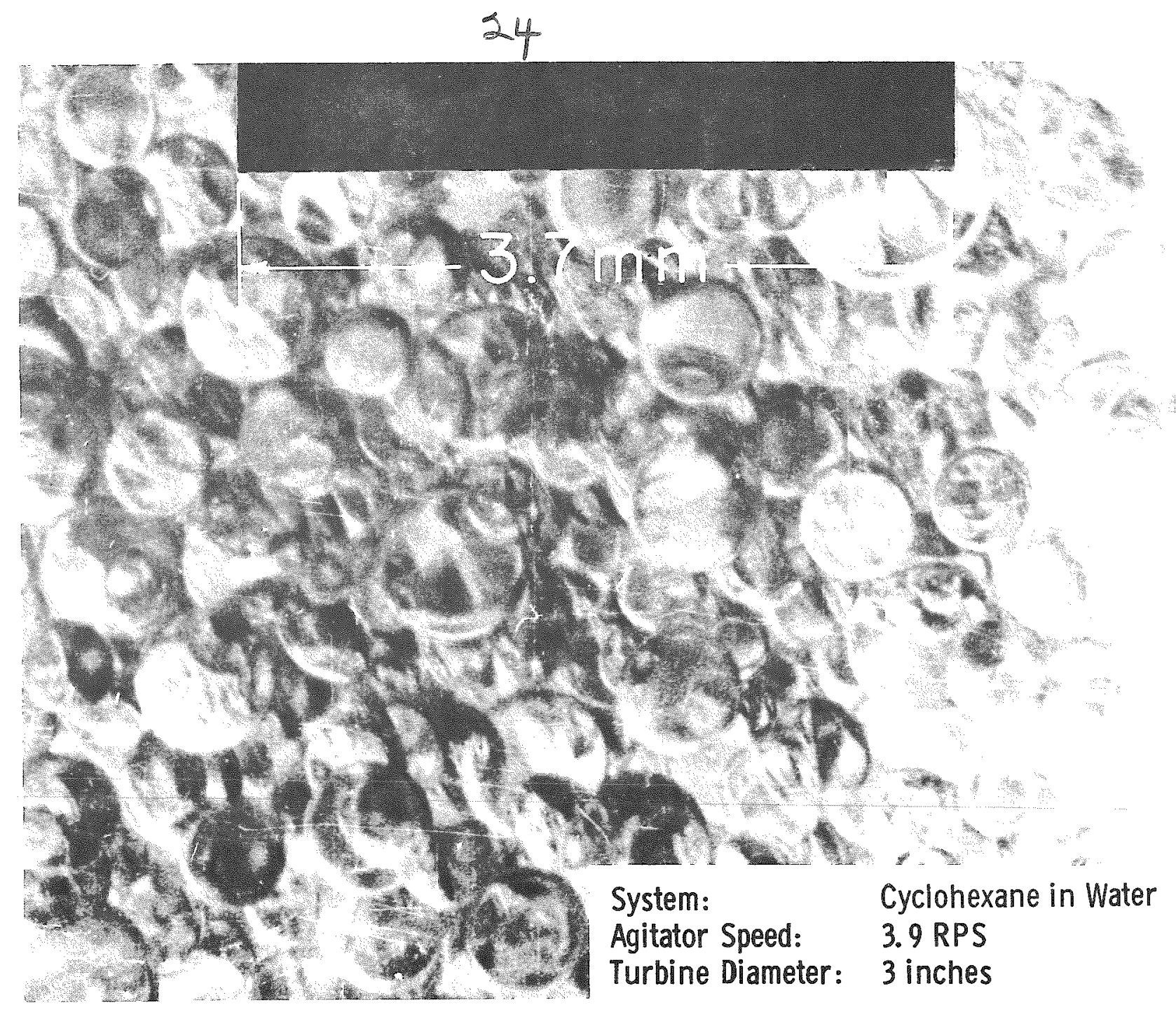

Fig. 9. Typical Photograph of Dispersion 
Preliminary runs were made to establish techniques for area measurements in a rectangular cross section mixing vessel specially designed to facilitate photographic study. An assortment of glass beads dispersed in a mixture of carbon tetrachloride and tetrabromoethane was photographed. These beads ranged in diameter from 210 to 710 microns. Several observers working independently determined the interfacial area from photographs by tracing the droplets in the plane of focus and by classifying the diameters.

The precision of the technique is shown by the data of Table 1. The accuracy of the technique is apparent from a size frequency plot, Figure 10, which compares the experimentally determined size distribution with the distribution determined by classification of the beads into sieve sizes. Both the accuracy and precision of the photographic method, based on measurements by several independent observers, are shown to be better than plus or minus five per cent.

In determining the correlation, equal volume portions $(1080 \mathrm{ml})$ of each phase were placed in the mixing vessel and equilibrated from two to four hours to saturate the liquid pair mutually. Commerical or reagent grade organic liquids, pretreated by distillation, were used. The aqueous phase was distilled water or glycerin-water mixtures. Runs were made at $25 \pm 1 \mathrm{C}$ and refractive indices were determined at $25.0 \mathrm{C}$.

For each system a series of transmittance measurements was obtained. Simultaneously, photographs of the dispersion were taken to 
Table 1. Glass Bead Test for Accuracy and Precision of Photographic Method for Measuring Interfacial Area

A. Photographically Determined Interfacial Area

Observer

A

B

C

D

$\mathbf{E}$ $\mathrm{sq} \mathrm{cm}$

$\overline{\mathrm{cucm}}$

123

121

125

122

122

B. Interfacial Area Determined by Classification

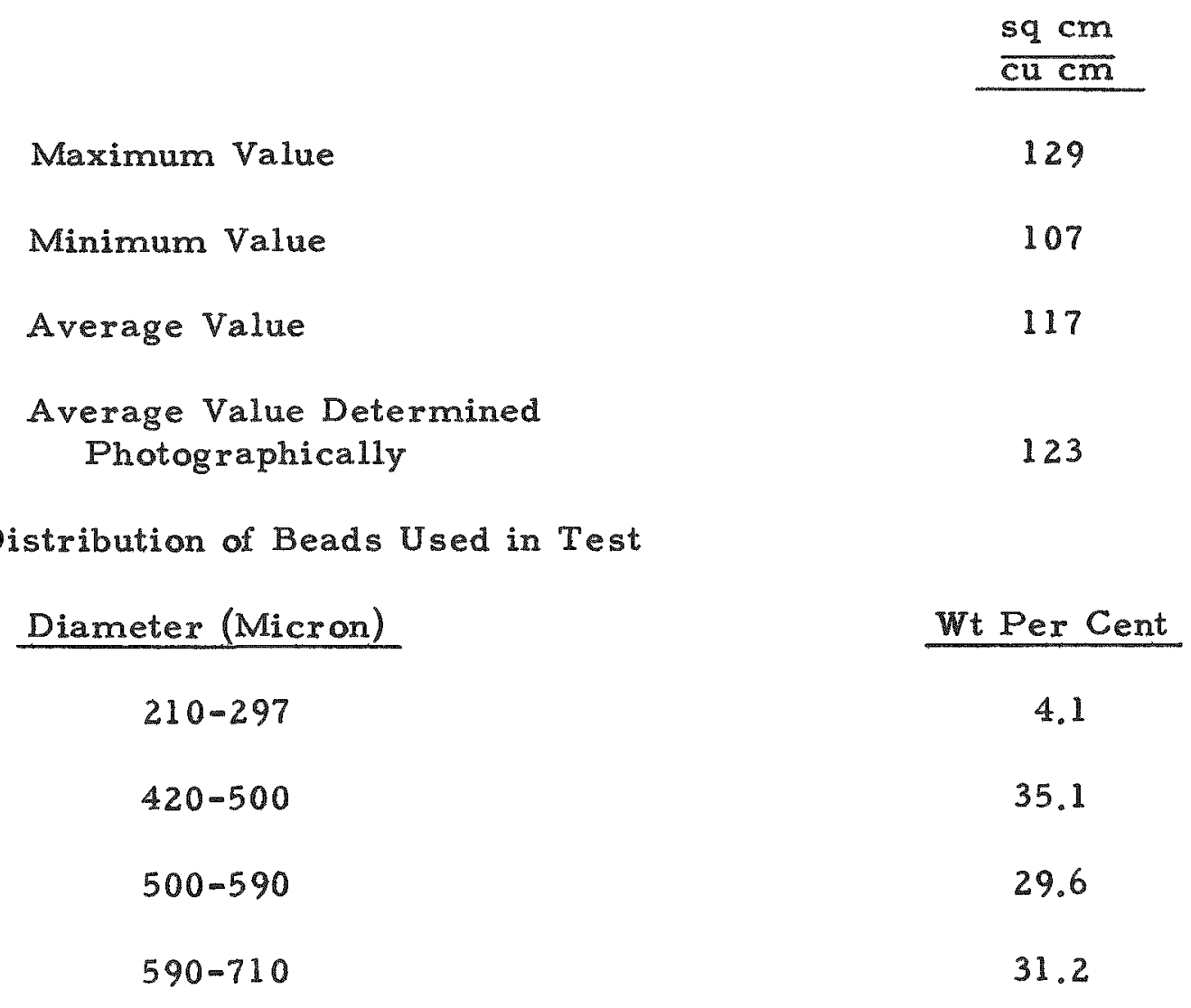




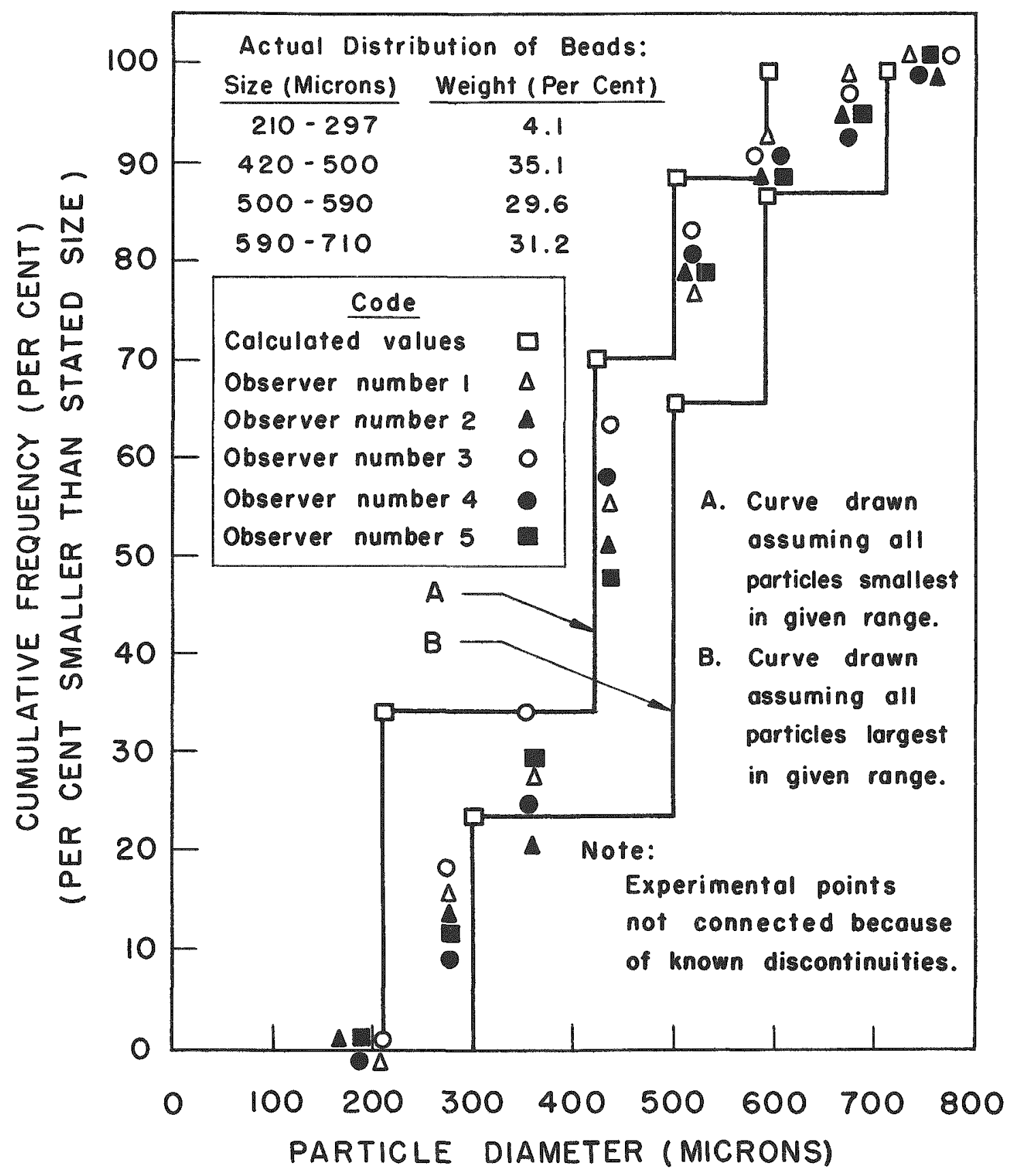

Fig. 10. Comparison of Calculated Size Frequency of Dispersed Glass Beads with Measured Values Obtained by Several Observers 
provide a measure of the volumetric area. The specific volumetric area under a given set of conditions was found to be reproducible if surface active contamination were absent. To minimize contamination, the equipment was thoroughly cleaned with acetone, water, aciddichromate cleaning solution, water, and distilled water in that order. The incident light, $I_{0}$, was defined as the light energy per unit area measured through the clear field phase before emulsification, while the emergent light, $I_{2}$ was defined as that portion of the incident light which reached the detector probe after emulsification.

The reading of the incident light was arbitrarily controlled by the voltage applied to the light source. Mixing was begun and emergent light readings taken when steady state conditions were reached (from 2 to $45 \mathrm{~min}$ ) as indicated by a constant transmittance reading. Immedi= ately after each emergent light reading, a measurement was taken to establish the reading for zero transmittance, as small changes in this quantity have considerable effect on the value obtained for the emergent light.

Correlation of Transmittance Data

The experimental data were correlated empirically as shown in Figures 11 and 12 corresponding to the two light sources and detectors described in Chapter II. Figure 12 represents the more refined equipment (Correlation B) and was used for most of the data reported herein. The scattering factor, $\alpha$, is a complex function of the scattering cross section, S. Where the particle diameter is small with respect to 


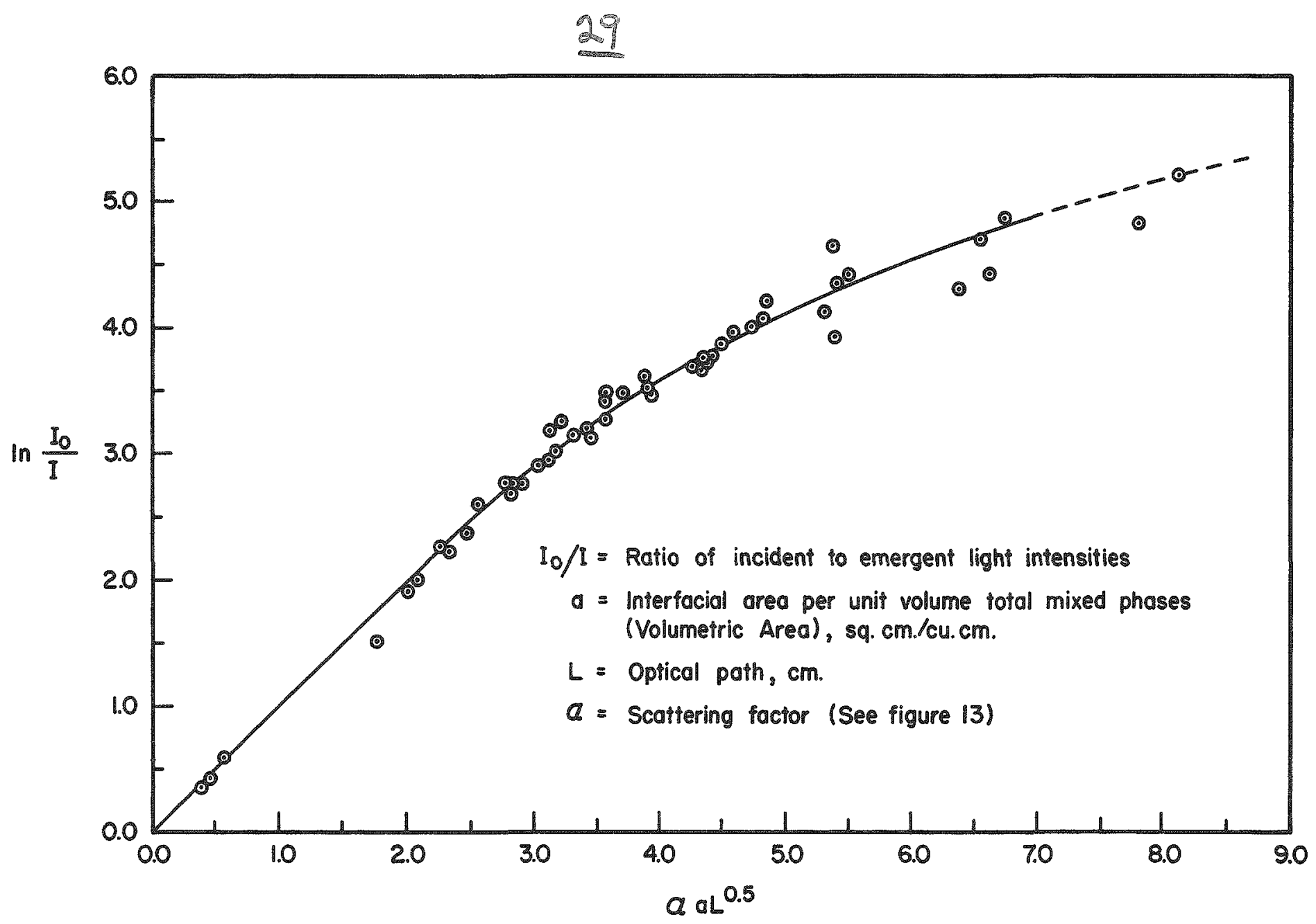

Fig. 11. Correlation (D) of Light Transmittance with Volumetric Area 


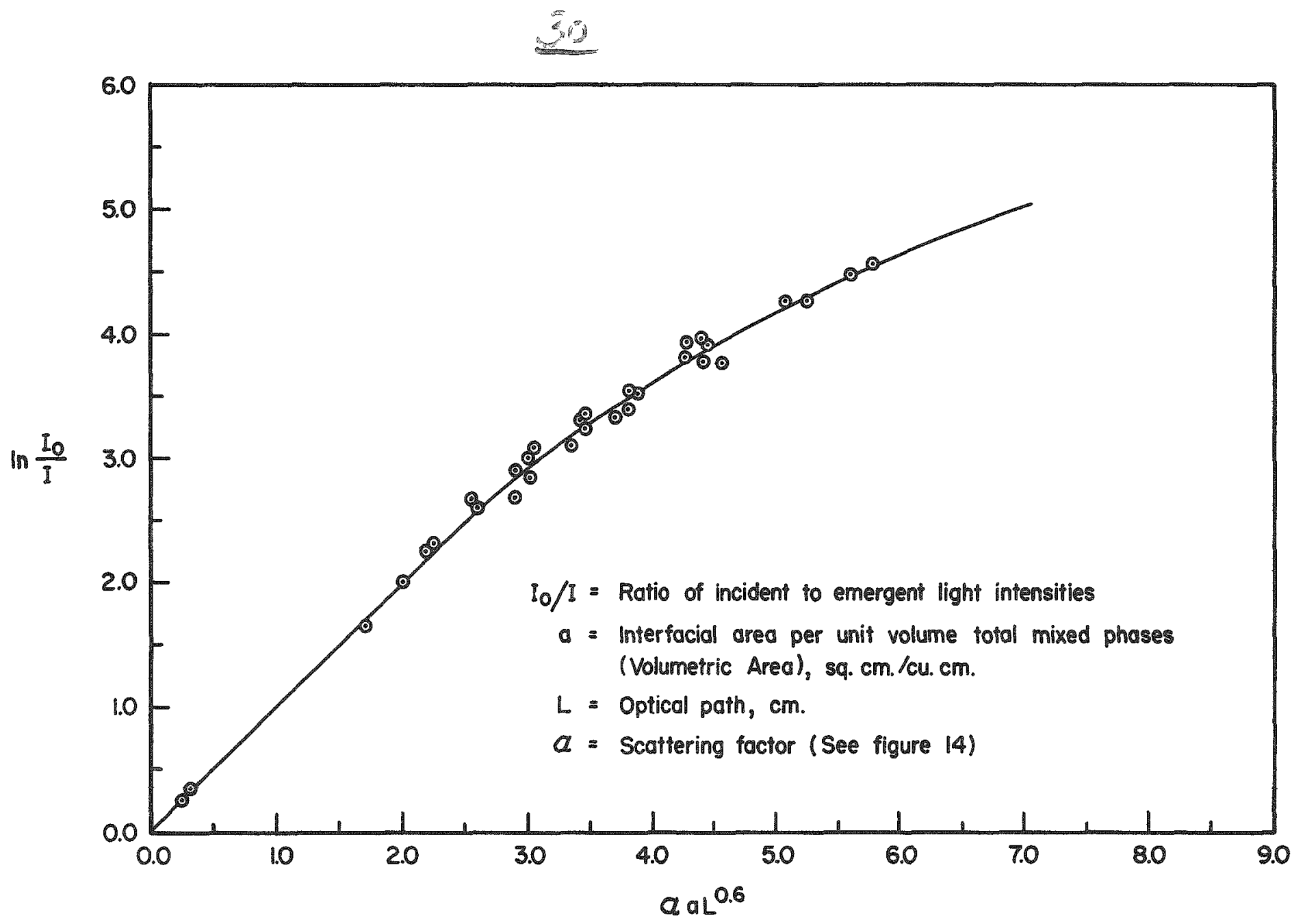

Fig. 12. Correlation (B) of Light Transmittance with Volumetric Area 
the wavelength of the incident light, the scattering cross section is a simple function of the specific refraction, $M,(23)$ sometimes referred to as the Lorentz coefficient:

$$
M=\left|\frac{m^{2}-1}{m^{2}+2}\right|
$$

where

$\mathrm{m}=$ refractive index of drop/refractive index of field phase. For large spherical particles the scattering cross section is a complex function of the Lorentz coefficient. Bailey(1) and Rose and French ${ }^{(24)}$ used the Lorentz coefficient as the refractive index parameter in their work with particle sizes up to about ten microns. In the present work the Lorentz coefficient proved to be a satisfactory correlating optical parameter for polydisperse systems consisting of particles from 50 to 1500 microns in diameter as evidenced by Figures 13 and 14. The Lorentz coefficient should be evaluated at the wavelength of the incident light. However, a satisfactory correlation was obtained with the refractive index measured at the more convenient sodium $D$ line. The generalized correlations (Figures 11 and 12), which show light transmittance as a function of interfacial area, optical path, and an optical parameter, are valid only for the conditions of this investigation. These conditions are: the light source and detector geometry as shown in Figures 4 and 5 , the incident light spectrum as shown in Figure 6 , transparent liquids, and a volume fraction of the dispersed phase of 0.50 . 


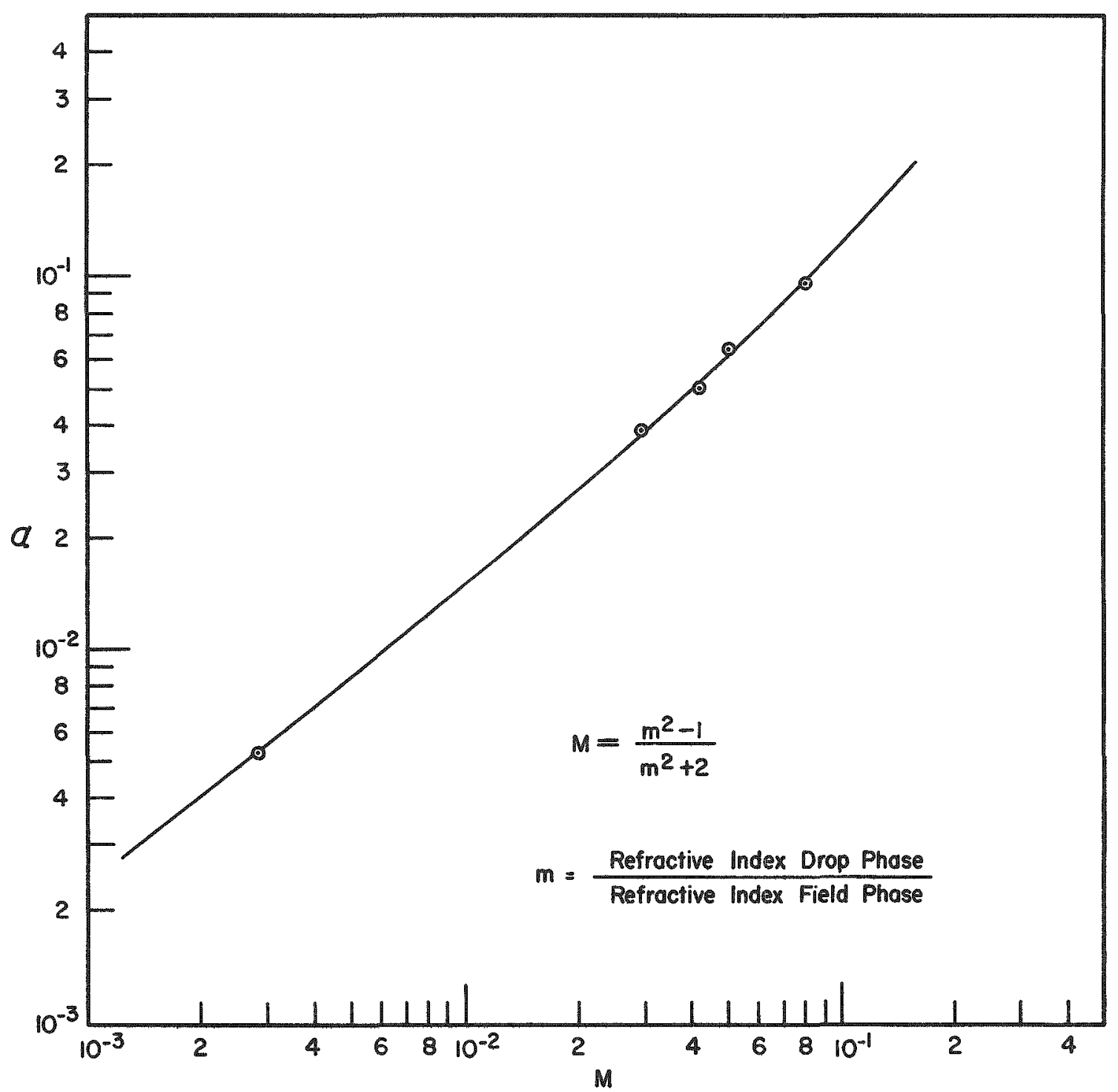

Fig. 13. Scattering Factor, $\alpha$, as a Function of the Relative Specific Refraction, M. Correlation D. 


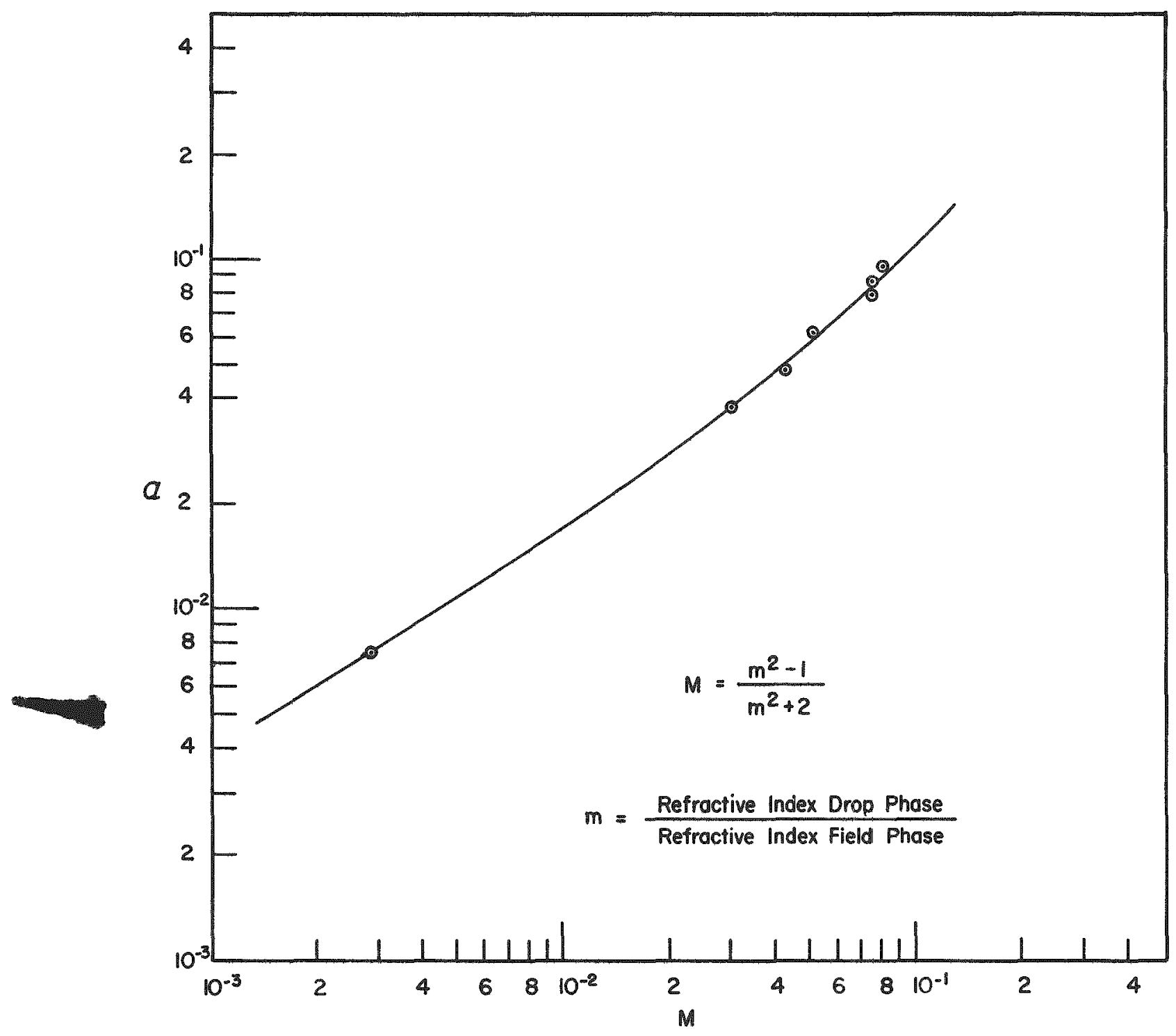

Fig. 14. Scattering Factor, $\alpha$, as a Function of the Relative Specific Refraction, M. Correlation B. 
Reproducibility of Data

Consecutive transmittance readings were reproducible to within three per cent and in most cases one per cent. In the case of duplicate runs, with the same supply of the liquid pair, the introduction of additional variables such as substitution of probes and readjustment of the optical path length caused some loss in reproducibility. However, transmittance measurements for these duplicate runs were usually within three per cent and rarely varied by as much as five per cent. Both area and transmittance data used in the correlation were obtained from measurements at the bottom of the mixing vessel. For that reason, there can be little doubt that the photographically deter = mined areas represented the area at the point where the transmittance measurements were obtained. However, even considering the extreme degree of turbulence in these agitated systems, there might be some question concerning the homogeneity of the bulk of the dispersion, particularly near the agitator. To resolve this question a simple test was devised which showed the dispersions to be essentially homogeneous. A portable one-piece detector-source unit consisting of phototube and flash light bulb was placed in several different locations in the mixing vessel. Within the limits of experimental precision, no variation in light transmittance was observed indicating essentially complete homogeneity of the dispersion. 
In each series of runs the following procedure was followed:

1) The liquids to be used were carefully purified and all equipment which would come in contact with the liquids was cleaned.

2) The vessel was filled with a 50 per cent (by volume) mixture of the system under study to a height equal to the diameter of the vessel. The liquids were then equilibrated for several hours and the temperature brought to $25 \mathrm{C}$.

3) With each of the impellers, data were taken at several impeller speeds. These consisted of a reading of light transmission and the taking of one or more photographs for the determination of interfacial area. Following this the time necessary for the dispersion to settle to the appearance of the first clear interface was measured.

4) At the conclusion of the run samples were taken of each phase and the density, viscosity and refractive index of each and the interfacial tension between the two were measured.

Control of Contamination

It became evident very early in this investigation that small amounts of contamination were capable of significantly affecting the properties under study-- particularly the settling time of the dispersions. Consequently, except in those cases where contamination was deliberately courted or introduced, efforts were made to keep the liquids and the equipment scrupulously clean. 
The equipment was located in a small isolated room and unnecessary traffic was discouraged. The entire room, walls and ceiling included, was regularly vacuumed to reduce dust loading in the air. The air supply to the room was filtered and air conditioned. Smoking was prohibited.

One of the liquids used was always water. Since there appeared to be little or no difference between the behavior of the regularly supplied building distilled water and double distilled water, the former was used throughout. The organic liquid was distilled prior to use. The distillation scheme used depended upon the particular liquid. Vacuum, atmospheric, and steam distillations were employed. The glass mixing vessel was first cleaned with cleaning solution, thor oughly rinsed with distilled water then with acetone and finally with more distilled water. The impellers and baffles were dipped into nitric acid, rinsed with water, acetone and then water. The cleaned equipment was handled as little as possible and only with clean hands. The equipment was kept covered as much as possible. From time to time the temperature of the dispersion was taken with a glass thermometer. This was cleaned with acetone each time before use. Equilibration

The purified liquids were measured into the cleaned mixing vessel such that the volume fraction was 50 per cent and the total height of the liquid equalled the inside diameter of the tank. One of the intermediate sized impellers to be used was then inserted into the 
vessel and the mixture stirred just rapidly enough to produce a complete dispersion. The equilibration was continued for several hours to insure the mutual saturation of the phases. During this time the temperature was brought to $25 \mathrm{C}$. This was generally not difficult since except on the hottest days in summer, the room temperature was just about $25 \mathrm{C}$. The temperature of the vessel and contents was raised by shining a heat lamp on it and lowered by inserting a cleaned stainless steel cooling coil.

Al1 runs were made at $25 \pm 0.5 \mathrm{C}$. Generally the temperature was within $0.1 \mathrm{C}$ of the reference temperature.

Method of Obtaining Data

After equilibration was adjudged complete, runs were made to obtain interfacial area and settling time for each of several impellers at several impeller speeds.

In the 6-inch tank, the impeller speed was determined by using the no-load calibration speed of the stirrer which had been determined for each position on the selector switch by the use of a revolution counter and stop watch. In the 12-and 18-inch tanks with impeller diameters of 6 inches or more, sufficient power was drawn that the Thy-Mo-Trol unit did not maintain an adequately constant speed between no- and full-load. Therefore in these cases higher speeds were determined by the use of a Strobotac and low ones by tactilely counting the rpm. 
For each impeller it was necessary to use a speed sufficiently great to produce a complete emulsion. This could be determined visually but was even more evident from observation of the sensing galvanometer in the light transmission circuit. Steady probe readings could not be obtained below the speed of complete dispersion. The highest impeller speed used was that which just began to beat air into the system. It was usually possible to obtain four or five points for each impeller. In the 6-inch tank, the 2-, 3-, and 4-inch impellers were used. In the 12 -inch tank data were obtained using the $2-, 3-, 4-, 6-$, and 8-inch turbines; while in the 18-inch tank it was possible to use the $3-, 4-, 6-, 8-, 9-$, and 12-inch impellers.

The most important determination made was that of interfacial area. This was done in two ways: photographically and by means of a light transmission correlation. The photographic method is tedious and was used only as an occasional check once the light transmission method was worked out (see Chapter III).

After the light readings and photographs were taken, the impeller was stopped and the time for the dispersion to settle to the first appearance of clear interface was noted with a stop watch. For any given supply of liquid this value was reasonably reproducible. It was in this quantity, however, that the effect of contamination was most apparent. It was observed that for a given system, settling times differing by several hundred per cent were quite possible. The longer settling times were characterized by the appearance at the interface 
of a pearly gray film. Seldom could any significant difference be found in any of the physical properties - even interfacial tension - when this phenomenon was observed.

During the settling a visual observation was made of the type of dispersion which had been created. A settling system has the appear = ance of a threemphase system consisting of a relatively clear volume both above and below the band of uncoalesced emulsion. At one of the interfaces the rate of travel toward the eventual interface takes place due to the settling alone. This is a relatively quiescent interface. At the other the droplets grow rapidy in size by combining with one another and with the bulk clear phase with which they are in contact. This coalescing interface is a very active one. The clear phase above (or below) the coalescing interface is the continuous phase. This is illustrated schematically in Figure 15. Measurement of Physical Properties

At the conclusion of each series of runs, samples were taken of each of the settled phases. The following physical properties were obtained:
1) density
2) viscosity
3) refractive index
4) interfacial tension. 


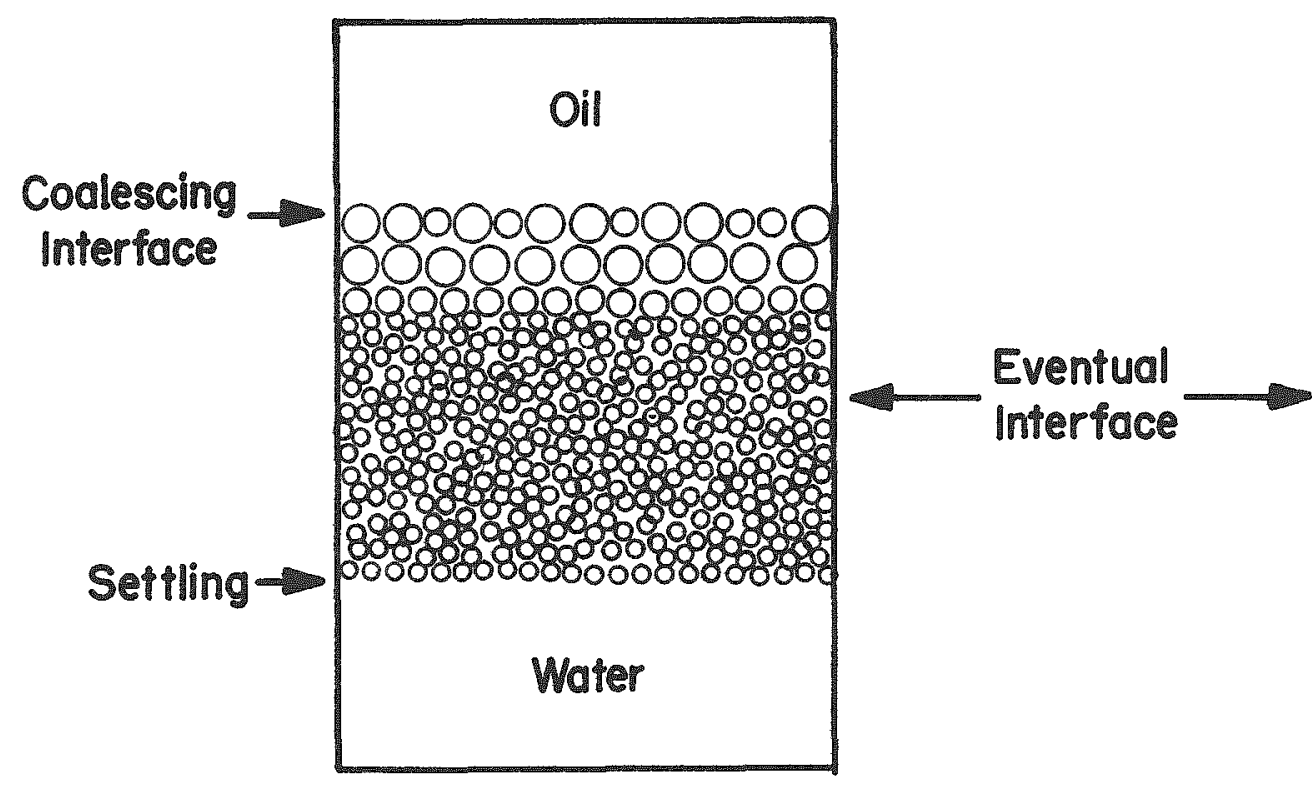

O/W Dispersion

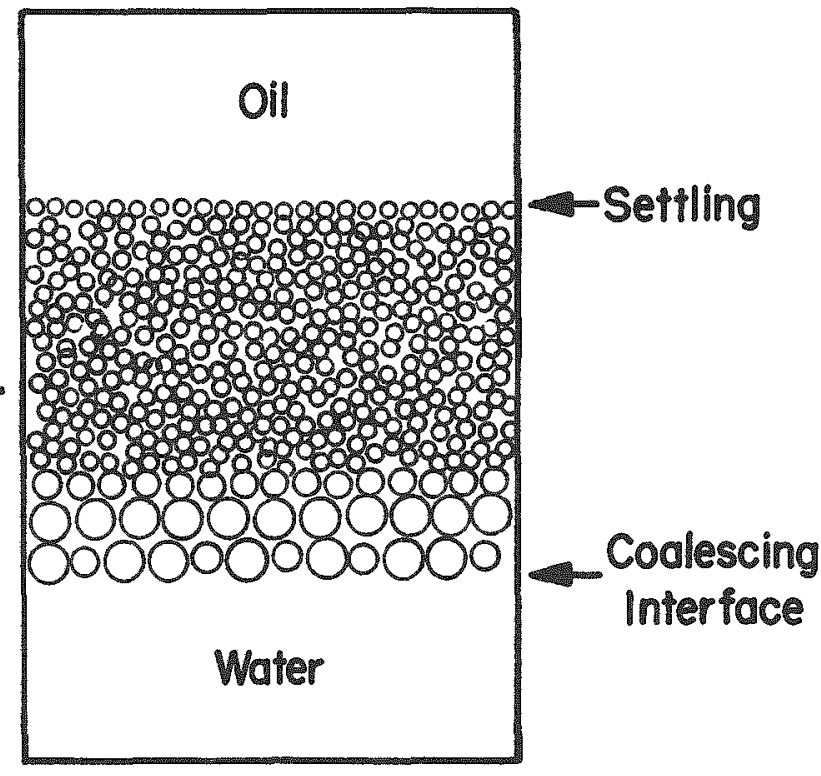

W/O Dispersion

Fig. 15. Illustration of Types of Coalescence. 
Density was obtained using pycnometers thermostated to $25 \mathrm{C}$. Viscosity was obtained at the same temperature using Ostwald viscosimeters and the refractive index was obtained using a standard refractometer.

Interfacial tension was obtained by use of the Harkins drop= weight method $(12)$ in the equipment illustrated in Figure 16. 


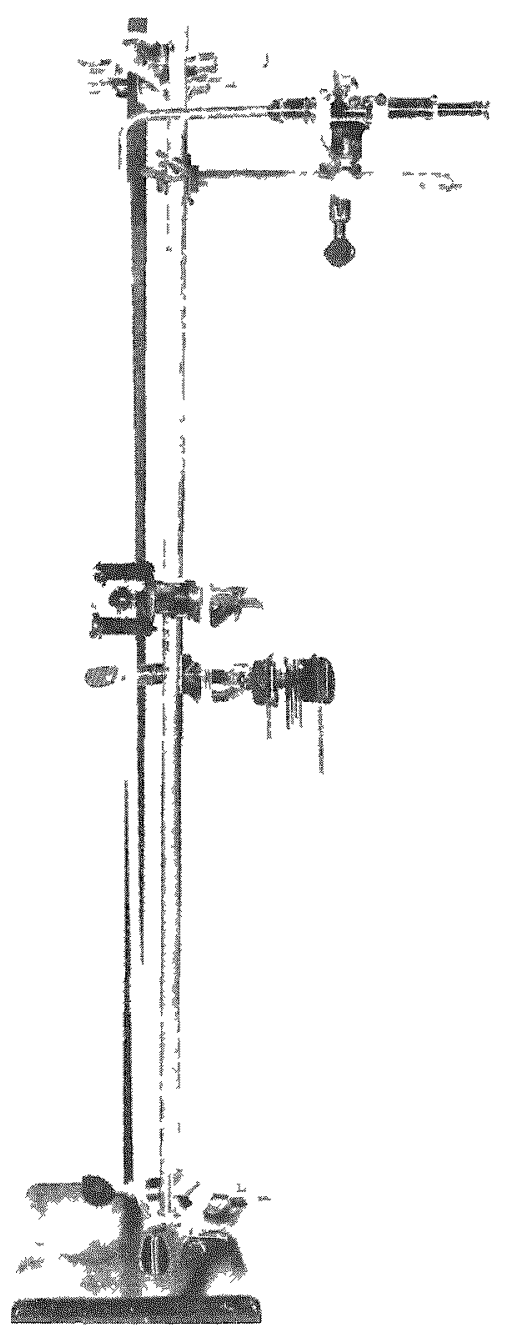

A. For Use with Organic Phase Lighter than Water

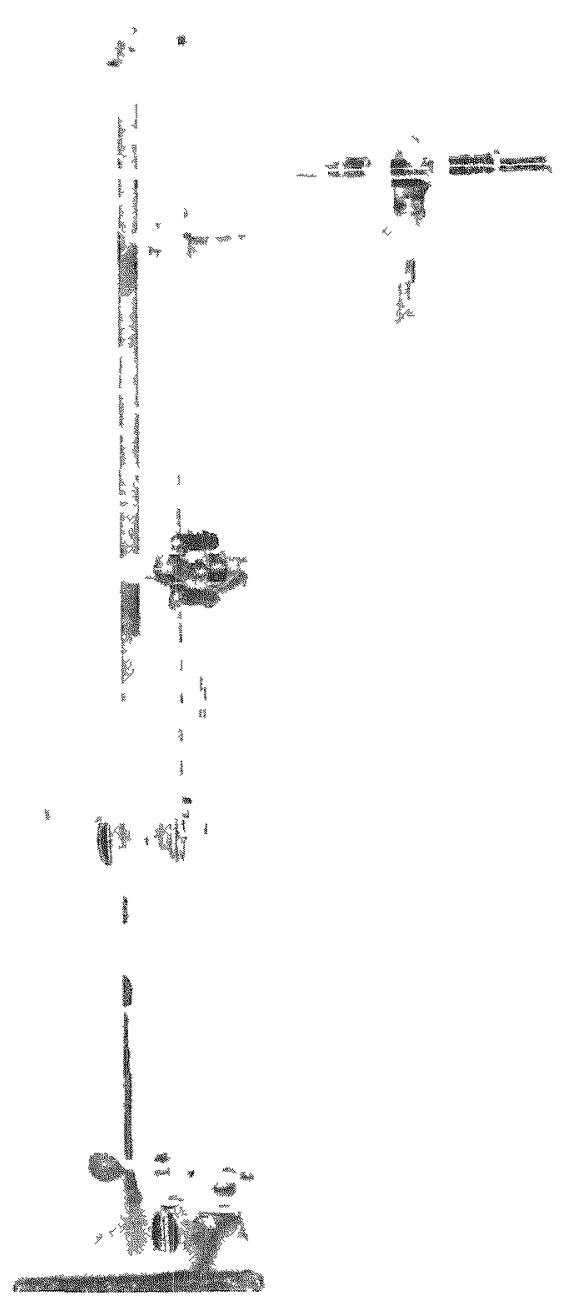

B. For Use with Organic Phase Heavier than Water

Fig. 16. Tensiometers for Measurement of Interfacial Tension 


\section{CHAPTER V \\ EXPERIMENTAL RESULTS}

Systems Studied and Results

Data were obtained on a total of 17 systems. These systems are listed in Table 2 together with the density, viscosity and refractive index of the mutually saturated (at $25 \mathrm{C}$ ) liquids and the interfacial tension between them. The systems were selected to give as wide a range of physical properties as possible within the limitations of the area-light transmittance correlation.

All 17 systems were run in the 6 -inch vessel using $2-3-3-$, and 4 -inch impellers at a variety of speeds. The interfacial areas and settling times observed are given in detail in the Appendix (Table 4). The supporting light transmittance data are shown in Table 7 also in the Appendix.

Four of the systems [Amsco (kerosene), Hexone (methyl isobutyl ketone), xylene, and isobutanol] were also run in the 12-and 18-inch tanks. These data are shown in Tables 5,6,8, and 9 in the Appendix. The treatment of these data is discussed in the following subsection.

Correlation of Data

It was originally felt that the following variables would be of importance in this investigation: 
Table 2. Physical Properties of Systems Studied

\begin{tabular}{|c|c|c|c|c|c|c|c|c|}
\hline \multirow[b]{2}{*}{ Run } & \multirow[b]{2}{*}{ Systemb } & \multicolumn{2}{|c|}{$\begin{array}{l}\text { Density } \\
\text { Field Drop }\end{array}$} & \multicolumn{2}{|c|}{ Viscosity } & \multirow{2}{*}{$\begin{array}{c}\text { Inter } \\
\text { facial } \\
\text { Tension } \\
\sigma_{i} \\
\text { dynes/cm }\end{array}$} & \multicolumn{2}{|c|}{$\begin{array}{l}\text { Refractive } \\
\text { Index }\end{array}$} \\
\hline & & $\rho_{\mathrm{F}}$ & $\mathrm{em}_{\mathrm{D}}^{\rho_{\mathrm{D}}}$ & $\mu_{\mathrm{F}}$ & $\mu_{\mathbb{D}}$ & & $\eta_{\text {Field }}$ & $\stackrel{\text { Drop }}{\eta_{D}}$ \\
\hline 922 & Cyclohemane & 0.997 & 0.761 & 0.894 & 0.762 & 49 & 1.3329 & 1.4181 \\
\hline 31 & Amsco ${ }^{\circ}$ & 0.994 & 0.774 & 0.884 & 1.081 & 44.1 & 1.3330 & 1.4330 \\
\hline 628 & Amscod & 0.997 & 0.771 & 0.889 & 1.020 & 44.1 & 1. 3332 & 1.4326 \\
\hline $\begin{array}{r}1028 \\
113\end{array}$ & Amscod & 0.997 & 0.774 & 0.883 & 1.086 & 44.2 & 1.3330 & 1.4348 \\
\hline $\begin{array}{r}119 \\
1111\end{array}$ & Xylene & 0.997 & 0.860 & 0.903 & 0.615 & 38.1 & 1.3329 & 1.4940 \\
\hline 23 & Xylene & 0.997 & 0.860 & 0.989 & 0.605 & 37.2 & 1.3330 & 1.4944 \\
\hline 29 & $\begin{array}{c}5 \% \text { White Oil } \\
\text { in Xylene }\end{array}$ & 0.997 & 0.860 & 0.890 & 0.677 & 37.6 & 1.3331 & 1.4919 \\
\hline 214 & $\begin{array}{l}28 \% \text { white oil } \\
\text { in Xylene }\end{array}$ & 0.997 & 0.864 & 0.892 & 1.202 & 38.0 & 1.3330 & 1.4889 \\
\hline 224 & $\begin{array}{c}61 \% \text { White oil } \\
\text { in Xylene }\end{array}$ & 0.997 & 0.871 & 0.889 & 7.416 & 45.1 & 1.3330 & 1.4829 \\
\hline 314 & Benzene & 0.997 & 0.873 & 0.896 & 0.607 & 40.2 & 1.3332 & 1.4975 \\
\hline 216 & Hexone & 0.995 & 0.800 & 0.925 & 0.578 & 10.8 & 1.3346 & 1.3940 \\
\hline $\begin{array}{l}1121 \\
1123\end{array}$ & Hexone & 0.995 & 0.800 & 0.931 & 0.591 & 10.6 & 1.3347 & 1.3943 \\
\hline 75 & $\begin{array}{c}20 \% \mathrm{CCl}_{\text {in }} \\
\text { Benzene }\end{array}$ & 0.9970 & 1.0144 & 0.894 & 0.661 & 35.8 & 1.3332 & 1.4901 \\
\hline 727 & $\begin{array}{c}11 \% \mathrm{CCl}_{4} \text { in } \\
\text { Benzene }\end{array}$ & 0.9968 & 0.9574 & 0.918 & 0.656 & 30.6 & 1.3330 & 1.4985 \\
\hline 728 & $\begin{array}{c}25 \% \mathrm{CCl}_{\text {in }} \text { in } \\
\text { Benzene }\end{array}$ & 0.997 & 1.038 & 0.890 & 0.680 & 35.0 & 1.3330 & 1.4896 \\
\hline 28 & $\begin{array}{c}28 \% \mathrm{CCl}_{4} \text { in } \\
\text { Benzene }\end{array}$ & 0.9970 & 1.0749 & 0.893 & 0.689 & 34.7 & 1.3339 & 1.4867 \\
\hline 927 & Chlorobenzene & 0.997 & 1.101 & 0.890 & 0.766 & 37.7 & 1.3329 & 1.5218 \\
\hline 730 & Isobutano 1 & 0.987 & 0.839 & 1.157 & 2.022 & 3.0 & 1.3398 & 1.3884 \\
\hline $\begin{array}{l}1128 \\
1130\end{array}$ & Isobutanol & 0.986 & 0.834 & 1.22 & 2.92 & 2.1 & 1.3411 & 1.3887 \\
\hline 810 & Isoamy 1 Alcohol & 0.993 & 0.825 & 0.982 & 3.48 & 4.8 & 1.3362 & 1.4009 \\
\hline 128 & $\begin{array}{l}\text { Tributy } 1 \\
\text { Phosphate }\end{array}$ & 0.9967 & 0.9785 & 0.894 & 3.91 & 7.1 & 1.3332 & 1.4169 \\
\hline
\end{tabular}

a Properties given are for mutual1y saturated phases at $25 \mathrm{C}$ and were obtained after completion of a gun.

b In all cases the dispersed phase is indicated - the continuous phase was distilled water.

c A kerosene as received from Central Solvents and Chemicals Co., Chicago, Ill.

d Same kerosene prewashed with caustic and water and then distilled.

e Methyl isobutyl luetone. 


\begin{tabular}{|c|c|c|}
\hline Impeller Diameter & $D$ & it \\
\hline Tank Diameter & $\mathbf{T}$ & ft \\
\hline $\begin{array}{l}\text { Reference Tank Diameter } \\
\quad(6 \text {-inch })\end{array}$ & $\mathrm{T}_{0}$ & $\mathrm{ft}$ \\
\hline Impeller Speed & $\mathbf{N}$ & rps \\
\hline \multicolumn{3}{|l|}{ Density } \\
\hline Field or Continuous Phase & $P \mathrm{~F}$ & $\mathrm{lb} / \mathrm{cu} \mathrm{ft}$ \\
\hline Drop or Discontinuous & & \\
\hline Phase & $P D$ & $\mathrm{lb} / \mathrm{cu} \mathrm{ft}$ \\
\hline Phase Density Difference & $\Delta \rho$ & $\mathrm{lb} / \mathrm{cuft}$ \\
\hline \multicolumn{3}{|l|}{ Viscosity } \\
\hline Field Phase & $\mu_{F}$ & centipoise (lb/ft sec) \\
\hline Drop Phase & $\mu_{D}$ & centipoise (lb/ft sec) \\
\hline Interfacial Tension & $\sigma_{\mathbf{i}}$ & dynes/cm (lb/sec $\left.{ }^{2}\right)$ \\
\hline
\end{tabular}

And the two properties under investigation:

$\begin{array}{lcl}\text { Interfacial Area } & \text { a } & \mathrm{sq} \mathrm{cm} / \mathrm{cu} \mathrm{cm}\left(\mathrm{ft}^{-1}\right) \\ \text { Settling Time } & t & \text { minutes }(\mathrm{sec}) \\ \begin{array}{l}\text { Reference Settling Time } \\ (1 \text { minute) }\end{array} & \mathrm{t}_{0} & \text { minutes (sec) }\end{array}$

In the original analysis it was considered that interfacial area, $a$, and settling time, $t$, could be correlated independently of one another. Consequently a conventional dimensional analysis(17) was made using the first ten of the foregoing quantities and the interfacial area, $a$. The complete set of dimensionless groups chosen was: 


$$
\begin{array}{ll}
\pi_{1}=\mathrm{Da} & \pi_{5}=\frac{\mathrm{D}^{2} \mathrm{~N} \rho_{\mathrm{F}}}{\mu_{\mathrm{D}}} \\
\pi_{2}=\mathrm{D} / \mathrm{T} & \pi_{6}=\rho_{\mathrm{F}} / \rho_{\mathrm{D}} \\
\pi_{3}=\frac{\mathrm{D}^{3} \mathrm{~N}^{2} \rho_{\mathrm{F}}}{\sigma_{\mathrm{i}}} & \pi_{7}=\Delta \rho / \rho_{\mathrm{F}} \\
\pi_{4}=\frac{\mathrm{D}^{2} \mathrm{~N} \rho_{\mathrm{F}}}{\mu_{\mathrm{F}}} & \pi_{8}=\frac{\mathrm{T}}{\mathrm{T}_{0}}
\end{array}
$$

For convenience as a first simplification, groups $\pi_{4}, \pi_{5}$, and $\pi_{6}$ were combined:

$$
\frac{\pi_{4} \mathrm{x} \pi_{6}}{\pi_{5}}=\nu_{\mathrm{D}} / \nu_{\mathrm{F}}
$$

This combination presupposes that the experimental data will be fitted by exponents on $\pi_{4}, \pi_{5}$, and $\pi_{6}$ in the ratio $1:-1: 1$. The simplification can only be justified if the data can be fitted to a correlation by its use. An attempt was then made to correlate the data obtained using as parameters:

$\mathrm{Da}$

A dimensionless measure of the interfacial area

$\mathrm{D} / \mathrm{T}$

The impeller to tank diameter ratio

$\frac{D^{3} N^{2} \rho_{F}}{\sigma_{i}}$

The Weber number - a characterization of the ratio of shear stresses produced by the impeller to the surface forces on the drops produced
$\Delta \rho / \rho_{F}$
A measure of buoyancy
$\nu_{\mathrm{D}} / \nu_{\mathrm{F}}$
The kinematic viscosity ratio
$\mathrm{T} / \mathrm{T}_{0}$
A scale-up ratio 
The data for each system studied were first plotted on logarithmic paper in the form of Da against Weber number as illustrated for the system xylene-water in Figure 17. This plot is typical of every system studied. Each system was consistent within itself in that data for different impellers fell on parallel lines and there was a definite dependence on the $\mathrm{D} / \mathrm{T}$ ratio which would result in a single correlating line for the system. However, between systems the dependence on the $D / T$ ratio, $k$, necessary to bring points for all impellers into a single line varied from 0.75 to 1.4 and the slopes of the lines varied from 0.25 to 0.48 .

It was apparent that the dependence on the $D / T$ ratio increased with increasing Weber number. Consequently for each system the $D / T$ dependence, $k$, was plotted against the average Weber number as shown in Figure 18. Thereafter the data for each system were expressed as a single line by dividing the observed value, $D a$, by the function $(D / T)^{k}$ wherein the value of $k$ is determined for each point from Figure 18.

Next for each system in the 6 -inch tank the value of $\mathrm{Da} /(\mathrm{D} / \mathrm{T})^{\mathrm{k}}$ was determined at a Weber number of 500 and these values were cross plotted on logarithmic paper against the kinematic viscosity ratio, $\nu_{D} / \nu_{E} \cdot A$ straight line with a slope of $1 / 5$ was obtained. Similarly cross plotting against the value of $\Delta \rho / \rho F$ on semi-logarithmic paper, gave a straight line with the equation:

$$
\frac{\mathrm{Da}}{(\mathrm{D} / \mathrm{T})^{\mathrm{K}}}=\mathrm{K} \exp \left(3.6 \Delta \rho / \rho_{\mathrm{F}}\right)
$$




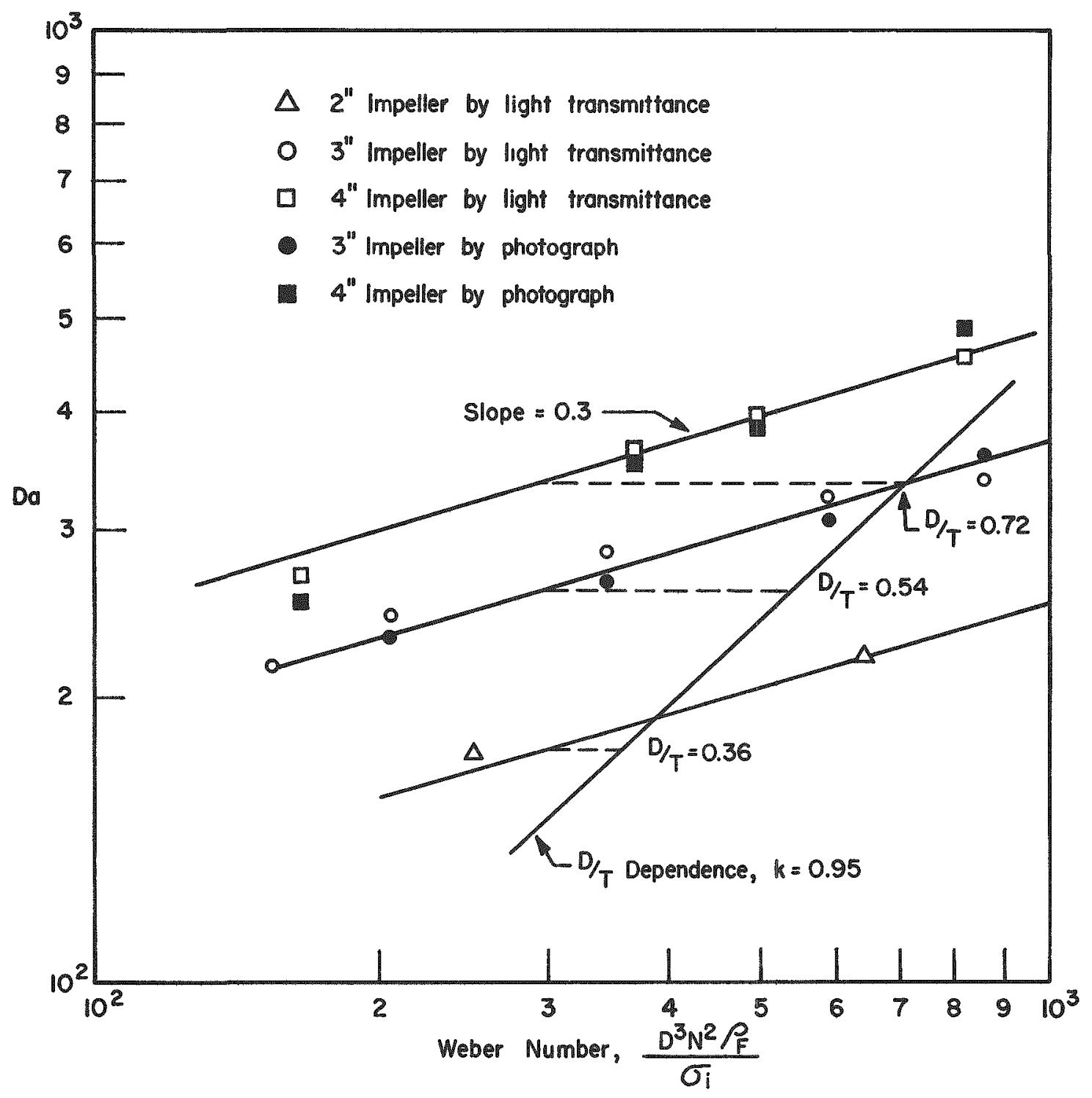

Fig. 17. Illustrative Presentation of Data

Da vs Weber Number

System: Xylene-water Run No. 23

Dispersion: $50 \% \mathrm{O} / \mathrm{W}$ in 6 -inch tank 


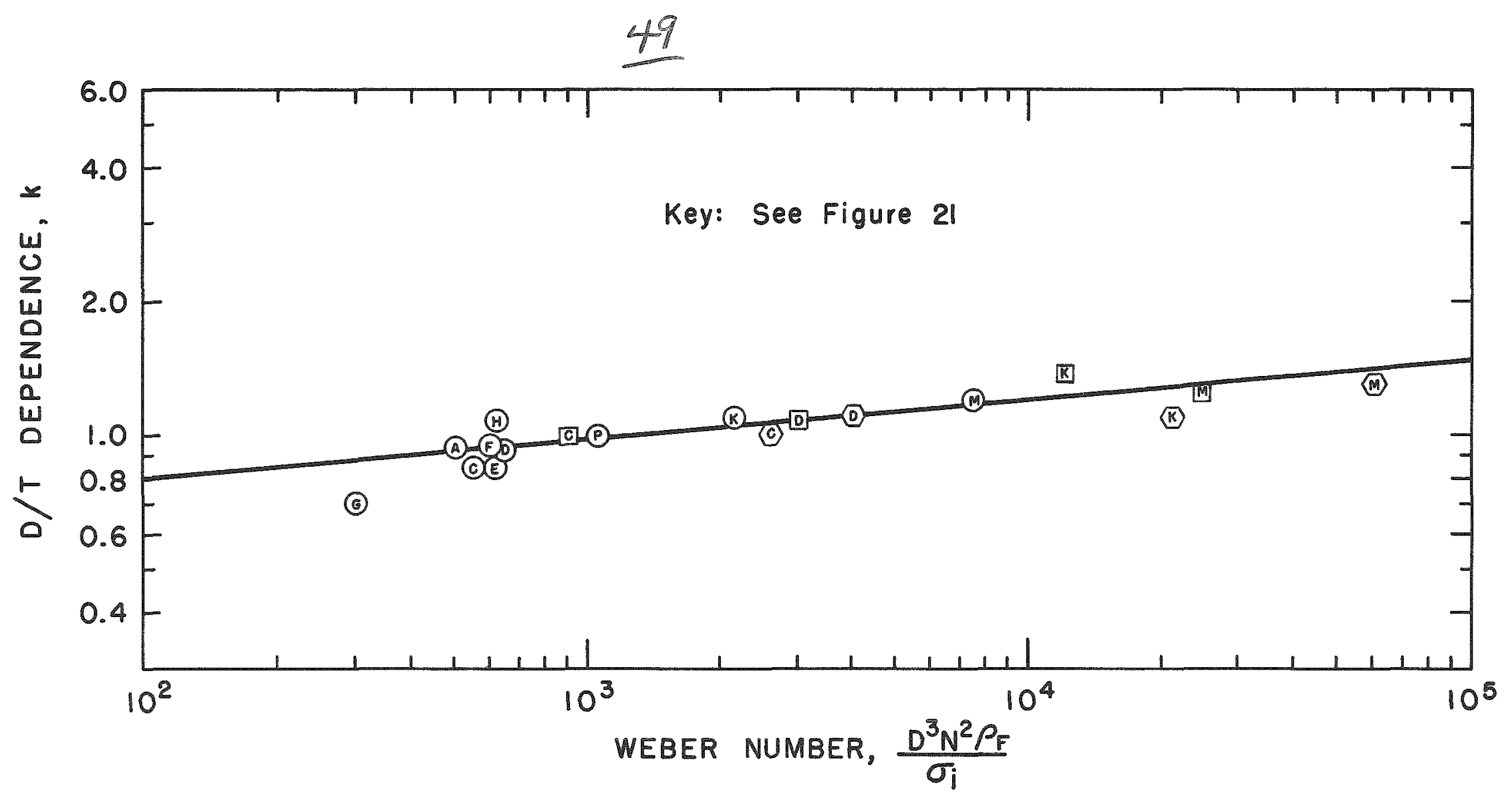

Fig. 18. Variation of $\mathrm{D} / \mathrm{T}$ Dependence

with Mean Weber Number 
All of the data obtained in the 6-inch vessel were then expressed in the form

$$
\frac{\mathrm{Da}}{(\mathrm{D} / \mathrm{T})^{\mathrm{k}}\left(\nu_{\mathrm{D}} / \nu_{\mathrm{F}}\right)^{1 / 5} \exp \left[3.6 \Delta \rho / \rho_{F}\right]}
$$

plotted against the Weber number on logarithmic paper. At this point some considerable scatter remained in the data. It was then noted that all those points which were significantly high had long settling times while those significantly low settled very rapidly. An examination of the data for a number of systems in which contamination had either deliberately or inadvertently been encountered indicated that the inter facial area found increased about as the $1 / 6$ th power of the settling time. The data were therefore normalized to a standard settling time, $t_{0}$ (taken arbitrarily as 1 minute), by dividing the previous quantity by the settling time ratio, $t / t_{0}$, to the $1 / 6$ th power. This procedurebrought all of the 6-inch data into a single correlation with an average deviation equivalent to that of the basic light transmittance correlation.

There remained the determination of the effect of scale up into the larger tanks. For each of the four systems studied in the larger tanks, the quantity

$$
\frac{\mathrm{Da}}{(\mathrm{D} / \mathrm{T})^{\mathrm{k}}\left(\nu_{\mathrm{D}} / \nu_{\mathrm{F}}\right)^{1 / 5} \exp \left(3.6 \Delta \rho / \rho_{\mathrm{F}}\right)\left(\mathrm{t} / \mathrm{t}_{\mathrm{Q}}\right)^{1 / 6}}
$$

was plotted against the Weber number on logarithmic paper. The value for the settling time in the larger tanks was corrected to an equivalent 6-inch settling time. A typical result for the system Amsco-water is shown in Figure 19. The value of this quantity at a Weber number of 
51

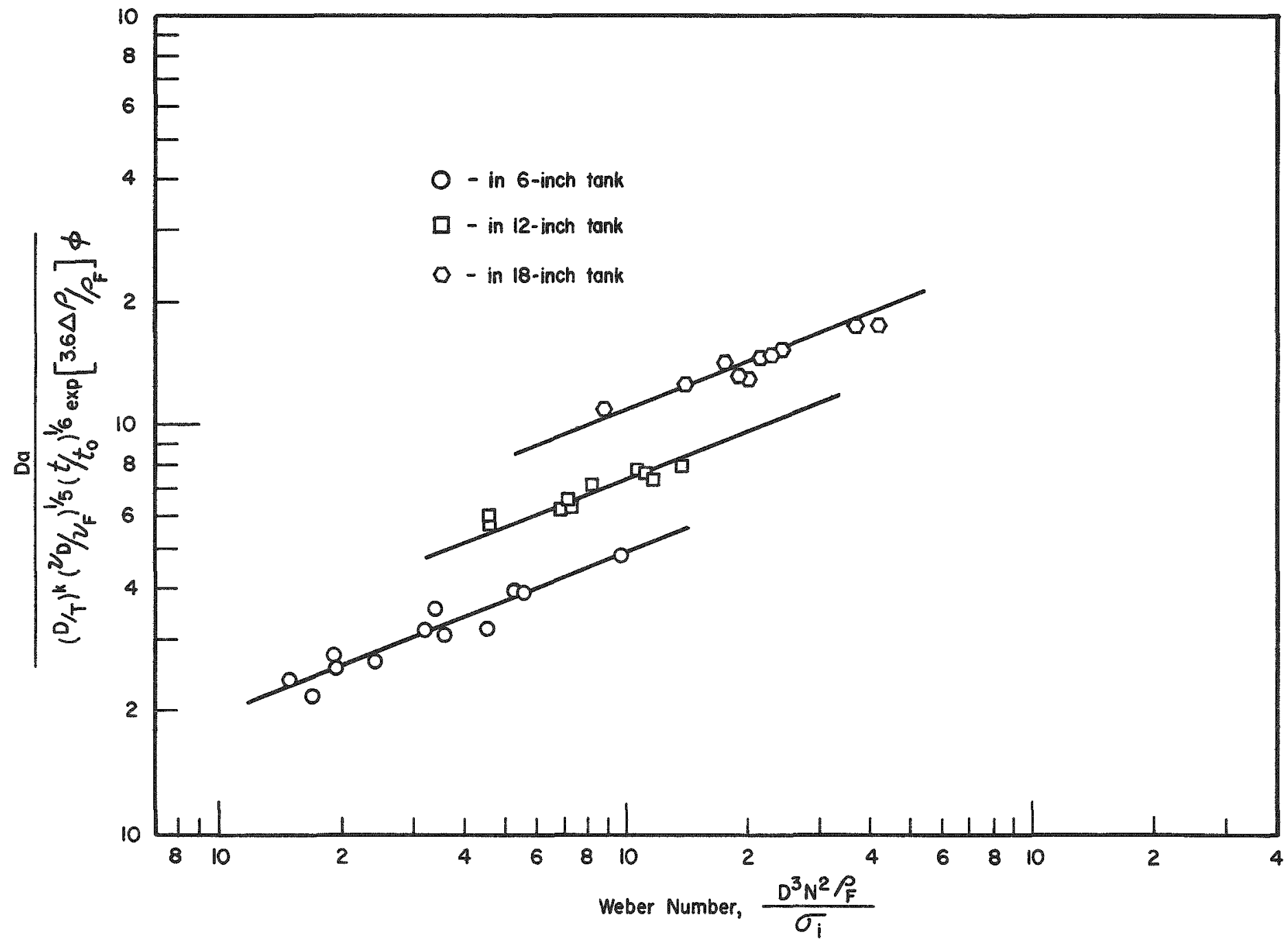

Fig. 19. Illustrative Scale Up Data 
1000 (extrapolated if necessary) was then plotted for each of the four systems against the scale-up ratio, $T / T_{0}$. This is shown in Figure 20 . Since these data give a reasonably straight line on semi-logarithmic paper, the scale-up dependence is also exponential and has the equation:

$$
\phi=0.71 \exp \left(0.35 \mathrm{~T} / \mathrm{T}_{0}\right)
$$

The scale-up factor, $\phi$, equals 1.46 for the 12 -inch tank and 2.15 for the 18 -inch tank.

All of the data correlated in this way are shown in Figure 21 as a logarithmic plot of

$$
\frac{\mathrm{Da}}{(\mathrm{D} / \mathrm{T})^{\mathrm{k}}\left(\nu_{\mathrm{D}} / \nu_{\mathrm{F}}\right)^{1 / 5} \exp \left(3.6 \Delta \rho / \rho_{F}\right)\left(\mathrm{t} / \mathrm{t}_{0}\right)^{1 / 6} \phi}
$$

against the Weber number. The data for 17 systems in three sizes of tanks, a total of 244 determinations, are expressed as a straight line with a slope of 0.36 . The average deviation based on interfacial area is 6.3 per cent, equivalent to the average deviation of the light trans mittance correlation. The maximum deviation (one point) is 28 per cent; all except three points are within 20 per cent.

The necessity for including the settling time in this correlation is regrettable since this requires the knowledge of a property which can only be measured in the experimental apparatus. It may be estimated, but only approximately, by a bottle shake test. About 80 per cent of the data (those settling between 0.2 and 3 minutes) are shown in Figure 22 with the settling time term omitted. Since this results in a considerable increase in the scatter of the data the correlation 


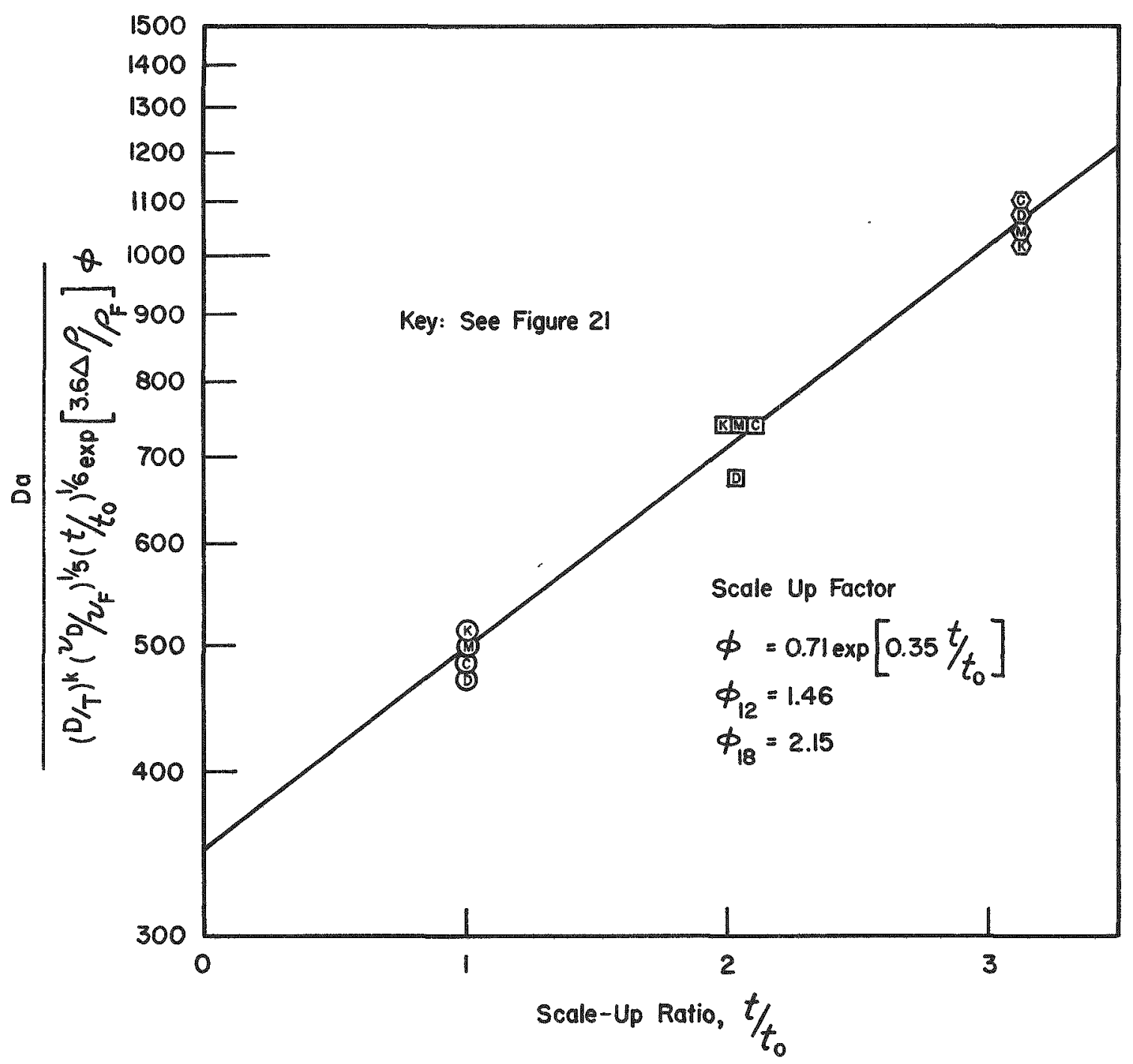

Fig. 20. Scale Up Data 
34

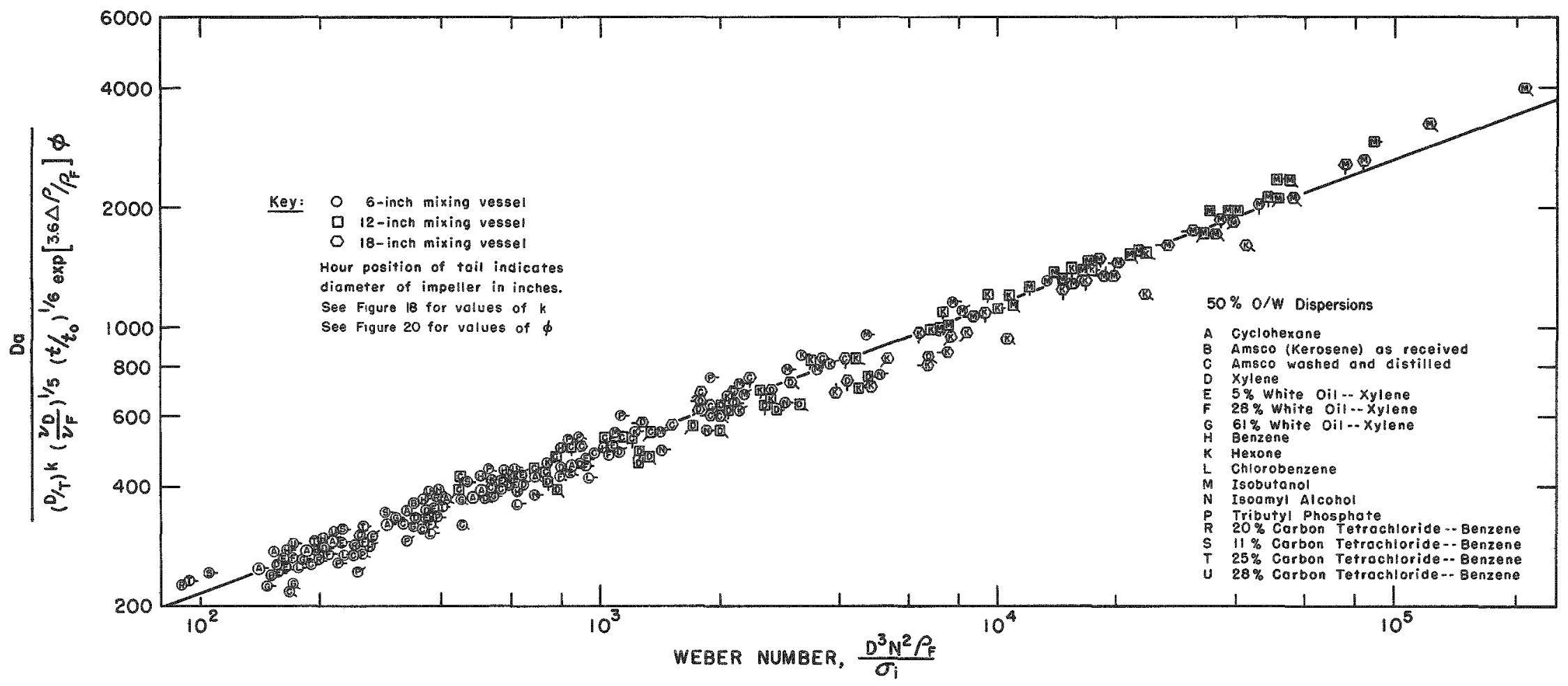

Fig. 21. Generalized Correlation of Interfacial Area with Weber Number 


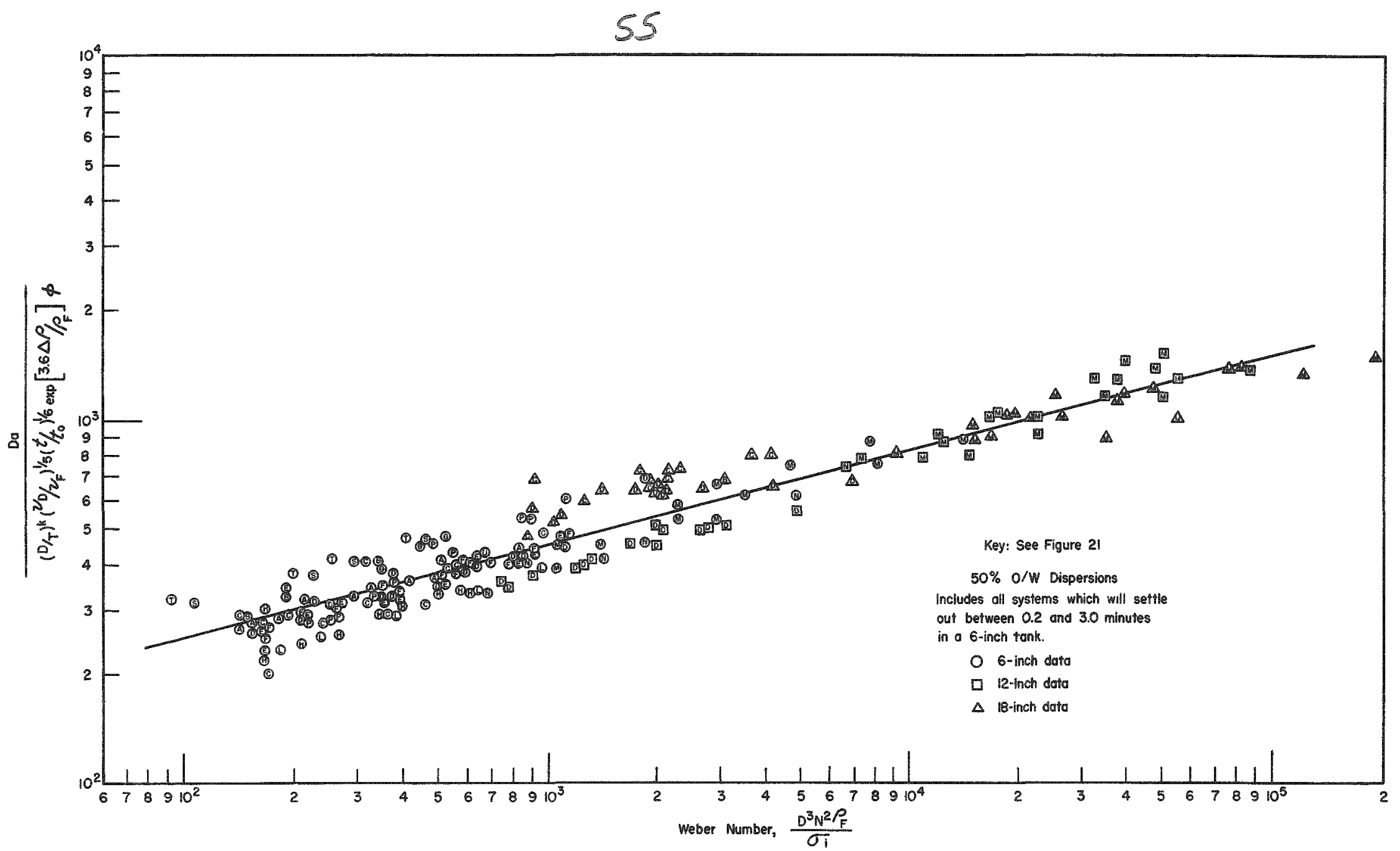

Fig. 22. Simplified Correlation of Interfacial Area with Weber Number 
is further simplified by the use of an average value for $k(1.0)$. In this case the average deviation is 12 per cent and the maximum deviation (same poor point) is 55 per cent. All but seven of the points are within 30 per cent. 


\section{CHAPTER VI \\ DISCUSSION OF DATA}

The correlations presented in Figures 21 and 22 were arrived at by the methods of dimensional analysis and cross plotting and are empirical representations of the data. The data have been obtained carefully and are believed to be accurate to within 10 per cent. Sufficient data have been taken over wide enough ranges of variables that the correlations are felt to be real and not fortuitous. The cor relations were originally worked out for a dozen systems and the remaining ones, including some farthest from the norm $(e . g$. the benzene-carbon tetrachloride mixtures with low $\frac{\Delta \rho}{\rho_{F}}$ and isobutanol in the 18-inch tank--with the highest Weber numbers), were taken later. The data cover the following ranges:

$\begin{array}{lll}\text { Weber No., } \frac{D^{3} N^{2} \rho}{\sigma_{i}} & & 90--200,000 \\ \begin{array}{l}\text { Kinematic Viscosity } \\ \text { Ratio, }\end{array} & \frac{\nu_{D}}{\nu_{F}} & 0.75--9.5 \\ \begin{array}{l}\text { Density Difference } \\ \text { Factor, }\end{array} & \frac{\Delta \rho}{\rho_{F}} & 0.018-0.22 \\ \begin{array}{l}\text { Impeller Diameter } \\ \text { Impeller Speed }\end{array} & \mathrm{D} & 2-12 \text { inches } \\ \text { Tank Diameter } & \mathrm{N} & 1--20 \text { rps }\end{array}$

The greatest weakness of the general correlation (Figure 21) lies in the fact that it was necessary to include the settling time. The correlation shown in Figure 22 can be used, amitting the settling time factor, for systems which settle in between 0.2 and 3 minutes but the 
average deviation is almost twice as large. An effort was made to develop a simple bottle shake test which would serve as a means of predicting the settling time in the tank. This effort was not completely successful. A few systems, in particular Amsco, could not be made to fit such a correlation.

The settling time is believed to represent a measure of the amount of surface active contamination present. Although stringent efforts (described previously) were taken to keep the systems clean, some systems could not be purified in the first place, and in other cases contamination was inadvertently introduced during the course of a run. The presence of contamination was easily noted visually. It was always accompanied by a dull grey film at the interface. Clean systems give interfaces which are highly reflective. At no time was there sufficient change in any physical property, except settling time, to account for the observed change in interfacial area. The settling time is used, therefore, as the only measure so far discovered to characterize the effect of surface active contamination. The exponent (1/6) for the settling time ratio was determined in a series of experiments in which contamination was deliberately courted. The results of these tests are presented in the Appendix, Table 11.

Since this is an empirical correlation, it is unwise and unwarranted to draw firm theoretical conclusions from it. It is interesting, however, to consider the predicted changes in interfacial area with changes in the various controllable geometric and physical factors studied. These effects are summarized in Table 3. 
Table 3. Summary of Effects Predicted by

Generalized Correlation (Figure 21)

\section{Relationship:}

$$
a=\frac{K}{D}\left[\frac{D^{3} N^{2} \rho_{F}}{\sigma_{i}}\right]^{0.36}\left(\frac{D}{T}\right)^{k}\left(\frac{\nu_{D}}{\nu_{F}}\right)^{1 / 5}\left(\frac{t}{t_{0}}\right)^{1 / 6} \exp \left[3.6 \frac{\Delta \rho}{\rho_{F}}\right] \phi
$$

See $F$ igure 18 for values of $k$

See Figure 20 for values of $\phi$

\begin{tabular}{|c|c|c|}
\hline Increase & Relationship & Effect on a \\
\hline Weber Number & $a \sim W e^{0.36}$ & increases \\
\hline a) by increasing $N$ & & increases with $\mathrm{N}^{0.72}$ \\
\hline b) by decreasing $\sigma_{\mathfrak{i}}$ & & increases as $\sigma_{i}=0.36$ \\
\hline c) by increasing $D$ & $a \sim D^{k+0.08}$ & $\begin{array}{l}\text { increases nearly directly } \\
\text { with D and effect is } \\
\text { larger with increasing } \\
\text { Weber Number. }\end{array}$ \\
\hline $\begin{array}{l}\text { Kinematic Viscosity } \\
\text { Ratio }\end{array}$ & $a \sim\left(\frac{\nu_{D}}{\nu_{F}}\right)^{1 / 5}$ & increases slowly \\
\hline$\Delta \rho / \rho_{\mathbf{F}}$ & $a \sim \exp \left[3.6 \frac{\Delta \rho}{\rho_{F}}\right]$ & increases exponentially \\
\hline Settling Time & $a \sim\left(\frac{t}{t_{0}}\right)^{1 / 6}$ & increases slowly \\
\hline \multicolumn{3}{|l|}{$\mathrm{D} / \mathrm{T}($ At Const We) } \\
\hline a) by increasing $D$ & $a \sim D^{k-1}$ & $\begin{array}{l}\text { decreases below } W e=500 \\
\text { increases above } W e=500 \\
\text { effect is small }\end{array}$ \\
\hline b) by decreasing $T$ & a $\frac{\phi}{T^{k}}$ & increases \\
\hline
\end{tabular}


Under the conditions of study, a state of dynamic equilibrium between the formation and coalescence of drops is attained. Drop attrition occurs in some manner due to the energy introduced into the system by the impeller. Meanwhile coalescence is taking place throughout the system. If it is assumed that for coalescence of two drops to take place, the drops must approach each other more closely than the scale of turbulent eddys in the system, then as a first approximation it may be considered that the coalescence is independent of the energy input and takes place continually throughout the system, (6) even in the "jet flow" off the blades of the impeller. The system may then be analyzed in terms of those factors which tend to promote turbulence or flow and those which affect the surface forces.

Effect of Weber Number

In the first place it is indicated that the area should increase approximately as the $1 / 3$ power of the Weber number. The Weber number may be considered as a characterization of the ratio of the shear to surface forces in a system. Since the turbulence introduced into the system may reasonably be expected to increase the breakup of the drops, and the surface force represents the major restoring force promoting coalescence, it is reasonable to expect that the area will increase with the Weber number. It is of more interest to examine the method whereby the Weber number is changed. The area increases approximately as the $3 / 4$ power of impeller speed and as the $-1 / 3$ power of interfacial tension. If the change is brought about by changing 
the impeller diameter, two other groups must be considered and the area is found to increase nearly directly with $D$, the effect being somewhat larger at higher Weber numbers due to the effect of the increasing exponent, $k$, on the $\mathrm{D} / \mathrm{T}$ ratio.

\section{Langlois, et al $(20)$ found, in a very similar study of temporary} liquid-liquid emulsions which were 20 and 40 per cent dispersed phase and some gas-liquid systems of much lower dispersed phase fraction, that interfacial area increased as the 0.6 power of the Weber number and as the 1.2 power of impeller speed. They also showed that the area was dependent upon the volume fraction of the dispersed phase and became relatively smaller as the fraction of dispersed phase was increased. Furthermore the effect appears to become sharply exponential at the upper limit of their data (40 per cent). It would not appear unreasonable in comparison of the two sets of data to expect that for the more concentrated dispersions ( 50 per cent) the effect of coalescence would become more pronounced and the dependence upon the Weber number might well be less than that found for more dilute dispersions. Similarly Hinze, (14) using data of Clay(6) obtained on 5 per cent dispersions in the annular space between a stationary and a rotating cylinder, also found that area increased with the 1.2 power of $\mathrm{N}$ and the -0.6 power of $\sigma$. On the other hand Roy and Rushton, (26) working with a 2 per cent, non-coalescing system in a 2 -inch pipe, found that the area increased with the $1 / 3$ power of the Weber number. In this case the range of Weber number covered was small and nearly all the change was produced by changing the velocity of flow. 
Consider that the breakup of drops will take place largely in the volume of the jet flow off the tip of the impeller. The flow produced by an impeller has been found by Rushton (27) to be proportional to the cube of the diameter.

$$
Q \sim \mathrm{ND}^{3} \mathrm{ft}^{3} / \mathrm{sec}
$$

On the other hand the area of flow increases with the square of the diameter since the width of the blade is scaled up with the diameter. Therefore

$$
u \sim \frac{Q}{A} \sim \frac{N D^{3}}{D W} \quad N D f t / \sec
$$

and the velocity head is proportional to $(\mathrm{ND})^{2}$.

$$
H \sim \frac{(N D)^{2}}{2 g} .
$$

If it is assumed that the velocity of the jet flow alone is responsible for the breakup of drops it might be expected that the effect of $D$ and $N$ should be the same. The effect of $D$ is found to be somewhat larger than that of $\mathrm{N}$, however. It would appear reasonable, then, to assume that a good share of the drop breakup occurs at or near the wall of the vessel where the net flow requires a $90^{\circ}$ change in direction toward the top or bottom of the vessel. If this is the case, the controlling factor is the linear velocity near the wall. It has been shown (32) that velocities in a freely expanding jet fall off exponentially with distance from the jet and an analogous situation is expected in this case. Then if the velocity at the impeller tip is doubled by doubling the impeller speed, the velocity at the wall will 
also be doubled. On the other hand, if the tip velocity is doubled by doubling impeller diameter (at constant $N$ ) the velocity at the wall will be considerably more than doubled as the distance from impeller to wall is less. This hypothesis that a considerable portion of the break up of drops takes place near the wall where the flow changes direction is, then, consistent with the observed data. Effect of Kinematic Viscosity Ratio

The predicted effect of viscosity ratio is small. It is in the direction of increasing interfacial area with increasing viscosity ratio. It should be noted that since the continuous phase was in all cases water, the change in viscosity ratio presented is actually a change in dispersed phase viscosity.

Several investigators $(6,31,33,34)$ have studied the effect of viscosity and viscosity ratio on the breakup of drops. This work has been done with definable flow fields, often laminar, under noncoalescing conditions or at least under conditions in which the effect of coalescence is small. All agree that, in the range of viscosity ratios considered in this work, the viscosity effect is small but all indicate that it should be in the direction of smaller interfacial area with increasing drop to field phase viscosity. That this study indicates the reverse implies that increasing the dispersed phase viscosity hinders the coalescence of the drops. 
Effect of $\triangle \rho / \rho F$

The effect of increasing the density difference between the phases is to increase the interfacial area exponentially. An exponential form for this group is to be expected mathematically since it is the only group considered which can go in the limit to zero. It is evident that the relative velocity between the dispersed drops and the field phase will be greater the larger the density difference is. Presumably the effective velocity in producing shear stress and drop bursting is the net velocity difference between phases-not the gross flow of fluid in the impeller jet.

Of course, settling out of the phases would be expected to increase with increasing $\Delta \rho$ and it might appear that this should work for a smaller rather than larger interfacial area. In no case studied, however, even at the lowest values of $\Delta \rho_{0}$ was the separation of phases slower than the coalescence. Since all data were taken with sufficient energy input to produce complete dispersions, the buoyant forces were small in comparison to the shear stresses. The net expected result is an increase in area with density difference. Effect of Settling Time

As indicated previously, it was necessary to include the dispersion settling time in order to correlate all of the data obtained. The only explanation for this so far advanced is that settling time represents the most sensitive quantity available to measure the effect of surface contamination. It has been observed by many investigators 
that the addition of surface active agents promotes emulsification. In fact stable emulsions are seldom possible without the deliberate addition of "emulsifying agents" which are surface active materials. In this study every effort was made to keep surface active materials out of the system. Since very minute quantities of many substances will cause surface contamination, the degree of cleanliness required is most difficult to obtain experimentally. Despite the use of "aseptic" techniques, contamination was sometimes present. Gross contamination was recognized visually by a large increase in settling time and the appearance at the settled interface of a dull gray film. Small amounts of contamination were characterized by a slight increase in setting time and a dulling of the interface. Clean systems exhibited a highly reflective settled interface.

At the begining of the work it was expected that contamination would produce some change in the physical propereses, particularly in the interfacial tension. It was somewhat surprising to find that in no case was sufficient change found even in interfacial tension to account for the observed change in interfacial area. The use of setting time as a measure of this contamination was therefore forced. The factor, $t / t_{0}$, used is dimensionless only in that it represents the normalization of all data to a standard setting time of one minute.

If increased settling time is accepted as a measure of increased contamination, the indicated increase in interfacial area is to be expected from the stabilization of drops and the hinderance of coalescence. 
Effect of D/T Ratio and Scale-up Ratio

The effect of a change in the $D / T$ ratio depends upon the way in which the change is made. If it is brought about by increasing $D$, the effect is that discussed earlier in the section dealing with changes in the Weber number. If the Weber number is maintained constant (say by decreasing N) as $D$ is increased, the effect is small. The interfacial area will decrease a little below a Weber number of 500 and increase somewhat above that point. If on the other hand $T$, the tank diameter, is increased, the interfacial area will decrease. This observed fact also supports the hypothesis that a large part of the breakup of drops occurs at the points near the wall where the flow direction abruptly changes. Here, again, the velocity at which the directional change takes place will be reduced by increasing $T$.

Qualitative Observations

In the course of this work a number of qualitative observations were made which are interesting and perhaps worthy of additional study at a later date. The most interesting of these is the phenomenon of phase inversion.

It was noted that with most systems the stable dispersion at low energy input was $O / W$ but as the energy input was increased the system would invert to $W / O$. This inversion could be detected by a sudden change in reading on the light probe and by observation of the mode of settling when the impeller was stopped (cf. Figure 15). The change to $W / O$ was always accompanied by a change in settling time 
(often large and almost always in the direction of more rapid settling) and by reversal of the phase which was clearer immediately after settling. This phenomenon of change in settling time has been noted previously by Hernandez-Fragoso, (13) Christian, (4) and Oldshue. (22) They referred to this as "critical speed". Only Christian notes the phase inversion and he does not correlate it with the break time.

As the value of $\Delta \rho / \rho_{F}$ was made larger, it became easier to cause the inversion. Systems with $\Delta \rho / \rho_{F}$ values of the order of 0.6 could not be made to produce $O / W$ dispersions unless the position of the impeller was changed. The desired dispersion can generally be forced by locating the impeller completely in the phase which is desired to be continuous.

This phenomenon merits further study. It was not pursued in this investigation because as yet a satisfactory light correlation for interfacial area in W/O systems has not been worked out. This is in turn due to the fact that photographs of W/O dispersions have always shown drops within drops and a proper definition of the interfacial area would be difficult. A photograph of a $W / O$ dispersion exhibiting this effect is shown in Figure 23. This effect is believed to be due to the fact that the $W / O$ dispersions were formed by inverting $O / W$ dis persions and in the inversion process some of the smaller oil drops are trapped inside the newly formed water drops. Some extremely scant photographic evidence for this explanation has been obtained. 


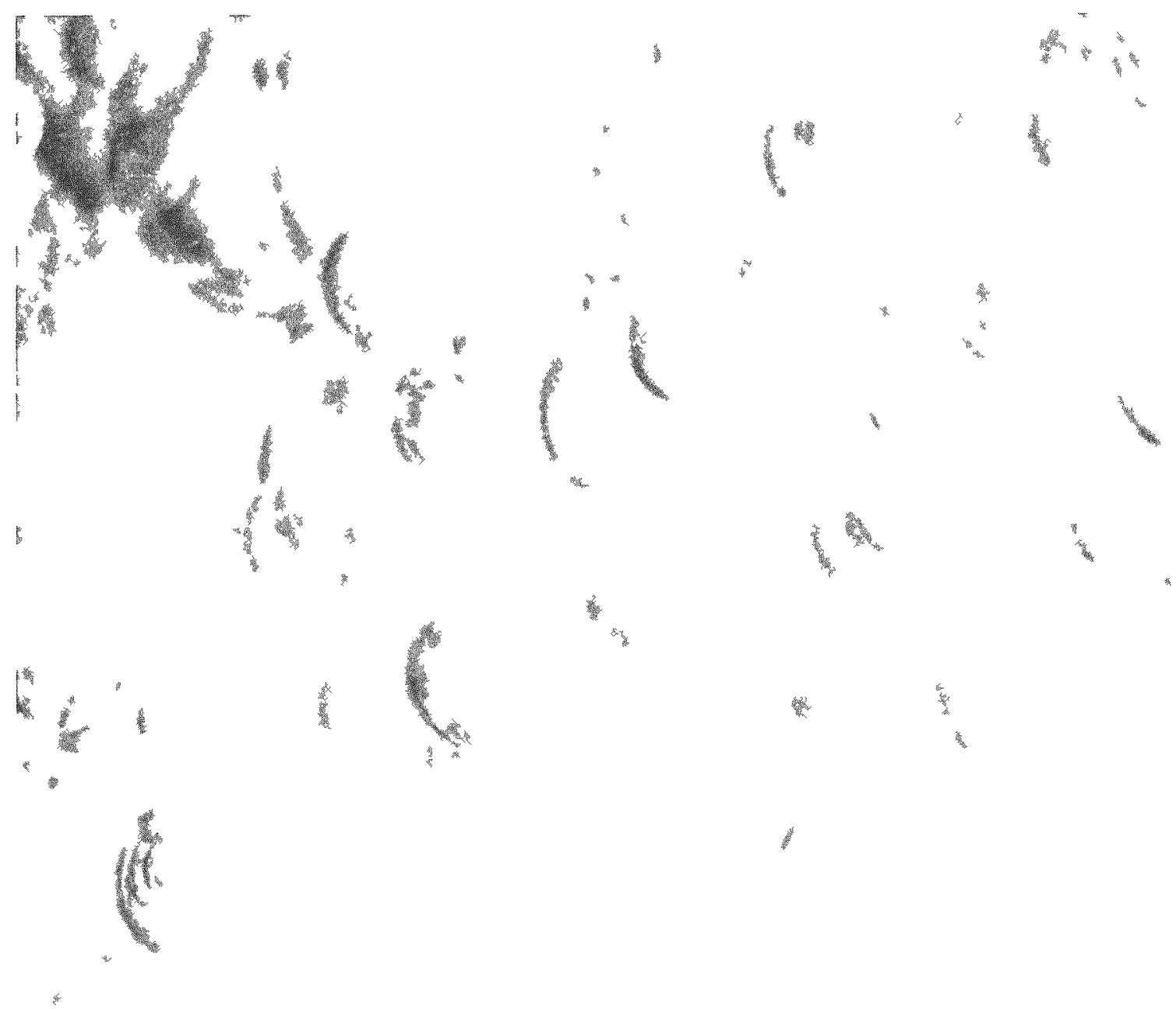

Fig 23. Photograph of W/O Dispersion 
It may be possible to force virgin $W / O$ dispersions by proper location of the impeller. Then if the light-transmission correlation can be extended, this work could also be extended to include W/O dispersions and the point of inversion. Such a study will be difficult to carry out experimentally as the inversion point is hard to reproduce. It appears to be extremely sensitive to the position of the impellex. Since $W / O$ dispersions nearly always settle considerably faster than the $O / W$ dispersions, they would be of considerable commercial interest in the field of solvent extraction since the throughput capacity of contacting equipment should be greater if the oil phase is made the continuous one.

Another factor of interest is the minimum energy required just to produce a complete dispersion. In this work the impeller speed was controlled in increments. The first data were taken at the first increment at which a complete dispersion had been obtained. Thus the data obtained on this point are not sufficiently accurate to correlate the minimum energy requirements. Such a study would be of practical and perhaps theoretical interest. 
(1) A study has been made of interfacial area in immiscible liquid-liquid systems as a function of physical properties and energy input into the system and two methods of measuring interfacial area are presented--one photographic and one making use of light trans mittance.

(2) Data are presented for $17 \mathrm{O} / \mathrm{W}$ systems in three sizes of tanks using a variety of impeller sizes. The data are correlated empirically (see Figure 21) with an average deviation of 6.3 per cent based on area--a deviation equivalent to that of the area-light trans mittance correlation.

(3) While the empirical correlation does not permit of theoretical interpretation, the predicted effects of geometric and physical variables are shown to be logical.

(4) A qualitative observation of the inversion of $\mathrm{O} / \mathrm{W}$ to $\mathrm{W} / \mathrm{O}$ dispersions is noted and the desirability of further study of this phenomenon indicated. 
APPENDIX I

AREA AND SETTLING TIME DATA 


\section{2}

Table 4. Area and Settling Time Data Obtained in $6^{\prime \prime}$ Tank"

\begin{tabular}{|c|c|c|c|c|c|c|c|c|c|c|c|c|}
\hline \multicolumn{2}{|c|}{ Irpeller } & \multicolumn{2}{|c|}{$\begin{array}{c}\text { Interfacial } \\
\text { Area, a, } \\
\text { from }\end{array}$} & \multirow{2}{*}{$\begin{array}{l}\text { Set- } \\
\text { tling } \\
\text { Time } \\
t \\
\text { min }\end{array}$} & \multirow[b]{2}{*}{$\begin{array}{l}\text { Area } \\
\text { Group } \\
\text { Da }\end{array}$} & \multirow{2}{*}{$\begin{array}{c}\begin{array}{c}\text { Weber } \\
\text { No. }\end{array} \\
\frac{D^{3} N^{2} \rho_{F}}{\sigma_{i}}\end{array}$} & \multirow[b]{2}{*}{$\begin{array}{c}\text { Impeller- } \\
\text { Tank } \\
\text { Ratio } \\
\text { D/T }\end{array}$} & \multirow{2}{*}{$\begin{array}{c}D / T \\
\text { Depend- } \\
\text { ence } \\
k\end{array}$} & \multicolumn{2}{|r|}{$\mathrm{Da}^{{ }^{\mathrm{e}, \mathfrak{j}}}$} & \multicolumn{2}{|l|}{ Da ${ }^{e .1}$} \\
\hline $\begin{array}{c}\text { Diam } \\
\text { D } \\
f t\end{array}$ & $\begin{array}{c}\text { Rev } \\
N \\
\sec ^{-1}\end{array}$ & $\underset{\mathrm{cm}^{-1}}{\operatorname{light^{b}}}$ & $\begin{array}{l}\text { photo- } \\
\text { graph } \\
\mathrm{cm}^{-1}\end{array}$ & & & & & & $\left(\frac{D}{T}\right)^{k}\left(\frac{\nu_{D}}{\nu_{F}}\right)^{1 / 5}$ & $\exp \left[3.6 \frac{\Delta \rho}{\rho_{F}}\right]\left(\frac{t}{t_{0}}\right)^{1 / 6}$ & $\left(\frac{\mathrm{D}}{\mathrm{T}}\right)\left(\frac{\nu_{\mathrm{D}}}{\nu_{\mathrm{F}}}\right)^{1 / 5} \exp$ & {$\left[3.6 \frac{\Delta \rho}{\rho_{\mathrm{F}}}\right]$} \\
\hline
\end{tabular}

Run 922 Cyclohexane in Water - Symbol $\mathrm{A}^{\mathrm{h}}$

$\begin{array}{cccccccl}0.167 & 8.98 & 49.3 & 0.76 & 250 & 216 & 0.359 & 0.86 \\ & 13.7 & 61.8 & 0.80 & 315 & 503 & & 0.925 \\ & 17.9 & 68.7 & 0.78 & 350 & 854 & & 0.97 \\ 0.25 & 3.95 & 41.2 & 0.69 & 314 & 141 & 0.54 & 0.82 \\ & 4.50 & 44.6 & 0.72 & 340 & 183 & & 0.84 \\ & 5.67 & 51.0 & 0.76 & 388 & 290 & & 0.88 \\ & 7.30 & 57.7 & 0.78 & 440 & 482 & & 0.92 \\ 0.333 & 2.73 & 43.0 & 0.63 & 435 & 154 & 0.72 & 0.83 \\ & 3.95 & 53.5 & 0.71 & 540 & 324 & & 0.89 \\ & 4.50 & 56.5 & 0.73 & 570 & 412 & & 0.91 \\ & 5.67 & 64.0 & 0.71 & 648 & 690 & & 0.95\end{array}$

Bun 31 Amscof (untreaced) in Water-Symbol B

$\begin{array}{llllll}0.25 & 3.89 & 45.3 & 1.47 & 346 & 151 \\ & 4.38 & 51.8 & & 393 & 192 \\ & 5.66 & 65.5 & & 498 & 340\end{array}$

$\begin{array}{ll}0.54 & 0.83 \\ & 0.845\end{array}$

265
357
413
228
251
293
342
250
318
337
389

291
366
404
242
262
298
338
250
313
329
375

Run 628 Amscog (treated) in water - Symbol C

\begin{tabular}{rrrrrrrl}
0.167 & 9.04 & 42.6 & 0.52 & 217 & 242 & 0.359 & 0.87 \\
& 13.75 & 61.8 & 0.66 & 315 & 560 & & 0.93 \\
& 18.08 & 76.0 & 0.90 & 386 & 970 & & 0.985 \\
0.25 & 4.38 & 37.5 & 0.39 & 285 & 192 & 0.54 & 0.845 \\
& 5.66 & 48.6 & 0.56 & 370 & 320 & & 0.89 \\
& 7.27 & 60.5 & 0.65 & 460 & 528 & & 0.93 \\
0.333 & 2.68 & 31.1 & 0.38 & 315 & 170 & 0.72 & 0.84 \\
& 3.89 & 45.3 & 0.50 & 460 & 359 & & 0.90 \\
& 4.38 & 48.0 & 0.65 & 488 & 456 & & 0.915 \\
\hline
\end{tabular}


Table $4(\text { Continued })^{a}$

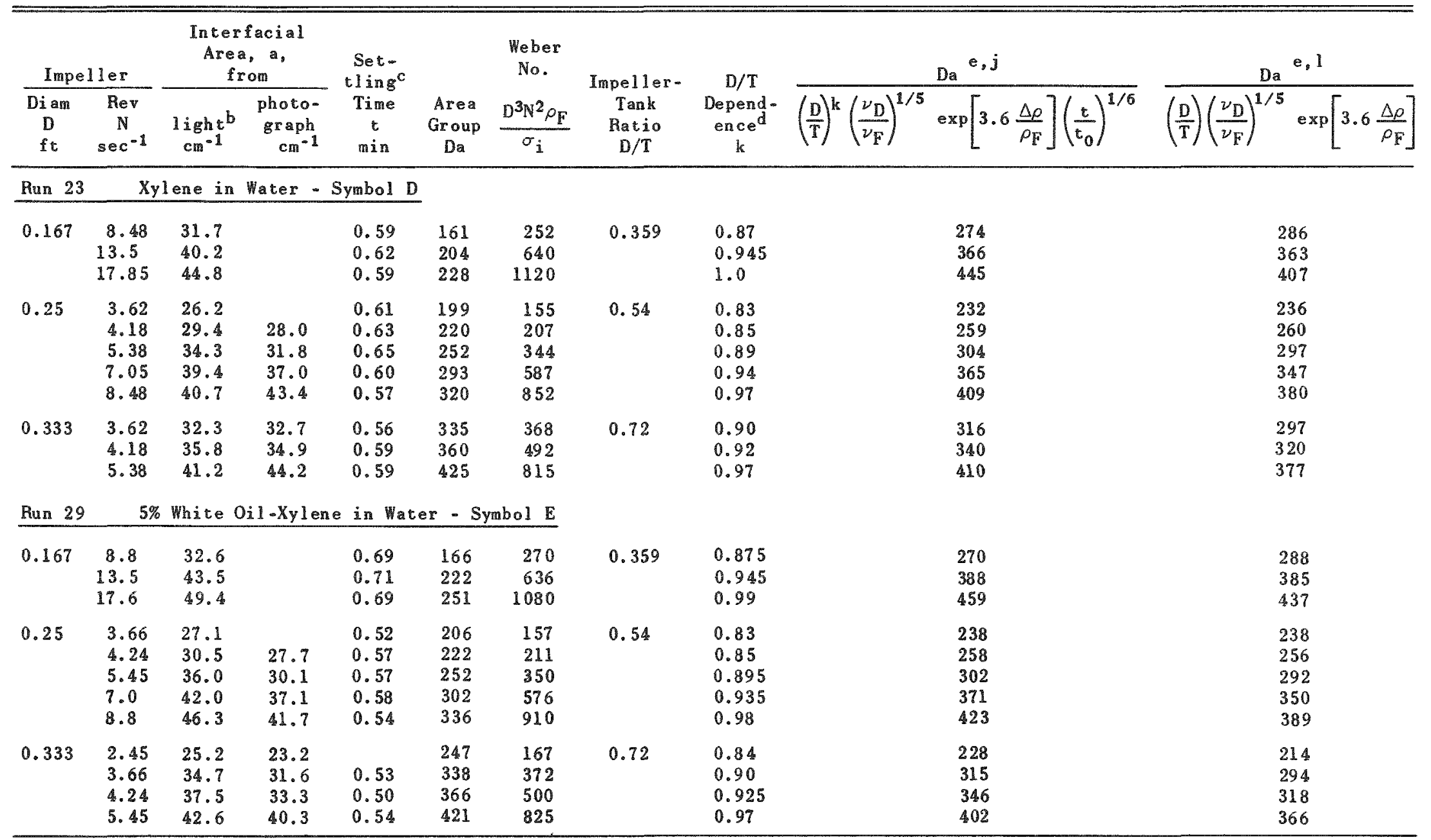




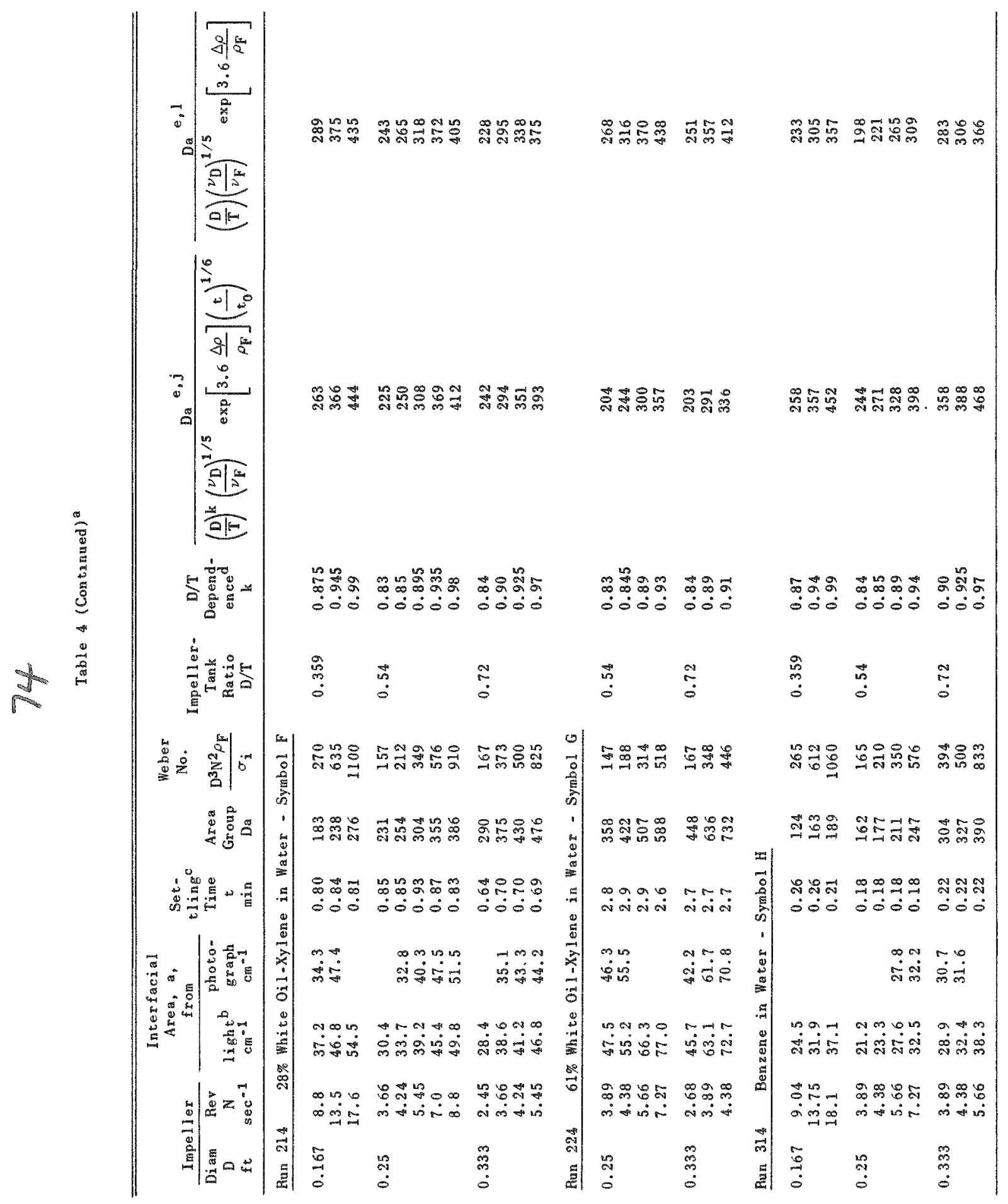


Table 4 (Continued $)^{2}$

\begin{tabular}{|c|c|c|c|c|c|c|c|c|c|c|c|c|}
\hline \multicolumn{2}{|c|}{ Impeller } & \multicolumn{2}{|c|}{$\begin{array}{c}\text { Interfacial } \\
\text { Area, a, } \\
\text { from }\end{array}$} & \multirow{2}{*}{$\begin{array}{c}\text { Set- } \\
\text { tling } \\
\text { Time } \\
\text { t } \\
\min \end{array}$} & \multirow[b]{2}{*}{$\begin{array}{l}\text { Area } \\
\text { Group } \\
\text { Da }\end{array}$} & \multirow{2}{*}{$\begin{array}{c}\text { Weber } \\
\text { No. } \\
\frac{\mathrm{D}^{3} \mathrm{~N}^{2} \rho_{\mathrm{F}}}{\sigma_{\mathrm{i}}}\end{array}$} & \multirow{2}{*}{$\begin{array}{c}\text { Impel ler- } \\
\text { Tank } \\
\text { Patio } \\
\text { D/T }\end{array}$} & \multirow{2}{*}{$\begin{array}{c}D / T \\
\text { Depend- } \\
\text { enced } \\
k\end{array}$} & \multicolumn{2}{|c|}{$\mathrm{Da}{ }^{e, j}$} & \multicolumn{2}{|c|}{ Da $e^{e, 1}$} \\
\hline $\begin{array}{l}\text { Diam } \\
\text { D } \\
\text { ft }\end{array}$ & $\begin{array}{c}\operatorname{Rev} \\
N \\
\sec ^{-1}\end{array}$ & $\underset{\mathrm{cm}^{-1}}{\operatorname{ligh} \mathrm{t}^{\mathrm{b}}}$ & $\begin{array}{l}\text { photo- } \\
\text { graph } \\
\text { cri }^{-1}\end{array}$ & & & & & & $\left(\frac{D}{T}\right)^{k}\left(\frac{\nu_{D}}{\nu_{F}}\right)^{1 / 5} \exp [$ & {$\left[3.6 \frac{\Delta \rho}{\rho_{\mathrm{F}}}\right]\left(\frac{\mathrm{t}}{\mathrm{t}_{0}}\right)^{1 / 6}$} & $\left(\frac{D}{T}\right)\left(\frac{\nu_{D}}{\nu_{F}}\right)^{1 / 5}$ & $\exp \left[3.6 \frac{\Delta \rho}{\nu_{F}}\right]$ \\
\hline
\end{tabular}

Fin 216 Hexone (Methyl Isobutyl Ketone) in Water - Symbol $\mathrm{K}$

\begin{tabular}{|c|c|c|c|c|c|c|c|c|c|c|}
\hline 0.167 & $\begin{array}{r}8.8 \\
13.5 \\
17.6\end{array}$ & $\begin{array}{l}38.9 \\
50.7 \\
60.8\end{array}$ & & $\begin{array}{l}0.11 \\
0.11 \\
0.11\end{array}$ & $\begin{array}{l}198 \\
256 \\
309\end{array}$ & $\begin{array}{r}940 \\
2220 \\
3760\end{array}$ & 0.359 & $\begin{array}{l}0.98 \\
1.06 \\
1.11\end{array}$ & $\begin{array}{l}413 \\
572 \\
745\end{array}$ & $\begin{array}{l}286 \\
370 \\
448\end{array}$ \\
\hline 0.25 & $\begin{array}{l}3.66 \\
4.24 \\
5.45 \\
7.0 \\
8.8\end{array}$ & $\begin{array}{l}31.2 \\
39.1 \\
46.3 \\
54.0 \\
67.6\end{array}$ & $\begin{array}{l}35.0 \\
40.3 \\
45.6 \\
53.3\end{array}$ & $\begin{array}{l}0.10 \\
0.10 \\
0.11 \\
0.11 \\
0.11\end{array}$ & $\begin{array}{l}267 \\
303 \\
350 \\
409 \\
516\end{array}$ & $\begin{array}{r}550 \\
737 \\
1220 \\
2010 \\
3170\end{array}$ & 0.54 & $\begin{array}{l}0.93 \\
0.96 \\
1.00 \\
1.05 \\
1.09\end{array}$ & $\begin{array}{l}366 \\
421 \\
498 \\
603 \\
780\end{array}$ & $\begin{array}{l}258 \\
293 \\
338 \\
393 \\
498\end{array}$ \\
\hline 0.333 & 2.45 & 35.4 & & 0.10 & 361 & 585 & 0.72 & 0.94 & 379 & 261 \\
\hline
\end{tabular}

Run 927 Chlorobenzene in Water - Symbol L

$\begin{array}{llllll}0.25 & 3.95 & 20.7 & 0.37 & 157 & 183 \\ & 4.50 & 22.6 & 0.43 & 172 & 237 \\ & 5.67 & 25.8 & 0.45 & 196 & 376 \\ & 7.30 & 29.5 & 0.50 & 225 & 624 \\ & 8.98 & 34.6 & 0.57 & 263 & 945\end{array}$

$\begin{array}{lll}183 & 0.54 & 0.84 \\ 237 & & 0.86 \\ 376 & & 0.90 \\ 624 & & 0.94 \\ 945 & & 0.98\end{array}$

$\begin{array}{ll}229 & 212 \\ 245 & 231 \\ 286 & 265 \\ 328 & 303 \\ 384 & 355\end{array}$

Run 730 Isobutanol in Water - Symbol $\mathrm{V}$

$\begin{array}{rrrrrrr}0.167 & 5.67 & 52.4 & 59.4 & & 291 & 1390 \\ & 7.30 & 65.5 & 69.5 & & 343 & 2300 \\ & 8.98 & 74.0 & 79.4 & & 392 & 3490 \\ & 13.70 & 95.2 & & & 485 & 8100 \\ & 17.9 & 111.0 & & 0.33 & 563 & 13.850 \\ 0.25 & 2.73 & 58.1 & 58.5 & & 443 & 1080 \\ & 3.95 & 75.2 & 72.3 & & 562 & 2275 \\ & 4.50 & 80.5 & 75.0 & & 613 & 2950 \\ & 5.67 & 95.2 & & & 727 & 4660 \\ & 7.30 & 111.0 & & 0.38 & 846 & 7750\end{array}$

$\begin{array}{ll}0.359 & 1.01 \\ & 1.065 \\ & 1.10 \\ & 1.16 \\ & 1.235 \\ 0.54 & 1.00 \\ & 1.06 \\ & 1.085 \\ & 1.12 \\ & 1.17\end{array}$

495
622
714
1010
1220
497
668
723
878
1055

412
487
557
686
800

420
531
578
687
800


Table 4 (Continued) $^{2}$

\begin{tabular}{|c|c|c|c|c|c|c|c|c|c|c|}
\hline \multicolumn{2}{|c|}{ Impeller } & \multicolumn{2}{|c|}{$\begin{array}{c}\text { Interfacial } \\
\text { Area, a, } \\
\text { from }\end{array}$} & \multirow{2}{*}{$\begin{array}{l}\text { Set- } \\
\text { tling } \\
\text { Time } \\
t \\
\min \end{array}$} & \multirow[b]{2}{*}{$\begin{array}{l}\text { Area } \\
\text { Group } \\
\text { Da }\end{array}$} & \multirow{2}{*}{$\begin{array}{c}\begin{array}{c}\text { Weber } \\
\text { No. }\end{array} \\
\frac{\mathrm{D}^{3} \mathrm{~N}^{2} \rho_{\mathrm{F}}}{\sigma_{\mathrm{i}}}\end{array}$} & \multirow{2}{*}{$\begin{array}{c}\text { Impelles- } \\
\text { Tank } \\
\text { Ratio } \\
\text { D/T }\end{array}$} & \multirow{2}{*}{$\begin{array}{l}D / T \\
\text { Depend- } \\
\text { ence } \\
k\end{array}$} & $\mathrm{Da}{ }^{e, j}$ & $D_{2}^{e, 1}$ \\
\hline $\begin{array}{l}\text { Diam } \\
\text { D } \\
\text { ft }\end{array}$ & $\begin{array}{c}\operatorname{Rev} \\
N \\
\sec ^{-1}\end{array}$ & $\operatorname{light}_{\mathrm{cm}^{-1}}$ & $\begin{array}{l}\text { photo- } \\
\mathrm{graph}^{-1}\end{array}$ & & & & & & $\left(\frac{\mathrm{D}}{\mathrm{T}}\right)^{\mathrm{k}}\left(\frac{\nu_{\mathrm{D}}}{\nu_{\mathrm{F}}}\right)^{1 / 5} \exp \left[3.6 \frac{\Delta_{\rho}}{\rho_{\mathrm{F}}}\right]\left(\frac{t}{t_{0}}\right)^{1 / 6}$ & $\left(\frac{\mathrm{D}}{\mathrm{T}}\right)\left(\frac{\nu_{\mathrm{D}}}{\nu_{\mathrm{F}}}\right)^{1 / 5} \exp \left[3.6 \frac{\Delta \rho}{\rho_{\mathrm{F}}}\right.$ \\
\hline \multicolumn{11}{|c|}{ Run 810} \\
\hline 0.25 & $\begin{array}{l}2.73 \\
3.95 \\
4.50 \\
5.67 \\
7.30\end{array}$ & $\begin{array}{l}52.5 \\
65.8 \\
73.5 \\
83.3 \\
96.2\end{array}$ & & $\begin{array}{l}0.40 \\
0.43 \\
0.42 \\
0.42 \\
0.38\end{array}$ & $\begin{array}{l}400 \\
502 \\
558 \\
635 \\
732\end{array}$ & $\begin{array}{r}680 \\
1430 \\
1850 \\
2930 \\
4875\end{array}$ & 0.54 & $\begin{array}{l}0.95 \\
1.02 \\
1.04 \\
1.08 \\
1.12\end{array}$ & $\begin{array}{l}343 \\
445 \\
504 \\
586 \\
695\end{array}$ & $\begin{array}{l}302 \\
380 \\
421 \\
480 \\
553\end{array}$ \\
\hline \multicolumn{2}{|c|}{ Pun 128} & ibutyl $\mathrm{Pl}$ & hosphate & in Water & \multicolumn{2}{|c|}{ - Symbol P } & & & & \\
\hline 0.167 & $\begin{array}{l}3.66 \\
4.24 \\
5.45\end{array}$ & & $\begin{array}{l}25.9 \\
30.3 \\
40.6\end{array}$ & $\begin{array}{l}0.90 \\
0.90 \\
0.90\end{array}$ & $\begin{array}{l}132 \\
154 \\
206\end{array}$ & $\begin{array}{l}248 \\
331 \\
549\end{array}$ & 0.359 & $\begin{array}{l}0.87 \\
0.89 \\
0.93\end{array}$ & $\begin{array}{l}223 \\
266 \\
372\end{array}$ & $\begin{array}{l}254 \\
296 \\
398\end{array}$ \\
\hline 0.25 & $\begin{array}{l}1.88 \\
2.45 \\
3.66 \\
4.24 \\
5.45\end{array}$ & & $\begin{array}{l}25.9 \\
33.4 \\
50.3 \\
56.2 \\
69.2\end{array}$ & $\begin{array}{l}1.00 \\
1.00 \\
1.00 \\
1.00 \\
1.00\end{array}$ & $\begin{array}{l}198 \\
254 \\
382 \\
428 \\
527\end{array}$ & $\begin{array}{r}221 \\
374 \\
835 \\
1120 \\
1850\end{array}$ & 0.54 & $\begin{array}{l}0.86 \\
0.90 \\
0.97 \\
1.00 \\
1.04\end{array}$ & $\begin{array}{l}234 \\
308 \\
484 \\
548 \\
695\end{array}$ & $\begin{array}{l}254 \\
328 \\
494 \\
553 \\
682\end{array}$ \\
\hline 0.333 & $\begin{array}{l}1.31 \\
1.88 \\
2.45\end{array}$ & & $\begin{array}{l}26.3 \\
42.7 \\
49.7\end{array}$ & $\begin{array}{l}1.00 \\
1.00 \\
1.00\end{array}$ & $\begin{array}{l}268 \\
437 \\
508\end{array}$ & $\begin{array}{l}254 \\
523 \\
887\end{array}$ & 0.72 & $\begin{array}{l}0.87 \\
0.93 \\
0.975\end{array}$ & $\begin{array}{l}247 \\
408 \\
485\end{array}$ & $\begin{array}{l}259 \\
421 \\
490\end{array}$ \\
\hline Run 75 & 20 & Carbon & Tetrach 1 & loride-Be & enzene & in Water & - Symbol R & & & \\
\hline 0.25 & $\begin{array}{l}2.73 \\
3.95 \\
4.50 \\
5.67\end{array}$ & & $\begin{array}{l}21.0 \\
23.1 \\
25.2 \\
32.6\end{array}$ & 4.0 & $\begin{array}{l}178 \\
215 \\
231 \\
257\end{array}$ & $\begin{array}{r}90 \\
193 \\
250 \\
395\end{array}$ & 0.54 & $\begin{array}{l}0.79 \\
0.845 \\
0.87 \\
0.905\end{array}$ & $\begin{array}{l}206 \\
237 \\
263 \\
345\end{array}$ & $\begin{array}{l}331 \\
398 \\
430 \\
476\end{array}$ \\
\hline
\end{tabular}


Table 4 (Continued $)^{2}$

\begin{tabular}{|c|c|c|c|c|c|c|c|c|c|c|c|}
\hline \multicolumn{2}{|c|}{ Impel ler } & \multicolumn{2}{|c|}{$\begin{array}{l}\text { Interfacial } \\
\text { Area, a, } \\
\text { from }\end{array}$} & \multirow{2}{*}{$\begin{array}{l}\text { Set- } \\
\text { tling } \\
\text { Time } \\
t \\
\min \end{array}$} & \multirow[b]{2}{*}{$\begin{array}{c}\text { Area } \\
\text { Group } \\
\text { Da }\end{array}$} & \multirow{2}{*}{$\begin{array}{c}\begin{array}{c}\text { Weber } \\
\text { No. }\end{array} \\
\frac{\mathrm{D}^{3} \mathrm{~N}^{2} \rho_{\mathrm{F}}}{\sigma_{\mathrm{i}}}\end{array}$} & \multirow[b]{2}{*}{$\begin{array}{l}\text { Impeller- } \\
\text { Tank } \\
\text { Ratio } \\
\text { D/T }\end{array}$} & \multirow[b]{2}{*}{$\begin{array}{l}\mathrm{D} / \mathrm{T} \\
\text { Depend - } \\
\text { enced } \\
\mathrm{k}\end{array}$} & $\mathrm{Da}^{e, j}$ & \multicolumn{2}{|l|}{$\mathrm{Da}^{e, 1}$} \\
\hline $\begin{array}{l}\text { Diam } \\
\text { D } \\
\mathrm{ft}\end{array}$ & $\begin{array}{c}\text { Rev } \\
\sec ^{-1}\end{array}$ & $\underset{\mathrm{cm}^{-1}}{\operatorname{light} b}$ & $\begin{array}{l}\text { photo- } \\
\mathrm{graph}_{\mathrm{cm}}^{-1}\end{array}$ & & & & & & $\left(\frac{\mathrm{D}}{\mathrm{T}}\right)^{\mathrm{k}}\left(\frac{\nu_{\mathrm{D}}}{\nu_{\mathrm{F}}}\right)^{1 / 5} \exp \left[3.6 \frac{\Delta \rho}{\rho_{\mathrm{F}}}\right]\left(\frac{\mathrm{t}}{\mathrm{t}_{0}}\right)^{1 / 6}$ & $\left(\frac{D}{T}\right)\left(\frac{\nu_{D}}{\nu_{F}}\right)^{1 / 5} \exp$ & {$\left[3.6 \frac{\Delta \rho}{\rho_{\mathrm{F}}}\right]$} \\
\hline Run 727 & 11 & Carbon & Tetracl & 1 onida & Benzere & in Water & - Symbol $\mathrm{S}$ & & & & \\
\hline 0.25 & $\begin{array}{l}2.73 \\
3.95 \\
4.50 \\
5.67\end{array}$ & $\begin{array}{l}21.5 \\
26.7 \\
28.7 \\
32.9\end{array}$ & & 1.9 & $\begin{array}{l}164 \\
203 \\
219 \\
251\end{array}$ & $\begin{array}{l}107 \\
225 \\
292 \\
465\end{array}$ & 0.54 & $\begin{array}{l}0.805 \\
0.86 \\
0.88 \\
0.92\end{array}$ & $\begin{array}{l}224 \\
288 \\
313 \\
367\end{array}$ & $\begin{array}{l}282 \\
348 \\
375 \\
430\end{array}$ & \\
\hline Run 728 & 25 & $\%$ Carbon & Tetrach & loride $-B$ & Benzene & in Water & - Symbol T & & & & \\
\hline 0.25 & $\begin{array}{l}2.73 \\
3.95 \\
4.50 \\
5.67\end{array}$ & $\begin{array}{l}22.9 \\
27.1 \\
29.3 \\
33.4\end{array}$ & & 3.3 & $\begin{array}{l}174 \\
206 \\
224 \\
254\end{array}$ & $\begin{array}{r}93 \\
197 \\
255 \\
404\end{array}$ & 0.54 & $\begin{array}{l}0.79 \\
0.85 \\
0.87 \\
0.905\end{array}$ & $\begin{array}{l}210 \\
258 \\
286 \\
330\end{array}$ & $\begin{array}{l}295 \\
350 \\
381 \\
432\end{array}$ & \\
\hline Bun 28 & 28 & \% Carbon & Tetrach & loride $-B$ & Benzene & in Water & - Symbol U & & & & \\
\hline 0.25 & $\begin{array}{l}3.58 \\
4.15 \\
5.37 \\
7.00\end{array}$ & $\begin{array}{l}24.0 \\
27.4 \\
31.3 \\
34.2\end{array}$ & $\begin{array}{l}19.6 \\
24.0 \\
29.4 \\
32.2\end{array}$ & 0.78 & $\begin{array}{l}183 \\
196 \\
231 \\
254\end{array}$ & $\begin{array}{l}163 \\
219 \\
368 \\
625\end{array}$ & 0.54 & $\begin{array}{l}0.835 \\
0.86 \\
0.90 \\
0.94\end{array}$ & $\begin{array}{l}256 \\
279 \\
337 \\
380\end{array}$ & $\begin{array}{l}274 \\
293 \\
346 \\
380\end{array}$ & \\
\hline
\end{tabular}

Data are for 50 per cent $0 / W$ dispersions at $25 \mathrm{C}$.

Supporting data given in Table 7 .

Settling time taken from instant stirrer is stopped to first appearance of clear interface.

d A function of Weber Number shown in Figure 18.

Values of correlating physical parameters given in Table 10.

f A kerosene as received from Central Solvents and Chemicals Co., Chicago, Ill.

g Same kerosene prewashed with caustic and water and then distilled.

Used in correlating plots, Figures 18,20,21, and 22

$j$ Data used in correlation shown in Figure 21.

1 Data used in correlation shown in Figure 22. 
Table 5. Area and Settling Time Data Obtained in $12^{\text {" Tank }}$

\begin{tabular}{|c|c|c|c|c|c|c|c|c|c|c|}
\hline \multicolumn{2}{|c|}{ Impeller } & \multirow{2}{*}{$\begin{array}{c}\text { Inter- } \\
\text { facial } \\
\text { Area, a, } \\
\text { from } \\
\text { light } \\
\text { cmol }^{-1}\end{array}$} & \multirow{2}{*}{$\begin{array}{c}\text { Set- } \\
\text { ting } \\
\text { Time } \\
\text { t } \\
\text { min }\end{array}$} & \multirow[b]{2}{*}{$\begin{array}{l}\text { Area } \\
\text { Group } \\
\text { Da }\end{array}$} & \multirow{2}{*}{$\begin{array}{c}\text { Weber } \\
\text { No. } \\
\frac{D^{3} N^{2} \rho_{F}}{\sigma_{i}}\end{array}$} & \multirow[b]{2}{*}{$\begin{array}{c}\text { Impeller- } \\
\text { Tank } \\
\text { Ratio } \\
\text { D/T }\end{array}$} & \multirow{2}{*}{$\begin{array}{l}\mathrm{D} / \mathrm{T} \\
\text { Depend- } \\
\text { ence } \mathrm{d} \\
k\end{array}$} & \multicolumn{2}{|c|}{$\mathrm{Da}^{\mathrm{e}, \mathrm{f}, \mathrm{h}}$} & $D_{a}{ }^{e, f, j}$ \\
\hline $\begin{array}{c}\text { Diam } \\
\text { D } \\
i t\end{array}$ & $\begin{array}{c}\text { Rev } \\
\sec ^{-1}\end{array}$ & & & & & & & $\left(\frac{\mathrm{D}}{\mathrm{T}}\right)^{\mathrm{k}}\left(\frac{\nu_{\mathrm{D}}}{\nu_{\mathrm{F}}}\right)^{1 / 5} \exp$ & $\overline{\left(3.6 \frac{\Delta \rho}{\rho_{\mathrm{F}}}\right)\left(\frac{\mathrm{t}}{\mathrm{t}_{0}}\right)^{1 / 6} \phi}$ & $\left(\frac{\mathrm{D}}{\mathrm{T}}\right)\left(\frac{\nu_{\mathrm{D}}}{\nu_{\mathrm{F}}}\right)^{1 / 5} \exp \left(3.6 \frac{\Delta \rho}{\rho_{\mathrm{F}}}\right) \phi$ \\
\hline
\end{tabular}

Run 1121 Hexone (Methyl Isobutyl Ketone) in Water - Symbol K

\begin{tabular}{rcrrrrrrr}
\hline 0.25 & 10.4 & 41.3 & 0.36 & 315 & 4500 & 0.264 & 1.12 & 645 \\
& 15.5 & 54.2 & 0.36 & 412 & 10000 & & 1.22 & 1015 \\
& 20.5 & 62.7 & 0.36 & 477 & 17600 & & 1.27 & 1260 \\
0.333 & 5.25 & 38.0 & 0.33 & 389 & 2710 & 0.35 & 1.08 & 586 \\
& 6.7 & 48.1 & 0.34 & 491 & 4420 & & 1.12 & 768 \\
& 8.33 & 54.2 & 0.34 & 553 & 6830 & & 1.16 & 906 \\
& 10.4 & 61.1 & 0.34 & 625 & 10640 & & 1.22 & 1090 \\
& 15.5 & 72.3 & 0.34 & 738 & 23650 & & 1.30 & 1400 \\
0.50 & 2.76 & 43.4 & 0.33 & 663 & 2530 & 0.526 & 1.07 & 636 \\
& 3.2 & 51.1 & 0.33 & 781 & 3400 & & 1.10 & 763 \\
& 4.7 & 64.3 & 0.33 & 983 & 7350 & & 1.17 & 1005 \\
& 5.35 & 68.9 & 0.33 & 1050 & 9530 & & 1.20 & 1105 \\
& 6.8 & 78.2 & 0.33 & 1195 & 15400 & & 1.25 & 1290
\end{tabular}

Run 1028 Amscog in Water - Symbol C

\begin{tabular}{rrrrrrrrr}
\hline 0.25 & 8.3 & 63.3 & 6.0 & 482 & 690 & 0.264 & 0.95 & 398 \\
& 10.3 & 77.7 & 8.0 & 593 & 1060 & & 0.99 & 489 \\
0.333 & 5.6 & 63.8 & 7.8 & 652 & 738 & 0.35 & 0.96 & 398 \\
& 6.8 & 81.4 & 12.6 & 831 & 1090 & & 0.99 & 486 \\
0.50 & 2.38 & 51.2 & 3.3 & 782 & 454 & 0.526 & 0.915 & 381 \\
& 3.22 & 72.7 & 8.3 & 1111 & 830 & & 0.97 & 456 \\
& 3.82 & 76.2 & 10.6 & 1165 & 1165 & & 1.00 & 467 \\
0.667 & 1.55 & 50.7 & 3.4 & 1030 & 456 & 0.705 & 0.915 & 366 \\
& 1.95 & 60.7 & 5.1 & 1235 & 722 & & 0.96 & 413 \\
& 2.70 & 84.1 & 12.6 & 1710 & 1385 & & 1.01 & 500
\end{tabular}


Table 5 (Continued) $^{a}$

\begin{tabular}{|c|c|c|c|c|c|c|c|c|c|}
\hline \multicolumn{2}{|c|}{ Impeller } & \multirow{2}{*}{$\begin{array}{c}\text { Inter- } \\
\text { facial } \\
\text { Area, a, } \\
\text { from } \\
\text { light } \\
\mathrm{cm}^{-1}\end{array}$} & \multirow{2}{*}{$\begin{array}{c}\text { Set- } \\
\text { ting } \\
\text { Time } \\
t \\
\text { min }\end{array}$} & \multirow[b]{2}{*}{$\begin{array}{l}\text { Area } \\
\text { Group } \\
\text { Da }\end{array}$} & \multirow{2}{*}{$\begin{array}{c}\begin{array}{c}\text { Weber } \\
\text { No. }\end{array} \\
\frac{D^{3} N^{2} \rho_{F}}{\sigma_{i}}\end{array}$} & \multirow{2}{*}{$\begin{array}{c}\text { Impeller- } \\
\text { Tank } \\
\text { Ratio } \\
\text { D/T }\end{array}$} & \multirow[b]{2}{*}{$\begin{array}{l}\mathrm{D} / \mathrm{T} \\
\text { Depend- } \\
\text { enced } \\
\mathrm{k}\end{array}$} & $D_{2} e_{, f, h}$ & $\mathrm{Da}^{e, f, j}$ \\
\hline $\begin{array}{l}\text { Diam } \\
\text { D } \\
\mathrm{ft}\end{array}$ & $\begin{array}{c}\operatorname{Rev} \\
\sec ^{-1}\end{array}$ & & & & & & & $\overline{\left(\frac{\mathrm{D}}{\mathrm{T}}\right)^{\mathrm{k}}\left(\frac{\nu_{\mathrm{D}}}{\nu_{\mathrm{F}}}\right)^{1 / 5} \exp \left(3.6 \frac{\Delta \rho}{\rho_{\mathrm{F}}}\right)\left(\frac{\mathrm{t}}{\mathrm{t}_{0}}\right)^{1 / 6} \phi}$ & $\overline{\left(\frac{D}{T}\right)\left(\frac{\nu_{D}}{\nu_{F}}\right)^{1 / 5} \exp \left(3.6 \frac{\Delta \rho}{\rho_{F}}\right) \phi}$ \\
\hline \multicolumn{2}{|c|}{ Run 119} & Xylene in & \multicolumn{2}{|c|}{ Water - Symbol D } & & & & & \\
\hline 0.25 & $\begin{array}{l}10.4 \\
15.5 \\
20.5\end{array}$ & $\begin{array}{l}28.4 \\
35.6 \\
39.7\end{array}$ & $\begin{array}{l}0.80 \\
0.85 \\
0.80\end{array}$ & $\begin{array}{l}216 \\
271 \\
302\end{array}$ & $\begin{array}{l}1250 \\
2780 \\
4880\end{array}$ & 0.264 & $\begin{array}{l}1.0 \\
1.08 \\
1.13\end{array}$ & $\begin{array}{l}416 \\
573 \\
686\end{array}$ & $\begin{array}{l}361 \\
452 \\
503\end{array}$ \\
\hline 0.333 & $\begin{array}{c}5.33 \\
6.8 \\
8.5 \\
10.7\end{array}$ & $\begin{array}{l}24.5 \\
28.4 \\
31.8 \\
36.0\end{array}$ & $\begin{array}{l}0.69 \\
0.73 \\
0.74 \\
0.70\end{array}$ & $\begin{array}{l}250 \\
289 \\
324 \\
366\end{array}$ & $\begin{array}{r}780 \\
1270 \\
2000 \\
3150\end{array}$ & 0.35 & $\begin{array}{l}0.965 \\
1.0 \\
1.05 \\
1.09\end{array}$ & $\begin{array}{l}357 \\
427 \\
503 \\
581\end{array}$ & $\begin{array}{l}315 \\
364 \\
407 \\
459\end{array}$ \\
\hline 0.50 & $\begin{array}{l}2.85 \\
3.67 \\
4.75 \\
5.4\end{array}$ & $\begin{array}{l}25.8 \\
29.3 \\
35.6 \\
35.6\end{array}$ & $\begin{array}{l}0.65 \\
0.67 \\
0.60 \\
0.57\end{array}$ & $\begin{array}{l}393 \\
447 \\
542 \\
542\end{array}$ & $\begin{array}{r}750 \\
1250 \\
2090 \\
2700\end{array}$ & 0.526 & $\begin{array}{l}0.96 \\
1.0 \\
1.05 \\
1.10\end{array}$ & $\begin{array}{l}384 \\
445 \\
571 \\
594\end{array}$ & $\begin{array}{l}329 \\
374 \\
453 \\
453\end{array}$ \\
\hline 0.667 & $\begin{array}{l}2.04 \\
2.8 \\
3.04\end{array}$ & $\begin{array}{l}26.8 \\
32.6 \\
36.3\end{array}$ & $\begin{array}{l}0.47 \\
0.50 \\
0.50\end{array}$ & $\begin{array}{l}544 \\
661 \\
737\end{array}$ & $\begin{array}{r}910 \\
1720 \\
2030\end{array}$ & 0.705 & $\begin{array}{l}0.98 \\
1.03 \\
1.05\end{array}$ & $\begin{array}{l}429 \\
521 \\
585\end{array}$ & $\begin{array}{l}338 \\
412 \\
461\end{array}$ \\
\hline \multicolumn{2}{|c|}{ Run 1128} & sobutanol & in water & \multicolumn{2}{|c|}{ I - Symbol M } & & & & \\
\hline 0.25 & $\begin{array}{l}8.45 \\
10.5 \\
15.7 \\
20.6\end{array}$ & $\begin{array}{r}76.2 \\
87.4 \\
112.4 \\
131.5\end{array}$ & $\begin{array}{l}0.57 \\
0.57 \\
0.53 \\
0.50\end{array}$ & $\begin{array}{r}581 \\
664 \\
855 \\
1005\end{array}$ & $\begin{array}{l}14850 \\
23000 \\
51200 \\
88200\end{array}$ & 0.264 & $\begin{array}{l}1.25 \\
1.30 \\
1.39 \\
1.45\end{array}$ & $\begin{array}{l}1215 \\
1480 \\
2140 \\
2705\end{array}$ & $\begin{array}{r}708 \\
814 \\
1045 \\
1225\end{array}$ \\
\hline 0.333 & $\begin{array}{c}4.7 \\
5.33 \\
6.8 \\
8.45 \\
10.6\end{array}$ & $\begin{array}{r}74.3 \\
83.3 \\
97.1 \\
110.5 \\
123.3\end{array}$ & $\begin{array}{l}0.68 \\
0.68 \\
0.68 \\
0.65 \\
0.515\end{array}$ & $\begin{array}{r}757 \\
851 \\
990 \\
1135 \\
1260\end{array}$ & $\begin{array}{l}10900 \\
14000 \\
22800 \\
35200 \\
55500\end{array}$ & 0.35 & $\begin{array}{l}1.22 \\
1.24 \\
1.29 \\
1.34 \\
1.40\end{array}$ & $\begin{array}{l}1075 \\
1235 \\
1455 \\
1820 \\
2140\end{array}$ & $\begin{array}{r}700 \\
786 \\
910 \\
1040 \\
1160\end{array}$ \\
\hline
\end{tabular}




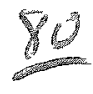

Table 5 (Continued)

\begin{tabular}{|c|c|c|c|c|c|c|c|c|c|c|c|}
\hline Impe & Her & \multirow{2}{*}{$\begin{array}{c}\text { Inter- } \\
\text { facial } \\
\text { Area, a, } \\
\text { from } \\
\text { light } t^{b} \\
\mathrm{~cm}^{-1}\end{array}$} & \multirow{2}{*}{$\begin{array}{c}\text { Set- } \\
\text { ting } \\
\text { Time } \\
\text { t } \\
\text { min }\end{array}$} & \multirow[b]{2}{*}{$\begin{array}{l}\text { Area } \\
\text { Group } \\
\text { Da }\end{array}$} & \multirow{2}{*}{$\begin{array}{c}\begin{array}{c}\text { Weber } \\
\text { No. }\end{array} \\
\frac{\mathrm{D}^{3} \mathrm{~N}^{2} \rho_{\mathrm{F}}}{\sigma_{\mathrm{i}}}\end{array}$} & \multirow{2}{*}{$\begin{array}{c}\text { Impeller- } \\
\text { Tank } \\
\text { Ratio } \\
\text { D/T }\end{array}$} & \multirow{2}{*}{$\begin{array}{c}\mathrm{D} / \mathrm{T} \\
\text { Depend- } \\
\text { enced } \\
k\end{array}$} & \multicolumn{2}{|r|}{$\mathrm{Da}^{e, f, h}$} & \multicolumn{2}{|l|}{$\mathrm{Da}^{e, \mathfrak{f}, \mathfrak{j}}$} \\
\hline $\begin{array}{c}\text { Diam } \\
\text { D } \\
f t\end{array}$ & $\begin{array}{c}\operatorname{Rev} \\
N \\
\sec ^{-1}\end{array}$ & & & & & & & $\left(\frac{\mathrm{D}}{\mathrm{T}}\right)^{\mathrm{k}}\left(\frac{\nu_{\mathrm{D}}}{v_{\mathrm{F}}}\right)^{1 / 5}$ & $\exp \left(3.6 \frac{\Delta \rho}{\rho_{\mathrm{F}}}\right)\left(\frac{\mathrm{t}}{\mathrm{t}_{0}}\right)^{1 / 6} \phi$ & $\left(\frac{D}{T}\right)\left(\frac{\nu_{D}}{\nu_{F}}\right)^{1 / 5} \exp$ & $\left(3.6 \frac{\Delta \rho}{\rho_{F}}\right) \phi$ \\
\hline \multicolumn{2}{|c|}{ Run 1128} & Isobutanol & in Water & - Symb & $01 \mathrm{M} / \mathrm{Co}$ & ntinued) & & & & & \\
\hline 0.50 & $\begin{array}{l}2.0 \\
2.7 \\
3.2 \\
4.8 \\
5.4\end{array}$ & $\begin{array}{r}71.0 \\
88.4 \\
99.1 \\
124.6 \\
133.0\end{array}$ & $\begin{array}{l}0.59 \\
0.59 \\
0.57 \\
0.53 \\
0.51\end{array}$ & $\begin{array}{l}1085 \\
1350 \\
1515 \\
1905 \\
2010\end{array}$ & $\begin{array}{r}6650 \\
12100 \\
17000 \\
38200 \\
48500\end{array}$ & 0.526 & $\begin{array}{l}1.16 \\
1.22 \\
1.26 \\
1.35 \\
1.38\end{array}$ & & $\begin{array}{r}900 \\
1160 \\
1340 \\
1785 \\
1950\end{array}$ & $\begin{array}{r}668 \\
827 \\
928 \\
1165 \\
1250\end{array}$ & \\
\hline 0.667 & $\begin{array}{l}1.37 \\
2.1 \\
2.9 \\
3.2 \\
3.6\end{array}$ & $\begin{array}{r}76.2 \\
102.7 \\
125.3 \\
140.0 \\
146.9\end{array}$ & $\begin{array}{l}0.64 \\
0.57 \\
0.54 \\
0.52 \\
0.50\end{array}$ & $\begin{array}{l}1550 \\
2070 \\
2550 \\
2840 \\
2990\end{array}$ & $\begin{array}{r}7400 \\
17400 \\
33000 \\
40000 \\
51000\end{array}$ & 0.705 & $\begin{array}{l}1.17 \\
1.26 \\
1.33 \\
1.37 \\
1.39\end{array}$ & & $\begin{array}{r}918 \\
1260 \\
1590 \\
1800 \\
1910\end{array}$ & $\begin{array}{r}708 \\
952 \\
1165 \\
1310 \\
1370\end{array}$ & \\
\hline
\end{tabular}

a Data are for $50 \%$ o/W dispersions at $25 \mathrm{C}$.

b Supporting data given in Table 8 .

c Settling time taken from instant stirrer is stopped to first appearance of clear inter face. When used in correlations the value given is divided by 2 to express as equivalent value in 6 -inch vessel.

d A function of Weber No. shown in Figure 18.

e Values of correlating physical parameters given in Table 10.

I $\phi$ is scale-up factor obtained from Figure $20 . \phi=1.46$ for $12^{\text {" }}$ tank.

g A kerosene obtained from Central Solvents and Chemicals Co., Chicago, I11. Solvent was prewashed with caustic and water and then distilled.

h Data used in correlation shown in Figure 21.

j Data used in correlation shown in Figure 22. 


\section{1}

Table 6. Area and Settling Time Data Obtained in 18" Tanka*

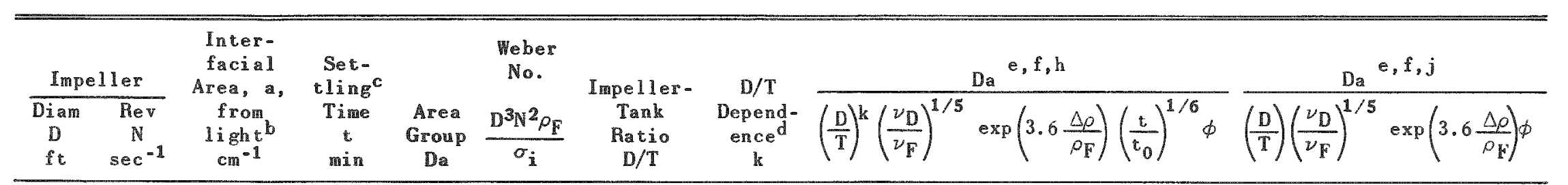

Run 1123 Hexone (Methyl Isobutyl Retone) in Water - Symbol $\mathrm{K}$

$\begin{array}{rrrrrrrrr}0.333 & 10.4 & 40.6 & 0.50 & 414 & 10650 & 0.23 & 1.22 & 850 \\ & 15.5 & 51.8 & 0.50 & 528 & 23650 & & 1.30 & 1105 \\ & 20.6 & 57.3 & 0.50 & 586 & 41800 & & 1.36 & 1470 \\ 0.50 & 4.6 & 50.9 & 0.50 & 777 & 7050 & 0.34 & 1.17 & 933 \\ & 5.25 & 53.8 & 0.51 & 821 & 9170 & & 1.19 & 1005 \\ & 6.65 & 57.9 & 0.48 & 882 & 14700 & & 1.24 & 1145 \\ & 7.2 & 61.7 & 0.48 & 942 & 17250 & & 1.26 & 1245 \\ 0.667 & 2.6 & 46.2 & 0.44 & 936 & 5300 & 0.46 & 1.14 & 773 \\ & 3.1 & 50.9 & 0.44 & 1040 & 7600 & & 1.17 & 874 \\ 0.75 & 3.24 & 51.5 & 0.46 & 1045 & 8300 & & 1.185 & 896 \\ & 2.07 & 41.2 & 0.40 & 924 & 4820 & 0.51 & 1.13 & 673 \\ & 2.43 & 44.1 & 0.40 & 1005 & 6650 & & 1.16 & 741 \\ 1.0 & 2.57 & 47.1 & 0.40 & 1075 & 7450 & & 1.17 & 801 \\ & 1.22 & 40.0 & 0.37 & 1220 & 3960 & 0.685 & 1.11 & 632\end{array}$

Run 113 Asmscos in Water - Syrbol $\mathrm{C}$

\begin{tabular}{|c|c|c|c|c|c|c|c|c|c|}
\hline 0.333 & 9.5 & 75.9 & 5.2 & 774 & 2140 & 0.23 & 1.05 & 645 & 636 \\
\hline 0.50 & $\begin{array}{l}3.4 \\
5.35 \\
6.8 \\
7.2\end{array}$ & $\begin{array}{l}73.6 \\
78.1 \\
85.1 \\
85.1\end{array}$ & $\begin{array}{l}4.3 \\
4.4 \\
4.8 \\
4.8\end{array}$ & $\begin{array}{l}1125 \\
1190 \\
1300 \\
1300\end{array}$ & $\begin{array}{r}925 \\
2300 \\
3700 \\
4150\end{array}$ & 0.34 & $\begin{array}{l}0.98 \\
1.06 \\
1.11 \\
1.12\end{array}$ & $\begin{array}{l}586 \\
672 \\
765 \\
778\end{array}$ & $\begin{array}{l}624 \\
663 \\
723 \\
723\end{array}$ \\
\hline 0.667 & $\begin{array}{l}2.7 \\
3.05 \\
3.35\end{array}$ & $\begin{array}{l}69.8 \\
77.4 \\
78.2\end{array}$ & $\begin{array}{l}5.1 \\
4.8 \\
4.8\end{array}$ & $\begin{array}{l}1415 \\
1570 \\
1585\end{array}$ & $\begin{array}{l}1390 \\
1770 \\
2130\end{array}$ & 0.46 & $\begin{array}{l}1.02 \\
1.04 \\
1.05\end{array}$ & $\begin{array}{l}551 \\
627 \\
636\end{array}$ & $\begin{array}{l}586 \\
645 \\
654\end{array}$ \\
\hline 0.75 & $\begin{array}{l}2.6 \\
2.6\end{array}$ & $\begin{array}{l}69.4 \\
72.0\end{array}$ & $\begin{array}{l}5.9 \\
6.0\end{array}$ & $\begin{array}{l}1590 \\
1645\end{array}$ & $\begin{array}{l}1900 \\
1900\end{array}$ & 0.51 & $\begin{array}{l}1.04 \\
1.04\end{array}$ & $\begin{array}{l}556 \\
569\end{array}$ & $\begin{array}{l}590 \\
608\end{array}$ \\
\hline 1.0 & 1.17 & 52.0 & 2.1 & 1585 & 875 & 0.685 & 0.975 & 474 & 438 \\
\hline
\end{tabular}

Lower case superscripts (except $k$ ) refer to footnotes on page 83. 
Table 6 (Continued) $^{a}$

\begin{tabular}{|c|c|c|c|c|c|c|c|c|c|c|}
\hline Impe & ller & $\begin{array}{c}\text { Inter- } \\
\text { facial } \\
\text { Area, }\end{array}$ & $\begin{array}{l}\text { Set- } \\
t \operatorname{ling}{ }^{c}\end{array}$ & & $\begin{array}{c}\text { Weber } \\
\text { No. }\end{array}$ & Impeller- & $\mathrm{D} / \mathrm{T}$ & & $\mathrm{Da} e, f, h$ & $\mathrm{Da}^{e, f, j}$ \\
\hline $\begin{array}{c}\text { Diam } \\
\text { D } \\
\text { ft }\end{array}$ & $\begin{array}{c}\operatorname{Rev} \\
N \\
\sec ^{-1}\end{array}$ & $\begin{array}{l}\text { from } \\
\operatorname{ligh}^{b} \\
\mathrm{~cm}^{-1}\end{array}$ & $\begin{array}{l}\text { Time } \\
t \\
\text { min }\end{array}$ & $\begin{array}{l}\text { Area } \\
\text { Group } \\
\text { Da }\end{array}$ & $\frac{\mathrm{D}^{3} \mathrm{~N}^{2} \rho_{\mathrm{F}}}{\sigma_{\mathrm{i}}}$ & $\begin{array}{c}\text { Tank } \\
\text { Ratio } \\
D / T\end{array}$ & $\begin{array}{l}\text { Depend- } \\
\text { ence } \\
\quad k\end{array}$ & $\left(\frac{D}{T}\right)^{k}\left(\frac{\nu_{D}}{\nu_{F}}\right)^{1 / 5}$ & $\exp \left(3.6 \frac{\Delta \rho}{\rho_{\mathrm{F}}}\right)\left(\frac{t}{t_{0}}\right)^{1 / 6} \phi$ & $\left(\frac{\mathrm{D}}{\mathrm{T}}\right)\left(\frac{\nu_{\mathrm{D}}}{\nu_{\mathrm{F}}}\right)^{1 / 5} \exp \left(3.6 \frac{\Delta \rho}{\rho_{\mathrm{F}}}\right) \phi$ \\
\hline Run 11 & & Xylene in & Water - $S$ & ymbol D & & & & & & \\
\hline 0.333 & $\begin{array}{r}8.4 \\
10.4 \\
15.7\end{array}$ & $\begin{array}{l}44.3 \\
46.6 \\
46.6\end{array}$ & 4.2 & $\begin{array}{l}452 \\
576 \\
576\end{array}$ & $\begin{array}{l}1940 \\
2980 \\
6780\end{array}$ & 0.23 & $\begin{array}{l}1.05 \\
1.08 \\
1.16\end{array}$ & & $\begin{array}{l}609 \\
663 \\
768\end{array}$ & $\begin{array}{l}576 \\
604 \\
604\end{array}$ \\
\hline 0.50 & $\begin{array}{l}4.7 \\
5.33 \\
6.75\end{array}$ & $\begin{array}{l}44.2 \\
45.7 \\
45.7\end{array}$ & 3.85 & $\begin{array}{l}672 \\
697 \\
697\end{array}$ & $\begin{array}{l}2050 \\
2630 \\
4220\end{array}$ & 0.347 & $\begin{array}{l}1.05 \\
1.07 \\
1.12\end{array}$ & & $\begin{array}{l}592 \\
624 \\
663\end{array}$ & $\begin{array}{l}567 \\
585 \\
585\end{array}$ \\
\hline 0.667 & $\begin{array}{l}2.04 \\
2.83 \\
3.07\end{array}$ & $\begin{array}{l}40.4 \\
44.6 \\
44.6\end{array}$ & 3.7 & $\begin{array}{l}818 \\
906 \\
906\end{array}$ & $\begin{array}{r}915 \\
1760 \\
2070\end{array}$ & 0.462 & $\begin{array}{l}0.98 \\
1.04 \\
1.05\end{array}$ & & $\begin{array}{l}522 \\
573 \\
587\end{array}$ & $\begin{array}{l}517 \\
572 \\
572\end{array}$ \\
\hline 0.750 & $\begin{array}{l}2.0 \\
2.4 \\
2.47\end{array}$ & $\begin{array}{l}42.0 \\
45.7 \\
45.7\end{array}$ & 3.7 & $\begin{array}{r}960 \\
1045 \\
1045\end{array}$ & $\begin{array}{l}1250 \\
1795 \\
1910\end{array}$ & 0.52 & $\begin{array}{l}1.00 \\
1.04 \\
1.05\end{array}$ & & $\begin{array}{l}535 \\
599 \\
602\end{array}$ & $\begin{array}{l}539 \\
587 \\
587\end{array}$ \\
\hline 1.0 & $\begin{array}{l}1.17 \\
1.20 \\
1.20\end{array}$ & $\begin{array}{l}36.6 \\
38.9 \\
38.9\end{array}$ & 3.3 & $\begin{array}{l}1115 \\
1190 \\
1190\end{array}$ & $\begin{array}{l}1015 \\
1065 \\
1065\end{array}$ & 0.693 & $\begin{array}{l}0.99 \\
0.99 \\
0.99\end{array}$ & & $\begin{array}{l}466 \\
494 \\
494\end{array}$ & $\begin{array}{l}471 \\
498 \\
498\end{array}$ \\
\hline Run 11 & 30 & Isobutanol & in Water & - Symbc & ol M & & & & & \\
\hline 0.333 & $\begin{array}{r}8.4 \\
10.4 \\
15.7 \\
20.6\end{array}$ & $\begin{array}{l}83.2 \\
93.3 \\
124 \\
142\end{array}$ & $\begin{array}{l}1.19 \\
1.17 \\
1.05 \\
1.01\end{array}$ & $\begin{array}{r}850 \\
951 \\
1270 \\
1445\end{array}$ & $\begin{array}{r}34800 \\
55500 \\
121000 \\
209000\end{array}$ & 0.23 & $\begin{array}{l}1.34 \\
1.40 \\
1.49 \\
1.55\end{array}$ & & $\begin{array}{l}1590 \\
1940 \\
2950 \\
3660\end{array}$ & $\begin{array}{r}792 \\
887 \\
1180 \\
1345\end{array}$ \\
\hline 0.500 & $\begin{array}{l}3.2 \\
4.8 \\
5.4 \\
6.75 \\
7.05\end{array}$ & $\begin{array}{l}86.0 \\
108 \\
113 \\
130 \\
130\end{array}$ & $\begin{array}{l}1.20 \\
1.20 \\
1.15 \\
1.10 \\
1.07\end{array}$ & $\begin{array}{l}1310 \\
1645 \\
1730 \\
1980 \\
1980\end{array}$ & $\begin{array}{l}17000 \\
38200 \\
48500 \\
75500 \\
82500\end{array}$ & 0.347 & $\begin{array}{l}1.26 \\
1.35 \\
1.38 \\
1.43 \\
1.45\end{array}$ & & $\begin{array}{l}1310 \\
1800 \\
1950 \\
2360 \\
2410\end{array}$ & $\begin{array}{r}814 \\
1015 \\
1070 \\
1225 \\
1225\end{array}$ \\
\hline
\end{tabular}




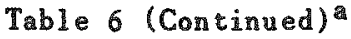

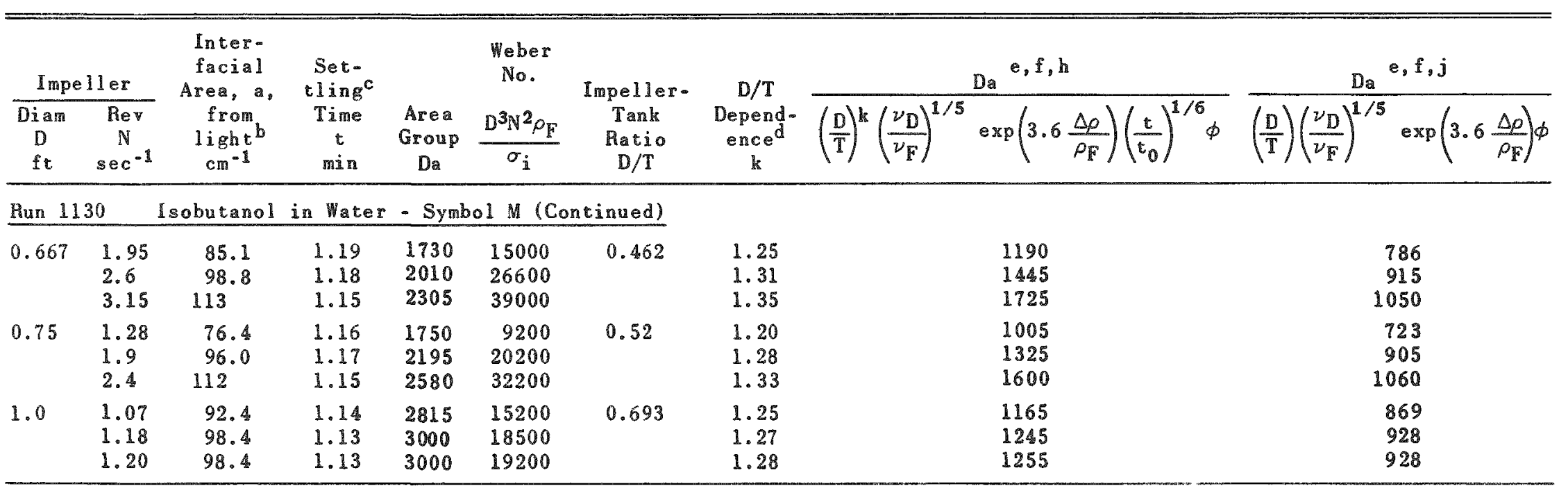

- Data are for $50 \%$ o/w dispersions at $25 \mathrm{C}$.

b Supporting data given in Table 9.

c Settling time taken fron instant stirrer is stopped to first appearance of clear interface. When used in correlations the value given is divided by 3 to express as an equivalent value in 6 -inch vessel.

d A function of the Weber Number shown in Figure 18.

e Value of correlating physical parameters given in Table 10.

$f \phi$ is scale-up factor obtained from Figure $20 . \phi=2.15$ for $18^{\prime \prime}$ tank.

g A kerosene obtained from Central Solvents \& Chemical Co., Chicago, I11. Solvent was prewashed with caustic and water and then distilled.

h Data used in correlation shown in Figure 21.

j Data used in correlation shown in Figure 22. 
APPENDIX II

LIGHT TRANSMITTANCE DATA 
Table 7. Light Transmittance Data Obtained in $6^{\prime \prime}$ Tank ${ }^{*}$

\begin{tabular}{|c|c|c|c|c|c|c|c|c|c|c|}
\hline \multicolumn{2}{|c|}{ Impel ler } & \multirow{2}{*}{\multicolumn{4}{|c|}{ Probe }} & \multirow[b]{3}{*}{$\mathbb{I}_{0}^{c}$} & \multirow[b]{3}{*}{$\mathbb{I}^{d}$} & \multirow[b]{3}{*}{$\ln \frac{I_{0}}{I}$} & \multirow{2}{*}{\multicolumn{2}{|c|}{$\begin{array}{c}\text { Interfacial } \\
\text { Area. }\end{array}$}} \\
\hline$\overline{\mathrm{Di} \text { an }}$ & Rev & & & & & & & & & \\
\hline $\begin{array}{l}D \\
f t\end{array}$ & $\sec ^{-1}$ & $\begin{array}{l}\text { Assem- } \\
\text { blyb }\end{array}$ & $\begin{array}{c}\text { Dark } \\
\text { Current }\end{array}$ & $\begin{array}{c}\text { Zero } \\
\text { Reading }\end{array}$ & $\begin{array}{c}\text { Measured } \\
\text { Current }\end{array}$ & & & & & $\mathrm{cm} / \mathrm{sq} \mathrm{cm}$ \\
\hline \multicolumn{2}{|c|}{ Run 922} & \multicolumn{4}{|c|}{ Cyclohexane in Water } & & & & & \\
\hline 0.167 & $\begin{array}{l}8.98 \\
13.7 \\
17.9\end{array}$ & $\mathrm{~B}$ & $\begin{array}{l}8.948 \\
8.952 \\
8.952\end{array}$ & 0.185 & $\begin{array}{l}8.651 \\
8.772 \\
8.817\end{array}$ & $\begin{array}{l}8.763 \\
8.767 \\
8.767\end{array}$ & $\begin{array}{l}0.297 \\
0.180 \\
0.135\end{array}$ & $\begin{array}{l}3.38 \\
3.89 \\
4.17\end{array}$ & & $\begin{array}{l}49.3 \\
61.8 \\
68.7\end{array}$ \\
\hline 0.25 & $\begin{array}{l}3.95 \\
4.50 \\
5.67 \\
7.30\end{array}$ & & 8.953 & 0.237 & $\begin{array}{l}8.463 \\
8.562 \\
8.674 \\
8.749\end{array}$ & 8.716 & $\begin{array}{l}0.490 \\
0.391 \\
0.279 \\
0.204\end{array}$ & $\begin{array}{l}2.88 \\
3.11 \\
3.42 \\
3.72\end{array}$ & & $\begin{array}{l}41.2 \\
44.6 \\
51.0 \\
57.7\end{array}$ \\
\hline 0.333 & $\begin{array}{l}2.73 \\
3.95 \\
4.50 \\
5.67\end{array}$ & & 8.952 & 0.037 & $\begin{array}{l}8.503 \\
8.696 \\
8.727 \\
8.782\end{array}$ & 8.915 & $\begin{array}{l}0.449 \\
0.256 \\
0.225 \\
0.170\end{array}$ & $\begin{array}{l}2.99 \\
3.55 \\
3.68 \\
3.96\end{array}$ & & $\begin{array}{l}43.0 \\
53.5 \\
56.5 \\
64.0\end{array}$ \\
\hline \multicolumn{2}{|c|}{ Run 628} & sco (tre & ated) in & Water & & & & & & \\
\hline 0.167 & $\begin{array}{r}9.04 \\
13.75 \\
18.08\end{array}$ & $\mathrm{~B}$ & $\begin{array}{l}8.827 \\
8.827 \\
8.832\end{array}$ & 0.128 & $\begin{array}{l}8.513 \\
8.702 \\
8.759\end{array}$ & $\begin{array}{l}8.699 \\
8.699 \\
8.704\end{array}$ & $\begin{array}{l}0.314 \\
0.125 \\
0.073\end{array}$ & $\begin{array}{l}3.32 \\
4.25 \\
4.77\end{array}$ & & $\begin{array}{l}42.6 \\
61.8 \\
76.0\end{array}$ \\
\hline 0.25 & $\begin{array}{l}4.38 \\
5.66 \\
7.27\end{array}$ & & $\begin{array}{l}8.854 \\
8.852 \\
8.854\end{array}$ & 0.278 & $\begin{array}{l}8.424 \\
8.630 \\
8.727\end{array}$ & $\begin{array}{l}8.576 \\
8.574 \\
8.576\end{array}$ & $\begin{array}{l}0.436 \\
0.222 \\
0.127\end{array}$ & $\begin{array}{l}2.99 \\
3.65 \\
4.20\end{array}$ & & $\begin{array}{l}37.5 \\
48.6 \\
60.5\end{array}$ \\
\hline 0.333 & $\begin{array}{l}2.68 \\
3.89 \\
4.38\end{array}$ & & $\begin{array}{l}8.843 \\
8.844 \\
8.843\end{array}$ & 0.247 & $\begin{array}{l}8.185 \\
8.573 \\
8.623\end{array}$ & $\begin{array}{l}8.596 \\
8.597 \\
8.596\end{array}$ & $\begin{array}{l}0.658 \\
0.271 \\
0.220\end{array}$ & $\begin{array}{l}2.57 \\
3.46 \\
3.67\end{array}$ & & $\begin{array}{l}31.1 \\
45.3 \\
48.0\end{array}$ \\
\hline Run 23 & & lene in & Water & & & & & & & \\
\hline 0.167 & $\begin{array}{l}8.48 \\
13.5 \\
17.85\end{array}$ & $\mathrm{D}$ & $\begin{array}{l}9.325 \\
9.323 \\
9.323\end{array}$ & 0.365 & $\begin{array}{l}9.045 \\
9.167 \\
9.203\end{array}$ & $\begin{array}{l}8.960 \\
8.958 \\
8.958\end{array}$ & $\begin{array}{l}0.280 \\
0.156 \\
0.120\end{array}$ & $\begin{array}{l}3.47 \\
4.05 \\
4.31\end{array}$ & & $\begin{array}{l}31.7 \\
40.2 \\
44.8\end{array}$ \\
\hline 0.25 & $\begin{array}{l}3.62 \\
4.18 \\
5.38 \\
5.38 \\
7.05 \\
8.48\end{array}$ & & $\begin{array}{l}9.284 \\
9.285 \\
9.281 \\
9.281 \\
9.301 \\
9.318\end{array}$ & 0.132 & $\begin{array}{l}8.830 \\
8.949 \\
9.063 \\
9.021 \\
9.125 \\
9.160\end{array}$ & $\begin{array}{l}9.152 \\
9.153 \\
9.149 \\
9.261 \\
9.281 \\
9.298\end{array}$ & $\begin{array}{l}0.454 \\
0.336 \\
0.218 \\
0.261 \\
0.176 \\
0.158\end{array}$ & $\begin{array}{l}3.00 \\
3.30 \\
3.74 \\
3.56 \\
3.97 \\
4.07\end{array}$ & & $\begin{array}{l}26.2 \\
29.4 \\
35.7 \\
32.9 \\
39.4 \\
40.7\end{array}$ \\
\hline 0.333 & $\begin{array}{l}3.62 \\
4.18 \\
5.38\end{array}$ & & $\begin{array}{l}9.337 \\
9.334 \\
9.337\end{array}$ & 0.179 & $\begin{array}{l}9.085 \\
9.121 \\
9.183\end{array}$ & $\begin{array}{l}9.158 \\
9.155 \\
9.158\end{array}$ & $\begin{array}{l}0.252 \\
0.213 \\
0.154\end{array}$ & $\begin{array}{l}3.59 \\
3.76 \\
4.09\end{array}$ & & $\begin{array}{l}32.3 \\
35.8 \\
41.2\end{array}$ \\
\hline
\end{tabular}

- Lower case superscripts refer to footnotes on page 88. 
Table 7 (Continued $)^{a}$

\begin{tabular}{|c|c|c|c|c|c|c|c|c|c|c|}
\hline \multicolumn{2}{|c|}{ Impeller } & \multirow{2}{*}{\multicolumn{4}{|c|}{ Probe }} & \multirow[b]{3}{*}{$\mathbb{I}_{0}^{c}$} & \multirow[b]{3}{*}{$I^{d}$} & \multirow[b]{3}{*}{$\ln \frac{I_{0}}{I}$} & \multirow{2}{*}{\multicolumn{2}{|c|}{$\begin{array}{c}\text { Interfacial } \\
\text { Area }\end{array}$}} \\
\hline Di am & $\operatorname{Rev}$ & & & & & & & & & \\
\hline $\begin{array}{c}D \\
f t\end{array}$ & $\sec ^{-1}$ & $\begin{array}{c}\text { Assem- } \\
\text { bly }\end{array}$ & $\begin{array}{c}\text { Dark } \\
\text { Current }\end{array}$ & $\begin{array}{c}\text { Zero } \\
\text { Reading }\end{array}$ & $\begin{array}{c}\text { Measured } \\
\text { Current }\end{array}$ & & & & & $\mathrm{cm} / \mathrm{sq} \mathrm{cm}$ \\
\hline Run 29 & & $3 \%$ White & Oil-Xylene & in Water & & & & & & \\
\hline 0.167 & $\begin{array}{r}8.8 \\
13.5 \\
17.6\end{array}$ & $\mathrm{D}$ & $\begin{array}{l}9.352 \\
9.380 \\
9.378\end{array}$ & 0.445 & $\begin{array}{l}9.122 \\
9.240 \\
9.273\end{array}$ & $\begin{array}{l}8.907 \\
8.935 \\
8.933\end{array}$ & $\begin{array}{l}0.230 \\
0.140 \\
0.105\end{array}$ & $\begin{array}{l}3.45 \\
4.15 \\
4.44\end{array}$ & & $\begin{array}{l}32.6 \\
43.5 \\
49.4\end{array}$ \\
\hline 0.25 & $\begin{array}{l}3.66 \\
4.24 \\
5.45 \\
7.0 \\
8.8\end{array}$ & & $\begin{array}{l}9.350 \\
9.352 \\
9.351 \\
9.350 \\
9.352\end{array}$ & 0.472 & $\begin{array}{l}8.913 \\
9.027 \\
9.133 \\
9.198 \\
9.229\end{array}$ & $\begin{array}{l}8.878 \\
8.880 \\
8.879 \\
8.878 \\
8.880\end{array}$ & $\begin{array}{l}0.437 \\
0.325 \\
0.218 \\
0.152 \\
0.123\end{array}$ & $\begin{array}{l}3.01 \\
3.31 \\
3.70 \\
4.07 \\
4.29\end{array}$ & & $\begin{array}{l}27.1 \\
30.5 \\
36.0 \\
42.0 \\
46.3\end{array}$ \\
\hline 0.333 & $\begin{array}{l}2.45 \\
3.66 \\
4.24 \\
5.45\end{array}$ & & $\begin{array}{l}9.340 \\
9.338 \\
9.343 \\
9.342\end{array}$ & 0.380 & $\begin{array}{l}8.815 \\
9.095 \\
9.140 \\
9.194\end{array}$ & $\begin{array}{l}8.960 \\
8.958 \\
8.963 \\
8.962\end{array}$ & $\begin{array}{l}0.525 \\
0.243 \\
0.203 \\
0.148\end{array}$ & $\begin{array}{l}2.84 \\
3.60 \\
3.79 \\
4.10\end{array}$ & & $\begin{array}{l}25.2 \\
34.7 \\
37.5 \\
42.6\end{array}$ \\
\hline Run 214 & & $8 \%$ White & Oil-Xylene & in Water & & & & & & \\
\hline 0.167 & $\begin{array}{r}8.8 \\
13.5 \\
17.6\end{array}$ & $\mathrm{D}$ & $\begin{array}{l}9.332 \\
9.331 \\
9.331\end{array}$ & 0.150 & $\begin{array}{l}9.115 \\
9.205 \\
9.234\end{array}$ & $\begin{array}{l}9.182 \\
9.181 \\
9.181\end{array}$ & $\begin{array}{l}0.217 \\
0.126 \\
0.089\end{array}$ & $\begin{array}{l}3.74 \\
4.29 \\
4.65\end{array}$ & & $\begin{array}{l}37.2 \\
46.8 \\
54.5\end{array}$ \\
\hline 0.25 & $\begin{array}{l}3.66 \\
4.24 \\
5.45 \\
7.0 \\
8.8\end{array}$ & & $\begin{array}{l}9.352 \\
9.349 \\
9.343 \\
9.339 \\
9.338\end{array}$ & 0.131 & $\begin{array}{l}9.00 \\
9.077 \\
9.152 \\
9.204 \\
9.230\end{array}$ & $\begin{array}{l}9.221 \\
9.218 \\
9.212 \\
9.208 \\
9.207\end{array}$ & $\begin{array}{l}0.352 \\
0.272 \\
0.191 \\
0.135 \\
0.108\end{array}$ & $\begin{array}{l}3.26 \\
3.52 \\
3.88 \\
4.23 \\
4.44\end{array}$ & & $\begin{array}{l}30.4 \\
33.7 \\
39.2 \\
45.4 \\
49.8\end{array}$ \\
\hline 0.333 & $\begin{array}{l}2.45 \\
3.66 \\
4.24 \\
5.45\end{array}$ & & $\begin{array}{l}9.337 \\
9.333 \\
9.333 \\
9.331\end{array}$ & 0.055 & $\begin{array}{l}8.925 \\
9.133 \\
9.165 \\
9.203\end{array}$ & $\begin{array}{l}9.282 \\
9.278 \\
9.278 \\
9.276\end{array}$ & $\begin{array}{l}0.412 \\
0.200 \\
0.170 \\
0.128\end{array}$ & $\begin{array}{l}3.11 \\
3.84 \\
3.99 \\
4.28\end{array}$ & & $\begin{array}{l}28.4 \\
38.6 \\
41.2 \\
46.8\end{array}$ \\
\hline Run 224 & & $1 \%$ White & Oil-Xylene & in Water & & & & & & \\
\hline 0.25 & $\begin{array}{l}3.89 \\
4.38 \\
5.66 \\
7.27\end{array}$ & $\mathrm{D}$ & $\begin{array}{l}9.409 \\
9.403 \\
9.411 \\
9.408\end{array}$ & 0.358 & $\begin{array}{l}9.281 \\
9.313 \\
9.349 \\
9.364\end{array}$ & $\begin{array}{l}9.051 \\
9.045 \\
9.053 \\
9.050\end{array}$ & $\begin{array}{l}0.128 \\
0.090 \\
0.062 \\
0.044\end{array}$ & $\begin{array}{l}4.25 \\
4.60 \\
4.99 \\
5.32\end{array}$ & & $\begin{array}{l}47.5 \\
55.2 \\
66.3 \\
77.0\end{array}$ \\
\hline 0.333 & $\begin{array}{l}2.68 \\
3.89 \\
4.38\end{array}$ & & $\begin{array}{l}9.411 \\
9.413 \\
9.414\end{array}$ & 0.450 & $\begin{array}{l}9.274 \\
9.346 \\
9.365\end{array}$ & $\begin{array}{l}8.955 \\
8.957 \\
8.958\end{array}$ & $\begin{array}{l}0.137 \\
0.067 \\
0.049\end{array}$ & $\begin{array}{l}4.18 \\
4.90 \\
5.20\end{array}$ & & $\begin{array}{l}45.7 \\
63.1 \\
72.7\end{array}$ \\
\hline
\end{tabular}


Table 7 (Concinued) ${ }^{a}$

\begin{tabular}{|c|c|c|c|c|c|c|c|c|c|c|}
\hline \multicolumn{2}{|c|}{ Impe 11 ex } & \multirow{2}{*}{\multicolumn{4}{|c|}{ Prabe }} & \multirow[b]{3}{*}{$\mathbb{I}_{0}^{c}$} & \multirow[b]{3}{*}{$I^{d}$} & \multirow[b]{3}{*}{$\ln \frac{I_{0}}{I}$} & \multirow{2}{*}{\multicolumn{2}{|c|}{$\begin{array}{c}\text { Interfacial } \\
\text { Area, }\end{array}$}} \\
\hline Diam & Rev & & & & & & & & & \\
\hline $\mathrm{D}$ & $\sec ^{-1}$ & $\begin{array}{l}\text { Assem- } \\
\text { bly b }\end{array}$ & $\begin{array}{c}\text { Dark } \\
\text { Current }\end{array}$ & $\begin{array}{c}\text { Zero } \\
\text { Reading }\end{array}$ & $\begin{array}{c}\text { Measured } \\
\text { Current }\end{array}$ & & & & $\mathrm{cu}$ & $\mathrm{cm} / \mathrm{sq} \mathrm{cm}$ \\
\hline Run 314 & \multicolumn{2}{|c|}{ Benzene in } & Water & & & & & & & \\
\hline 0.167 & $\begin{array}{l}9.04 \\
13.75 \\
18.1\end{array}$ & $\mathrm{D}$ & $\begin{array}{l}9.382 \\
9.380 \\
9.380\end{array}$ & 0.21 & $\begin{array}{l}8.86 \\
9.10 \\
9.19\end{array}$ & $\begin{array}{l}9.172 \\
9.17 \\
9.17\end{array}$ & $\begin{array}{l}0.522 \\
0.280 \\
0.190\end{array}$ & $\begin{array}{l}2.86 \\
3.48 \\
3.87\end{array}$ & & $\begin{array}{l}24.5 \\
31.9 \\
37.1\end{array}$ \\
\hline 0.25 & $\begin{array}{l}3.89 \\
4.38 \\
5.66 \\
7.27\end{array}$ & & $\begin{array}{l}9.375 \\
9.380 \\
9.380 \\
9.380\end{array}$ & 0.21 & $\begin{array}{l}8.65 \\
8.80 \\
8.99 \\
9.11\end{array}$ & $\begin{array}{l}9.165 \\
9.17 \\
9.17 \\
9.17\end{array}$ & $\begin{array}{l}0.725 \\
0.58 \\
0.39 \\
0.27\end{array}$ & $\begin{array}{l}2.53 \\
2.75 \\
3.15 \\
3.52\end{array}$ & & $\begin{array}{l}21.2 \\
23.3 \\
27.6 \\
32.5\end{array}$ \\
\hline 0.333 & $\begin{array}{l}3.89 \\
4.38 \\
5.66\end{array}$ & & $\begin{array}{l}9.380 \\
9.380 \\
9.380\end{array}$ & 0.21 & $\begin{array}{l}9.027 \\
9.107 \\
9.197\end{array}$ & $\begin{array}{l}9.17 \\
9.17 \\
9.17\end{array}$ & $\begin{array}{l}0.353 \\
0.273 \\
0.183\end{array}$ & $\begin{array}{l}3.25 \\
3.51 \\
3.91\end{array}$ & & $\begin{array}{l}28.9 \\
32.4 \\
38.3\end{array}$ \\
\hline Run 216 & He & xone in & Water & & & & & & & \\
\hline 0.167 & $\begin{array}{r}8.8 \\
13.5 \\
17.6\end{array}$ & D & $\begin{array}{l}9.380 \\
9.372 \\
9.375\end{array}$ & 0.33 & $\begin{array}{l}8.13 \\
8.676 \\
8.90\end{array}$ & $\begin{array}{l}9.05 \\
9.042 \\
9.045\end{array}$ & $\begin{array}{l}1.25 \\
0.696 \\
0.475\end{array}$ & $\begin{array}{l}1.98 \\
2.56 \\
2.95\end{array}$ & & $\begin{array}{l}38.9 \\
50.7 \\
60.8\end{array}$ \\
\hline 0.25 & $\begin{array}{l}3.66 \\
4.24 \\
5.45 \\
7.0 \\
8.8\end{array}$ & & $\begin{array}{l}9.37 \\
9.37 \\
9.37 \\
9.372 \\
9.375\end{array}$ & 0.43 & $\begin{array}{l}7.55 \\
8.15 \\
8.53 \\
8.77 \\
9.01\end{array}$ & $\begin{array}{l}8.94 \\
8.94 \\
8.94 \\
8.942 \\
8.945\end{array}$ & $\begin{array}{l}1.82 \\
1.22 \\
0.84 \\
0.602 \\
0.365\end{array}$ & $\begin{array}{l}1.59 \\
1.99 \\
2.36 \\
2.70 \\
3.20\end{array}$ & & $\begin{array}{l}31.2 \\
39.1 \\
46.3 \\
54.0 \\
67.6\end{array}$ \\
\hline 0.333 & 2.45 & & 9.385 & 0.35 & 7.9 & 9.035 & 1.485 & 1.80 & & 35.4 \\
\hline Run 927 & $\mathrm{Ch}$ & lorobenze & ene in Wa & $=x$ & & & & & & \\
\hline 0.25 & $\begin{array}{l}3.95 \\
4.50 \\
5.67 \\
7.30 \\
8.98\end{array}$ & B & $\begin{array}{l}8.971 \\
8.971 \\
8.972 \\
8.972 \\
8.972\end{array}$ & 0.209 & $\begin{array}{l}8.576 \\
8.649 \\
8.743 \\
8.806 \\
8.852\end{array}$ & $\begin{array}{l}8.762 \\
8.762 \\
8.763 \\
8.763 \\
8.763\end{array}$ & $\begin{array}{l}0.395 \\
0.322 \\
0.229 \\
0.166 \\
0.120\end{array}$ & $\begin{array}{l}3.08 \\
3.29 \\
3.63 \\
3.96 \\
4.27\end{array}$ & & $\begin{array}{l}20.7 \\
22.6 \\
25.8 \\
29.5 \\
34.6\end{array}$ \\
\hline Run 730 & I sob & utanol it & n Water & & & & & & & \\
\hline 0.167 & $\begin{array}{c}5.67 \\
7.30 \\
8.98 \\
13.70 \\
17.9\end{array}$ & B & $\begin{array}{l}8.921 \\
8.922 \\
8.920 \\
8.930 \\
8.925\end{array}$ & 0.352 & $\begin{array}{l}8.10 \\
8.41 \\
8.528 \\
8.720 \\
8.785\end{array}$ & $\begin{array}{l}8.569 \\
8.570 \\
8.568 \\
8.578 \\
8.573\end{array}$ & $\begin{array}{l}0.821 \\
0.512 \\
0.392 \\
0.210 \\
0.140\end{array}$ & $\begin{array}{l}2.34 \\
2.82 \\
3.08 \\
3.71 \\
4.11\end{array}$ & & $\begin{array}{r}52.4 \\
65.5 \\
74.0 \\
95.2 \\
111.0\end{array}$ \\
\hline 0.25 & $\begin{array}{l}2.73 \\
3.95 \\
4.50 \\
5.67 \\
7.30\end{array}$ & & $\begin{array}{l}8.925 \\
8.925 \\
8.930 \\
8.930 \\
8.930\end{array}$ & 0.045 & $\begin{array}{l}8.22 \\
8.535 \\
8.601 \\
8.713 \\
8.785\end{array}$ & $\begin{array}{l}8.880 \\
8.880 \\
8.885 \\
8.885 \\
8.885\end{array}$ & $\begin{array}{l}0.705 \\
0.390 \\
0.329 \\
0.217 \\
0.145\end{array}$ & $\begin{array}{l}2.53 \\
3.13 \\
3.30 \\
3.72 \\
4.11\end{array}$ & & $\begin{array}{r}58.1 \\
75.2 \\
80.5 \\
95.2 \\
111.0\end{array}$ \\
\hline
\end{tabular}


Table 7 (Continued $)^{a}$

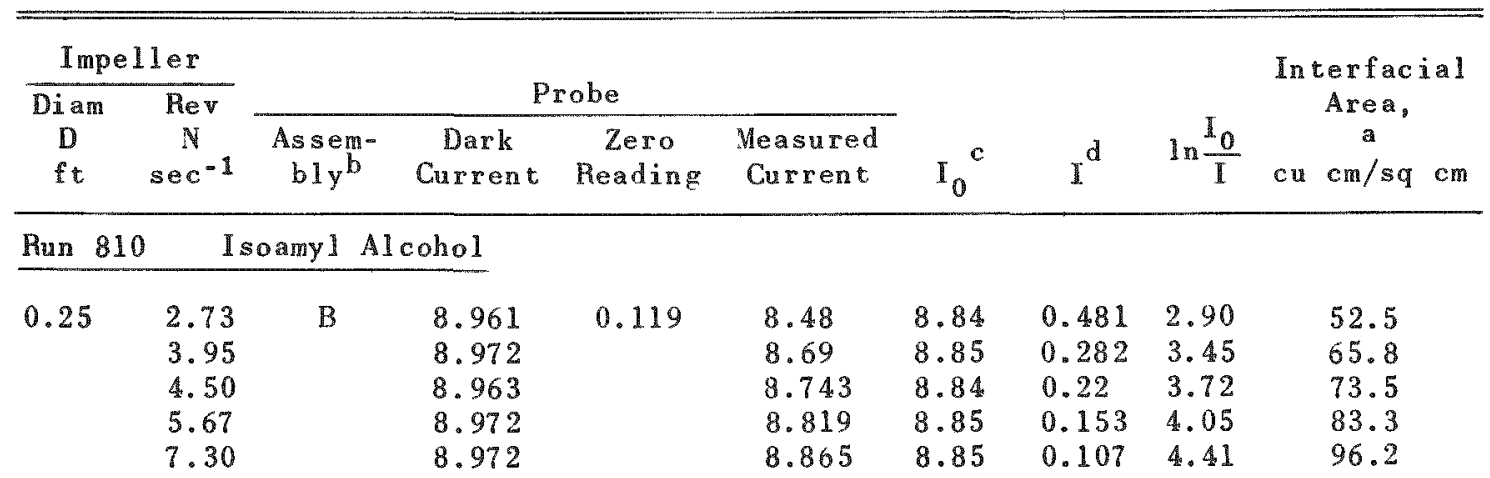

Run 727 11\% Carbon Tetrachloride-Benzene in Water

$\begin{array}{llllllllll}0.25 & 2.73 & \text { B } & 8.898 & 0.185 & 8.40 & 8.713 & 0.498 & 2.86 & 21.5 \\ & 3.95 & & 8.898 & & 8.601 & 8.713 & 0.297 & 3.38 & 26.7 \\ 4.50 & & 8.904 & & 8.658 & 8.719 & 0.246 & 3.56 & 28.7 \\ & 5.67 & & 8.904 & & 8.726 & 8.719 & 0.178 & 3.89 & 32.9\end{array}$

Run $728 \quad 25 \%$ Carbon Tetrachloride-Benzene in Water

$\begin{array}{llllllllll}0.25 & 2.73 & \mathrm{~B} & 8.919 & 0.056 & 8.40 & 8.863 & 0.519 & 2.86 & 22.9 \\ & 3.95 & & 8.924 & & 8.585 & 8.868 & 0.339 & 3.38 & 27.1 \\ 4.50 & & 8.922 & & 8.640 & 8.866 & 0.282 & 3.56 & 29.3 \\ & 5.67 & & 8.920 & & 8.717 & 8.864 & 0.203 & 3.89 & 33.4\end{array}$

Run $2828 \%$ Carbon Tetrachloride-Benzene in Water

\begin{tabular}{llllllllll}
\hline 0.25 & 3.58 & $\mathrm{D}$ & 9.340 & 0.20 & 8.785 & 9.140 & 0.555 & 2.80 & 24.0 \\
& 4.15 & & 9.340 & & 8.87 & 9.140 & 0.470 & 2.97 & 27.4 \\
& 5.37 & & 9.342 & & 8.992 & 9.142 & 0.350 & 3.26 & 31.3 \\
& 7.00 & & 9.340 & & 9.07 & 9.142 & 0.270 & 3.52 & 34.2 \\
\hline
\end{tabular}

a Data are for $50 \% 0 / W$ dispersions at $25 \mathrm{C}$.

b H - RCA 1P41 Phototube 2404 Filter $1.5 \mathrm{~cm}$ Gap Light Source as shown in Figure 4 .

D - RCA 1P41 Phototube 2404 Filter $1.5 \mathrm{~cm}$ Gap Light Source: Collimated through $18 \mathrm{~mm}$ aperture.

c $I_{0}=$ Dark Current - Zero Reading; Zero taken in clear field phase.

d $I=$ Dark Current - Measured Current. 
Table 8. Light Transmittance Data Obtained in $12^{\text {"1 }}$ Tank ${ }^{\text {* }}$

\begin{tabular}{|c|c|c|c|c|c|c|c|c|c|c|}
\hline \multicolumn{2}{|c|}{ Impeller } & \multirow{2}{*}{\multicolumn{4}{|c|}{ Probe }} & \multirow[b]{3}{*}{$\mathbb{I}_{0}^{c}$} & \multirow[b]{3}{*}{$I^{d}$} & \multirow[b]{3}{*}{$\ln \frac{I_{0}}{I}$} & \multirow{2}{*}{\multicolumn{2}{|c|}{$\begin{array}{c}\text { Interfacial } \\
\text { Area, }\end{array}$}} \\
\hline$\overline{\text { Diam }}$ & Rev & & & & & & & & & \\
\hline $\mathrm{D}$ & $\sec ^{-1}$ & $\begin{array}{l}\text { Assem- } \\
\text { bly }\end{array}$ & $\begin{array}{c}\text { Dark } \\
\text { Current }\end{array}$ & $\begin{array}{c}\text { Zero } \\
\text { Reading }\end{array}$ & $\begin{array}{c}\text { Measured } \\
\text { Current }\end{array}$ & & & & $\mathrm{cu}$ & $\mathrm{cm} / \mathrm{sq} \mathrm{cm}$ \\
\hline \multicolumn{2}{|c|}{ Run 1121} & \multicolumn{2}{|c|}{ Hexone in Water } & & & & & & & \\
\hline 0.25 & $\begin{array}{l}10.4 \\
15.5 \\
20.5\end{array}$ & $\mathrm{~B}$ & 8.969 & 0.268 & $\begin{array}{l}7.981 \\
8.447 \\
8.596\end{array}$ & 8.701 & $\begin{array}{l}0.988 \\
0.522 \\
0.373\end{array}$ & $\begin{array}{l}2.19 \\
2.82 \\
3.15\end{array}$ & & $\begin{array}{l}41.3 \\
54.2 \\
62.7\end{array}$ \\
\hline 0.33 & $\begin{array}{c}5.25 \\
6.7 \\
8.33 \\
10.4 \\
15.5\end{array}$ & & 8.969 & 0.301 & $\begin{array}{l}7.803 \\
8.275 \\
8.451 \\
8.575 \\
8.706\end{array}$ & 8.668 & $\begin{array}{l}1.166 \\
0.694 \\
0.518 \\
0.394 \\
0.263\end{array}$ & $\begin{array}{l}2.01 \\
2.53 \\
2.82 \\
3.09 \\
3.50\end{array}$ & & $\begin{array}{l}38.0 \\
48.1 \\
54.2 \\
61.1 \\
72.3\end{array}$ \\
\hline 0.50 & $\begin{array}{l}2.76 \\
3.2 \\
4.7 \\
5.35 \\
6.8\end{array}$ & & 8.969 & 0.343 & $\begin{array}{l}8.093 \\
8.371 \\
8.623 \\
8.672 \\
8.753\end{array}$ & 8.626 & $\begin{array}{l}0.876 \\
0.598 \\
0.346 \\
0.297 \\
0.216\end{array}$ & $\begin{array}{l}2.29 \\
2.67 \\
3.22 \\
3.37 \\
3.69\end{array}$ & & $\begin{array}{l}43.4 \\
51.1 \\
64.3 \\
68.9 \\
78.2\end{array}$ \\
\hline \multicolumn{2}{|c|}{ Run 1028} & \multicolumn{2}{|c|}{ Amsco in Water } & & & & & & & \\
\hline 0.25 & $\begin{array}{r}8.3 \\
10.3\end{array}$ & $\mathrm{~B}$ & 8.970 & 0.215 & $\begin{array}{l}8.859 \\
8.902\end{array}$ & 8.755 & $\begin{array}{l}0.111 \\
0.068\end{array}$ & $\begin{array}{l}4.37 \\
4.86\end{array}$ & & $\begin{array}{l}63.3 \\
77.7\end{array}$ \\
\hline 0.333 & $\begin{array}{l}5.6 \\
6.8\end{array}$ & & 8.950 & 0.267 & $\begin{array}{l}8.842 \\
8.893\end{array}$ & 8.683 & $\begin{array}{l}0.108 \\
0.057\end{array}$ & $\begin{array}{l}4.39 \\
5.03\end{array}$ & & $\begin{array}{l}63.8 \\
81.4\end{array}$ \\
\hline 0.50 & $\begin{array}{l}2.38 \\
3.22 \\
3.82\end{array}$ & & $\begin{array}{l}8.950 \\
8.950 \\
8.952\end{array}$ & 0.168 & $\begin{array}{l}8.758 \\
8.872 \\
8.883\end{array}$ & $\begin{array}{l}8.782 \\
8.782 \\
8.784\end{array}$ & $\begin{array}{l}0.192 \\
0.078 \\
0.069\end{array}$ & $\begin{array}{l}3.82 \\
4.72 \\
4.85\end{array}$ & & $\begin{array}{l}51.2 \\
72.7 \\
76.2\end{array}$ \\
\hline 0.667 & $\begin{array}{l}1.55 \\
1.95 \\
2.70\end{array}$ & 。 & $\begin{array}{l}8.950 \\
8.950 \\
8.955\end{array}$ & 0.152 & $\begin{array}{l}8.753 \\
8.826 \\
8.902\end{array}$ & $\begin{array}{l}8.798 \\
8.798 \\
8.803\end{array}$ & $\begin{array}{l}0.197 \\
0.124 \\
0.053\end{array}$ & $\begin{array}{l}3.80 \\
4.26 \\
5.12\end{array}$ & & $\begin{array}{l}50.7 \\
60.7 \\
84.1\end{array}$ \\
\hline Run 11 & & Xylene in & Water & & & & & & & \\
\hline 0.25 & $\begin{array}{l}10.4 \\
15.5 \\
20.5\end{array}$ & $\mathrm{~B}$ & 9.000 & 0.306 & $\begin{array}{l}8.727 \\
8.841 \\
8.882\end{array}$ & 8.694 & $\begin{array}{l}0.273 \\
0.159 \\
0.118\end{array}$ & $\begin{array}{l}3.46 \\
4.01 \\
4.30\end{array}$ & & $\begin{array}{l}28.4 \\
35.6 \\
39.7\end{array}$ \\
\hline 0.333 & $\begin{array}{c}5.33 \\
6.8 \\
8.5 \\
10.7\end{array}$ & & 9.000 & 0.309 & $\begin{array}{l}8.605 \\
8.742 \\
8.802 \\
8.846\end{array}$ & 8.691 & $\begin{array}{l}0.395 \\
0.258 \\
0.198 \\
0.154\end{array}$ & $\begin{array}{l}3.09 \\
3.46 \\
3.72 \\
4.03\end{array}$ & & $\begin{array}{l}24.5 \\
28.4 \\
31.8 \\
36.0\end{array}$ \\
\hline
\end{tabular}

- Lower case superscripts refer to footnotes on page 90. 
Table $8(\text { Continued })^{a}$

\begin{tabular}{|c|c|c|c|c|c|c|c|c|c|c|}
\hline \multicolumn{2}{|c|}{ Impeller } & \multirow{2}{*}{\multicolumn{4}{|c|}{ Probe }} & \multirow[b]{3}{*}{$\mathbb{I}_{0}^{c}$} & \multirow[b]{3}{*}{$I^{d}$} & \multirow[b]{3}{*}{$\ln \frac{I_{0}}{I}$} & \multirow{2}{*}{\multicolumn{2}{|c|}{$\begin{array}{c}\text { Interfacial } \\
\text { Area }\end{array}$}} \\
\hline$\overline{\mathrm{Di} \text { am }}$ & Rev & & & & & & & & & \\
\hline $\begin{array}{l}D \\
f t\end{array}$ & $\sec ^{-1}$ & $\begin{array}{c}\text { Assem- } \\
\text { bly b }\end{array}$ & $\begin{array}{c}\text { Dark } \\
\text { Current }\end{array}$ & $\begin{array}{c}\text { Zero } \\
\text { Reading }\end{array}$ & $\begin{array}{c}\text { Measured } \\
\text { Current }\end{array}$ & & & & & $\mathrm{cm} / \mathrm{sq} \mathrm{cm}$ \\
\hline \multicolumn{2}{|c|}{ Run 119} & \multicolumn{3}{|c|}{ Xylene in Water (Continued) } & & & & & & \\
\hline 0.50 & $\begin{array}{l}2.85 \\
3.67 \\
4.75 \\
5.4\end{array}$ & & 9.000 & 0.217 & $\begin{array}{l}8.648 \\
8.754 \\
8.841 \\
8.841\end{array}$ & 8.783 & $\begin{array}{l}0.352 \\
0.246 \\
0.159 \\
0.159\end{array}$ & $\begin{array}{l}3.22 \\
3.57 \\
4.01 \\
4.01\end{array}$ & & $\begin{array}{l}25.8 \\
29.3 \\
35.6 \\
35.6\end{array}$ \\
\hline 0.667 & $\begin{array}{l}2.04 \\
2.8 \\
3.04\end{array}$ & & 9.000 & 0.302 & $\begin{array}{l}8.684 \\
8.803 \\
8.851\end{array}$ & 8.698 & $\begin{array}{l}0.316 \\
0.197 \\
0.149\end{array}$ & $\begin{array}{l}3.31 \\
3.79 \\
4.07\end{array}$ & & $\begin{array}{l}26.8 \\
32.6 \\
36.3\end{array}$ \\
\hline \multicolumn{2}{|c|}{ Run 1128} & Isobutanol & in Wate & & & & & & & \\
\hline 0.25 & $\begin{array}{l}8.45 \\
10.5 \\
15.7 \\
20.6\end{array}$ & $\mathrm{~B}$ & 8.972 & 0.148 & $\begin{array}{l}8.557 \\
8.672 \\
8.812 \\
8.865\end{array}$ & 8.824 & $\begin{array}{l}0.415 \\
0.300 \\
0.160 \\
0.107\end{array}$ & $\begin{array}{l}3.06 \\
3.38 \\
4.01 \\
4.42\end{array}$ & & $\begin{array}{r}76.2 \\
87.4 \\
112.4 \\
131.5\end{array}$ \\
\hline 0.333 & $\begin{array}{l}4.7 \\
5.33 \\
6.8 \\
8.45 \\
10.6\end{array}$ & & 8.972 & 0.151 & $\begin{array}{l}8.532 \\
8.635 \\
8.744 \\
8.803 \\
8.848\end{array}$ & 8.821 & $\begin{array}{l}0.440 \\
0.337 \\
0.228 \\
0.169 \\
0.124\end{array}$ & $\begin{array}{l}2.99 \\
3.27 \\
3.66 \\
3.96 \\
4.26\end{array}$ & & $\begin{array}{r}74.3 \\
83.3 \\
97.1 \\
110.5 \\
123.3\end{array}$ \\
\hline 0.50 & $\begin{array}{l}2.0 \\
2.7 \\
3.2 \\
4.8 \\
5.4\end{array}$ & & 8.972 & 0.332 & $\begin{array}{l}8.493 \\
8.687 \\
8.761 \\
8.852 \\
8.873\end{array}$ & 8.640 & $\begin{array}{l}0.479 \\
0.285 \\
0.211 \\
0.120 \\
0.099\end{array}$ & $\begin{array}{l}2.89 \\
3.42 \\
3.70 \\
4.28 \\
4.47\end{array}$ & & $\begin{array}{r}71.0 \\
88.4 \\
99.1 \\
124.6 \\
133.0\end{array}$ \\
\hline 0.667 & $\begin{array}{l}1.37 \\
2.1 \\
2.9 \\
3.2 \\
3.6\end{array}$ & & $\begin{array}{l}8.965 \\
8.968 \\
8.972 \\
8.980 \\
8.970\end{array}$ & 0.281 & $\begin{array}{l}8.559 \\
8.772 \\
8.853 \\
8.887 \\
8.897\end{array}$ & $\begin{array}{l}8.684 \\
8.687 \\
8.691 \\
8.699 \\
8.689\end{array}$ & $\begin{array}{l}0.406 \\
0.196 \\
0.119 \\
0.093 \\
0.073\end{array}$ & $\begin{array}{l}3.06 \\
3.79 \\
4.29 \\
4.58 \\
4.70\end{array}$ & & $\begin{array}{r}76.2 \\
102.7 \\
125.3 \\
140.0 \\
146.9\end{array}$ \\
\hline
\end{tabular}

a Data are for $50 \% \mathrm{O} / \mathrm{W}$ dispersions at $25 \mathrm{C}$.

b B - RCA 1P41 Phototube 2404 Filter $1.5 \mathrm{~cm}$ Gap Light Source as shown in Figure 4.

D - RCA IP41 Phototube 2404 Filter $1.5 \mathrm{~cm}$ Gap Light Source: Collimated through $18 \mathrm{~mm}$ aperture.

c $\mathbf{I}_{0}=$ Dark Current - Zero Reading; Zero taken in clear field phase.

d $I=$ Dark Current - Measured Current. 
Table 9. Light Transmittance Data Obtained in 18" Tank ${ }^{\text {* }}$

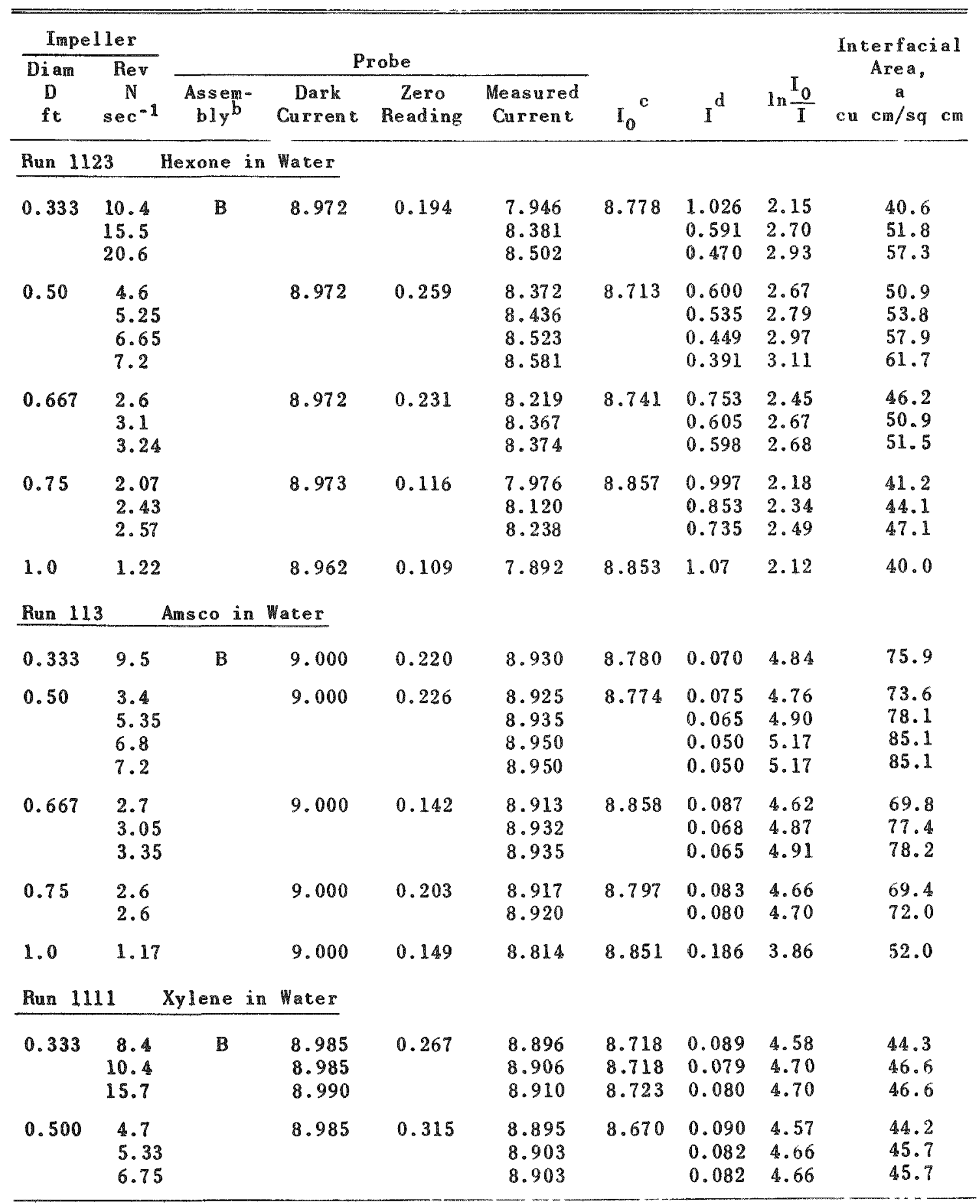

- Lower case superscripts refer to footnotes on page 92. 
Table $9{\text { (Continued })^{a}}^{a}$

\begin{tabular}{|c|c|c|c|c|c|c|c|c|c|}
\hline \multicolumn{2}{|c|}{ Impeller } & \multirow{2}{*}{\multicolumn{4}{|c|}{ Probe }} & \multirow[b]{3}{*}{$\mathbb{I}_{0}^{c}$} & \multirow[b]{3}{*}{$I^{d}$} & \multirow[b]{3}{*}{$\ln \frac{10}{1}$} & \multirow{3}{*}{$\begin{array}{c}\text { Interfacial } \\
\text { Area } \\
\text { cu } \mathrm{cm} / \mathrm{sq} \mathrm{cm}\end{array}$} \\
\hline Diam & $\overline{\operatorname{Rev}}$ & & & & & & & & \\
\hline $\begin{array}{l}\mathrm{D} \\
\mathrm{ft}\end{array}$ & $\sec ^{-1}$ & $\begin{array}{l}\text { Assem- } \\
\text { bly }\end{array}$ & $\begin{array}{c}\text { Dark } \\
\text { Current }\end{array}$ & $\begin{array}{l}\text { Zero } \\
\text { Reading }\end{array}$ & $\begin{array}{l}\text { Mesured } \\
\text { Current }\end{array}$ & & & & \\
\hline \multicolumn{2}{|c|}{ Run 1111} & Xylene in & \multicolumn{2}{|c|}{ Water (Continued) } & & & & & \\
\hline 0.667 & $\begin{array}{l}2.04 \\
2.83 \\
3.07\end{array}$ & & 9.000 & 0.256 & $\begin{array}{l}8.887 \\
8.913 \\
8.913\end{array}$ & 8.744 & $\begin{array}{l}0.113 \\
0.087 \\
0.087\end{array}$ & $\begin{array}{l}4.35 \\
4.60 \\
4.60\end{array}$ & $\begin{array}{l}40.4 \\
4.4 .6 \\
44.6\end{array}$ \\
\hline 0.750 & $\begin{array}{l}2.0 \\
2.4 \\
2.47\end{array}$ & & 9.000 & 0.142 & $\begin{array}{l}8.896 \\
8.915 \\
8.915\end{array}$ & 8.858 & $\begin{array}{l}0.104 \\
0.085 \\
0.085\end{array}$ & $\begin{array}{l}4.44 \\
4.65 \\
4.65\end{array}$ & $\begin{array}{l}42.0 \\
45.7 \\
45.7\end{array}$ \\
\hline 1.0 & $\begin{array}{l}1.17 \\
1.20 \\
1.20\end{array}$ & & 9.000 & 0.159 & $\begin{array}{l}8.851 \\
8.873 \\
8.873\end{array}$ & 8.841 & $\begin{array}{l}0.149 \\
0.127 \\
0.127\end{array}$ & $\begin{array}{l}4.09 \\
4.25 \\
4.25\end{array}$ & $\begin{array}{l}36.6 \\
38.9 \\
38.9\end{array}$ \\
\hline Run 11 & & Isobutanol & in Wate & & & & & & \\
\hline 0.333 & $\begin{array}{r}8.4 \\
10.4 \\
15.7 \\
20.6\end{array}$ & B & 8.972 & 0.323 & $\begin{array}{l}8.652 \\
8.732 \\
8.862 \\
8.892\end{array}$ & 8.649 & $\begin{array}{l}0.320 \\
0.240 \\
0.110 \\
0.080\end{array}$ & $\begin{array}{l}3.30 \\
3.58 \\
4.36 \\
4.69\end{array}$ & $\begin{array}{l}83.2 \\
93.3 \\
124 \\
142\end{array}$ \\
\hline 0.500 & $\begin{array}{l}3.2 \\
4.8 \\
5.4 \\
6.75 \\
7.05\end{array}$ & $\mathrm{~B}$ & 8.972 & 0.287 & $\begin{array}{l}8.677 \\
8.803 \\
8.826 \\
8.868 \\
8.868\end{array}$ & 8.685 & $\begin{array}{l}0.295 \\
0.169 \\
0.146 \\
0.104 \\
0.104\end{array}$ & $\begin{array}{l}3.38 \\
3.94 \\
4.08 \\
4.42 \\
4.42\end{array}$ & $\begin{array}{l}86.0 \\
108 \\
113 \\
130 \\
130\end{array}$ \\
\hline 0.667 & $\begin{array}{l}1.95 \\
2.6 \\
3.15\end{array}$ & & 8.985 & 0.231 & $\begin{array}{l}8.678 \\
8.783 \\
8.837\end{array}$ & 8.754 & $\begin{array}{l}0.307 \\
0.202 \\
0.148\end{array}$ & $\begin{array}{l}3.35 \\
3.73 \\
4.08\end{array}$ & $\begin{array}{l}85.1 \\
98.8 \\
113\end{array}$ \\
\hline 0.75 & $\begin{array}{l}1.28 \\
1.9 \\
2.4\end{array}$ & & 8.985 & 0.197 & $\begin{array}{l}8.583 \\
8.757 \\
8.832\end{array}$ & 8.788 & $\begin{array}{l}0.402 \\
0.228 \\
0.153\end{array}$ & $\begin{array}{l}3.09 \\
3.65 \\
4.05\end{array}$ & $\begin{array}{l}76.4 \\
96.0 \\
112\end{array}$ \\
\hline 1.0 & $\begin{array}{l}1.07 \\
1.18 \\
1.20\end{array}$ & & 8.985 & 0.219 & $\begin{array}{l}8.736 \\
8.771 \\
8.771\end{array}$ & 8.766 & $\begin{array}{l}0.249 \\
0.214 \\
0.214\end{array}$ & $\begin{array}{l}3.56 \\
3.71 \\
3.71\end{array}$ & $\begin{array}{l}92.4 \\
98.4 \\
98.4\end{array}$ \\
\hline
\end{tabular}

Data are for $50 \% 0 /$ dispersions $25 \mathrm{C}$.

b B - RCA 1PA1 Phototube 2404 Filter $1.5 \mathrm{~cm}$ Gap Light Source as shown in Figure 4 .

D - RCA 1P41 Phototube 2404 Filter $1.5 \mathrm{~cm}$ Gap Light Source: Collimated chrough $18 \mathrm{~mm}$ aperture

c $I_{0}=$ Dark Current - Zero Reading; Zero taken in clear field phase.

d I = Dark Current - Measured Current. 
APPENDIX III
PARAMET ERS USED IN CORRELATION 
Table 10. Parameters Used in Correlation

\begin{tabular}{|c|c|c|c|c|c|c|c|c|c|c|}
\hline Run & System $^{a}$ & $\begin{array}{c}\text { Relative } \\
\text { Pef. Index } \\
\eta_{\mathrm{D}} / \eta_{\mathrm{F}} \\
\mathrm{m}\end{array}$ & $\begin{array}{c}\text { Lorentzb } \\
\text { Coeff. } \\
M\end{array}$ & $\begin{array}{c}\operatorname{Ligh} L^{c} \\
\operatorname{Tran} . \\
\text { Coeff. } \\
a\end{array}$ & $\begin{array}{l}\text { Pertinent } \\
\text { Area-Light } \\
\text { Correlation }\end{array}$ & $\frac{\Delta \rho}{\rho_{\mathrm{F}}}$ & $\exp$ & {$\left[3.6 \frac{\Delta \rho}{\rho_{\mathrm{T}}}\right]$} & $\frac{v_{\mathrm{D}}}{v_{\mathrm{F}}}$ & $\left(\frac{\nu_{0}}{\nu_{\mathrm{F}}}\right)^{1 / 5}$ \\
\hline 922 & Cyclohexane & 1.053 & 0.042 & 0.052 & $\mathrm{~B}$ & 0.237 & & 2.35 & 1.12 & 1.023 \\
\hline 31 & Amsco & - & - & - & - & 0.222 & & 2.22 & 1.57 & 1.095 \\
\hline 628 & Amscof & 1.075 & 0.049 & 0.06 & B & 0.227 & & 2.20 & 1.48 & 1.08 \\
\hline $\begin{array}{r}1028 \\
113\end{array}$ & Amscof ${ }^{f}$ & 1.076 & 0.05 & 0.061 & B & 0.223 & & 2.23 & 1.59 & 1.081 \\
\hline $\begin{array}{r}119 \\
1111\end{array}$ & Xylene & 1.1211 & 0.079 & 0.095 & B & 0.137 & & 1.635 & 0.79 & 0.955 \\
\hline 23 & Xylene & 1.1211 & 0.079 & 0.09 & D & 0.138 & & 1.64 & 0.79 & 0.955 \\
\hline 29 & $\begin{array}{l}5 \% \text { White Oil } \\
\text { in Xylene }\end{array}$ & 1.1191 & 0.0776 & 0.087 & $\mathrm{D}$ & 0.138 & & 1.64 & 0.88 & 0.975 \\
\hline 214 & $\begin{array}{l}28 \% \text { Whi te Oil } \\
\text { in Xylene }\end{array}$ & 1.1170 & 0.0763 & 0.080 & D & 0.134 & & 1.615 & 1.56 & 1.093 \\
\hline 224 & $\begin{array}{l}\text { 61\% Whice Oil } \\
\text { in Xylene }\end{array}$ & 1.1125 & 0.0734 & 0.083 & $\mathrm{D}$ & 0.127 & & 1.575 & 9.55 & 1.57 \\
\hline 314 & Benzene & 1.1232 & 0.0802 & 0.09 & D & 0.125 & & 1.56 & 0.77 & 0.95 \\
\hline 216 & Hexone & 1.0445 & 0.0294 & 0.038 & $\mathrm{D}$ & 0.196 & & 2.02 & 0.78 & 0.95 \\
\hline $\begin{array}{l}1121 \\
1123\end{array}$ & Hexone & 1.045 & 0.0298 & 0.038 & $B$ & 0.195 & & 2.01 & 0.79 & 0.955 \\
\hline 75 & $\begin{array}{c}20 \% \mathrm{CCl}_{4} \text { in } \\
\text { Benzene }\end{array}$ & - & - & - & - & 0.0176 & & 1.065 & 0.72 & 0.935 \\
\hline 727 & $\underset{\text { Benzene }}{11 \% \mathrm{CCI}_{4}}$ in & 1.1242 & 0.0808 & 0.098 & $B$ & 0.039 & & 1.15 & 0.74 & 0.94 \\
\hline 728 & $\begin{array}{c}25 \% \mathrm{CCl}_{4} \text { in } \\
\text { Benzene }\end{array}$ & 1.116 & 0.0766 & 0.092 & $\mathrm{~B}$ & 0.041 & & 1.16 & 0.74 & 0.94 \\
\hline 28 & $\underset{\text { Benzene }}{28 \% \mathrm{CCl}_{4}}$ in & 1.1146 & 0.0747 & 0.085 & D & 0.078 & & 1.32 & 0.72 & 0.935 \\
\hline 927 & Chlorobenzene & 1.142 & 0.092 & 0.112 & B & 0.105 & & 1.45 & 0.78 & 0.95 \\
\hline 730 & Isobutanol & 1.036 & 0.024 & 0.0315 & 13 & 0.150 & & 1.70 & 2.06 & 1.155 \\
\hline $\begin{array}{l}1128 \\
1130\end{array}$ & Isobutanol & 1.034 & 0.023 & 0.0305 & B & 0.154 & & 1.73 & 2.84 & 1.23 \\
\hline 810 & Isoamyl Alcohol & 1.0487 & 0.0322 & 0.041 & B & 0.169 & & 1.83 & 4.27 & 1.34 \\
\hline 128 & $\begin{array}{l}\text { Iributyl } \\
\text { Phosphate }\end{array}$ & - & - & - & - & 0.0182 & & 1.068 & 4.45 & 1.35 \\
\hline
\end{tabular}

a Dispersed phase - continuous phase distilled water in each case.

b Correlating parameter for Area-Ligh Transmission $=\begin{aligned} & m^{2}-1 \\ & m^{2}+2\end{aligned}$

c Corelating parameter found from ligures 13 and 14 and used in Figures 11 and 12 .

d $B$ refers to Figures 12 and $14 ; D$ refers to 1 pures 11 and 13 .

e A kerosene as received from Central Solvents and Chemicals Co., Chicago, 111.

f Same kerosene prewashed with caustic and water and then distilled.

g Methyl Isobutyl Ketone. 
APPENDIX IV

EFFECT OF CONTAMINATION 
Table 11. Data Illustrative of Effect of Contamination on Settling Time and Interfacial Area

\begin{tabular}{|c|c|c|c|c|}
\hline \multicolumn{2}{|c|}{ Impeller } & & \multirow{2}{*}{$\begin{array}{l}\text { Settling } \\
\text { Time }\end{array}$} & \multirow{2}{*}{$\begin{array}{c}\text { Interfacial } \\
\text { Tension }\end{array}$} \\
\hline$\overline{\text { Diam }}$ & & & & \\
\hline $\begin{array}{l}D \\
f t\end{array}$ & $\begin{array}{c}N \\
\sec ^{-1}\end{array}$ & $\underset{\mathrm{cm}^{-1}}{\mathrm{a}}$ & $\stackrel{t}{t}$ & $\sigma_{\dot{i}}$ \\
\hline $\operatorname{Run} 914$ & Hexone in Water & & & \\
\hline \multirow[t]{3}{*}{0.25} & 4.38 & 38.6 & 0.19 & - \\
\hline & & 44.0 & 0.36 & - \\
\hline & & 49.3 & 0.78 & - \\
\hline Run 31 & Ansco (untreated) & in Water & & \\
\hline 0.25 & 4.38 & 51.8 & 1.47 & 44.1 \\
\hline Run 628 & Amsco (treated) in & Water & & \\
\hline 0.25 & 4.38 & 37.5 & 0.39 & 44.1 \\
\hline
\end{tabular}




\section{BIBLIOGRAPHY}

1. Bailey, E. D., Ind. Eng. Chem. (ANAL) 18, 365, (1946).

2. Bernstein, I., Unpublished Senior Project Report, Illinois Institute of Technology (1950).

3. Boll, R. H., R. O. Gumprecht, and C. M. Sliepcevich. J. Optical Soc., 44, 18 (1954).

4. Christian, W. J., Unpublished M. S. Thesis, Mllinois Institute of Technology, (1953).

5. Clark, N. O., and M. Blackman, Trans. Faraday Soc., 44, 1, 7 (1948).

6. Clay, P.H., Proc. Royal Acad. Sci., Amsterdam, 43, 852, 979 (1940).

7. Flynn, K. F., Unpublished Senior Project Report, Illinois Institute of Technology (1952).

8. Glasstone, S., Textbook of Physical Chemistry, D. Van Nostrand Co., Inc., New York, 2nd Edition (1946).

9. Gumprecht, R, O., and C. M. Sliepcevich, Tables of Light Scattering Functions for Spherical Particles, Univ. of Mich. Eng. Research Inst., Special Publication, Ann Arbor, Michigan (1951).

10. Gumprecht, R. O. and C. M. Sliepcevich, J. Phys. Chem., 57, 90 (1953).

11. Gumprecht, R, O. and C.M. Sliepcevich, J. Phys. Chem.: 57, 95 (1953).

12. Harkins, W. D., The Physical Chemistry of Surface Films, Reinhold Publishing Co., New York, New York, page 78.

13. Hernandez-Fragoso, J., Unpublished M.S. Thesis, Illinois Institute of Technology, (1950).

14. Hinze, J. O., "Fundamentals of the Hydrodynamic Mechanism of Splitting Up in Dispersion Processes" presented at December, 1954 meeting of $\mathrm{AIChE}$. 
15. Kessie, R. W., Unpublished M.S. Thesis, Illinois Institute of Technology, (1955).

16. LaMer, V. K., and D. Sinclair, OSRD Reports 1857 and 944, Office of Publications Board, U.S. Department of Commerce.

17. Langhaar, H. L., Dimensionless Analyses and Theory of Models, John Wiley, New York (1951).

18. Langlois, G. E., Unpublished Thesis, Graduate School, Univ. of Calif. (1.952).

19. Langlois, G. E., J. E. Gulberg, T. Vermeulen, Chem. Eng. Prog., 51, 81 F (1955)。

20. Langlois, G. E., G. M. Williams, and T. Vermeulen, Chem. Eng. Prog., 51, 81 F (1955).

21. Lewis, W. C. McC., Kolloid-Z, $\underline{5}, 91$ (1909).

22. Oldshue, J。Y., Unpublished Ph.D. Thesis, Illinois Institute of Technology, (1950).

23. Rayleigh, Phil Mag. (5), 47, 375 (1899).

24. Rose, H. E., and C. J. French, J. Soc. Chem. Ind., 67, 283 (1948).

25. Roy, P. H. Unpublished Ph.D. Thesis, Illinois Institute of Technology (1955).

26. Roy, P. H. and J. H. Rushton, "Effect of Turbulence on Drop Size for an Oil-Water Dispersion" presented at November, 1955 meeting of AIChE.

27. Rushton, J. H. , Canadian Chemistry and Process Industries, May, 1946.

28. Rushton, J.H., E. W. Costich, and H. J. Everett, "Power Characteristics of Mixing Impellers," Chem. Eng. Prog. $46,8,395,(1950)$.

29. Sinclair, D. and V. K. LaMer, Chem, Rev, 44, 245 (1949).

30. Stamm, A. J. and T. Svedberg, I. Am. Chem. Soc., 47, 1582 (1925). 
31. Taylor, G. I., Proc. Roy Soc., 146A, 501 (1934).

32. Taylor, J。F, , H. L. Grimmett, E. W. Comings, Chem. Eng. Prog., 47, 4, 175 (1951).

33. Tomotika, S., Proc. Roy Soc., 150A, 322 (1935).

34. Tomotika, S., Proc.Roy Soc., 153A, 302 (1936).

35. Trice, V. G, Jr., and W. A. Rodger "Light Transmission as a Measure of Interfacial Area in Liquid-Liquid Dispersions," ANL-5512.

36. Trice, V. G., Jr., and W. A. Rodger, "Light Transmission as a Measure of Interfacial Area in Liquid-Liquid Dispersions," J.A.I.Ch.E。 in press.

37. Van Den Tempel, M., Rubber-Stichtling Communication No. 225 Delft (1953). 